\title{
INVESTIGATION OF THERMAL STORAGE AND STEAM GENERATOR ISSUES
}

\section{Bechtel Corporation}

50 Beale St.

San Francisco, CA 94119

Sandia Contract 87-5142

\begin{abstract}
A review and evaluation of steam generator and thermal storage tank designs for commercial nitrate salt technology showed that the potential exists to procure both on a competitive basis from a number of qualified vendors. The report outlines the criteria for review and the results of the review, which was intended only to assess the feasibility of each design, not to make a comparison or select the best concept.
\end{abstract}

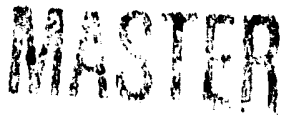




\section{Contents}

$\underline{\text { Section }} \quad \underline{\text { Page }}$

1 Executive Summary $1-1$

Background $1-1$

Investigation of Thermal Storage and Steam Generator Issues $\quad 1-1$

Conclusions $1-4$

Future Activities $\quad 1-6$

2 Background and Introduction $\quad 2-1$

Utility Studies Phase I Steam Generator and Thermal Storage Tank Designs $2-1$

Utility Studies Phase II Steam Generator and Thermal Storage Tank Designs $\quad 2-2$

Investigation of Thermal Storage and Steam Generator Issues $\quad 2-2$

3 Steam Generator Designs and Cost Estimates 3-1

Specification $\quad 3-1$

Design Features $3-1$

ABB Lummus Kettle Boiler Steam Generator $\quad 3-7$

Struthers Wells Kettle Boiler Steam Generator $3-9$

Foster Wheeler Straight Tube Steam Generator 3-9

B\&W / SAIC U-tube/U-shell Steam Generator $\quad 3-12$

$\begin{array}{lr}\text { Vessel Shell Thicknesses and Weights } & 3-15\end{array}$

$\begin{array}{lr}\text { Startup Times } & 3-16\end{array}$

Advantages and Disadvantages $3-18$

Warranty Provisions $\quad 3-19$

Capital Cost Estimates $\quad 3-20$

Design, Procurement, and Installation Cost Estimates $\quad 3-20$

$\begin{array}{ll}\text { Operating Cost Estimates } & 3-24\end{array}$

Design, Procurement, Installation, and Operating Cost Estimates $\quad 3-26$

4 Thermal Storage System Hot Salt Tank Designs and Cost Estimates 4-1

Specification $4-1$

Design Features $\quad$ 4-3

Externally Insulated Tanks 4-3

Internally Insulated Tank 4-11

Thermal Losses and Transient Performance 4-13

Leak Repair Times $\quad$ 4-14

Advantages and Disadvantages $\quad 4-15$

Warranty Provisions $\quad 4-17$

Capital Cost Estimates $\quad$ 4-17

Design, Procurement, and Installation Cost Estimates 4-17

Operating Cost Estimates $\quad$ 4-22

Design, Procurement, Installation, and Operating Cost Estimates 4-23

5 References $5-1$ 


\section{Contents (Continued)}

\section{Appendices}

Page

A Statement of Work for Steam Generator Vendors

B Statement of Work for Thermal Storage System Hot Salt Tank Vendors

A-1

B-1 


\section{Tables}

Table

Page

1-1 Steam Generator Designs and Cost Estimates

1-2 Thermal Storage Hot Salt Tank Designs and Cost Estimates

3-1 Steam Generator Performance Specification

3-2 Comparison of Steam Generator Technical Characteristics

3-3 Comparison of Steam Generator Vessel Shell Thicknesses and Weights

3-4 Startup Times from Cold and Warm Conditions

3-5 Heat Exchanger Concept Advantages and Disadvantages

3-6 Comparison of Steam Generator Warranty Provisions

3-7 Comparison of Steam Generator Cost Estimates

3-8 Comparison of Heat Exchanger Unit Costs

4-1 Hot Salt Tank Performance Specification

4-2 Comparison of Hot Salt Tank Technical Characteristics

4-3 Comparison of Hot Salt Tank Thermal Losses

4-4 Storage Tank Concept Advantages and Disadvantages

4-5 Comparison of Hot Salt Tank Cost Estimates

$4-18$

4-6 Technigaz Hot Salt Tank Cost Estimate Details

Figures

Figure

Page

3-1 ABB Lummus Steam Generator Flow Schematic 3-8

3-2 Struthers Wells Steam Generator Flow Schematic $3-10$

3-3 Foster Wheeler Steam Generator Flow Schematic

$3-11$

3-4 B\&W / SAIC Steam Generator Flow Schematic (Salt Side)

$3-13$

3-5 B\&W / SAIC Steam Generator Flow Schematic (Water/Steam Side)

$3-14$

4-1 Chicago Bridge and Iron Hot Salt Tank Elevation Drawing

4-4

4-2 Pitt-Des Moines Hot Salt Tank Elevation Drawing

4-6

4-3 Technigaz Hot Salt Tank Elevation Drawing 


\section{Section 1 \\ Executive Summary}

\section{BACKGROUND}

In 1986, two utilities, Arizona Public Service Company (APS) and Pacific Gas and Electric Company (PG\&E), entered into a cooperative agreement with the Department of Energy to define the first generation of commercial central receiver power plants. The study, entitled "Solar Central Receiver Technology Advancement for Electric Utility Applications" (and called the "Utility Studies" for convenience), had two phases.

The goal of Phase I was to develop a consensus on the near term commercial plant design, with an emphasis on the selection of the preferred receiver (sodium or nitrate salt; cavity or external). The study concluded that a $100 \mathrm{MWe}$ plant with a cylindrical nitrate salt receiver and a surround heliostat field was the preferred commercial design (Ref. 1-1). To simplify the study, the designs of various equipment items were fixed at the beginning so as not to divert attention from the receiver optimization studies. In the thermal storage system, this included a stainless steel hot salt thermal storage tank with external insulation. In the steam generation system, a forced recirculation design with U-tube/U-shell heat exchangers was selected.

The goal of Phase II was to establish a development pian to commercialize the technology. The study concluded that the conversion of the $10 \mathrm{MWe}$ Solar One pilot plant to nitrate salt technology was the lowest cost approach to commercialize the technology (Ref. 1-2). During the study, budgetary quotes were requested from two thermal storage tank vendors and three potential steam generator vendors. Both tank vendors proposed stainless steel hot salt tanks with external insulation. However, an alternate hot salt tank design using a carbon steel shell and internal insulation was not evaluated during the study. Furthermore, two of the three heat exchanger vendors proposed kettle boiler concepts for the steam generator. Thus, there were several differences between the equipment designs for the first commercial plant and the $10 \mathrm{MWe}$ plant that was to precede it.

\section{INVESTIGATION OF THERMAL STORAGE AND STEAM GENERATOR ISSUES}

Late in 1991, Southern California Edison Company organized a group of utilities and government organizations, and submitted a proposal to DOE to convert the Solar One plant to nitrate salt technology (Solar Two). The purpose of the project was to reduce the perceived risk in building the first commercial $100 \mathrm{MWe}$ plant. To this end, Solar Two needed to duplicate the technical features of the first commercial plant as closely as possible

The question arose: What should be the steam generator and thermal storage tank designs in the first commercial plant? This study sought a partial answer by reviewing potential equipment designs and identifying those which would be feasible. The approach involved the following steps:

- Subcontracts were placed with four heat exchanger vendors to examine the full range of steam generator options, as follows: 
- ABB Lummus Heat Transfer: kettle evaporator with U-tube/straight shell heat exchangers

- Struthers Wells Corporation: kettle evaporator with U-tube/straight shell heat exchangers

- Foster Wheeler Development Corporation: natural circulation evaporator with straight tube/straight shell heat exchangers

- Babcock and Wilcox Company / Science Applications International Corporation (B\&W / SAIC): forced recirculation evaporator with U-tube/U-shell heat exchangers

The statement of work for the steam generator vendors is presented in Appendix A

- Subcontracts were placed with three thermal storage tank vendors to examine the alternate hot salt tank designs, as follows:

- Chicago Bridge and Iron Technical Services Company (CBI): stainless steel tank with external insulation

- Pitt-Des Moines, Inc. (PDM): stainless steel tank with external insulation

- S. N. Technigaz: carbon steel tank with internal refractorv insulation

Note that only hot tank designs were evaluated, because it is generally agreed that the cold tank would be fabricated from carbon steel and use external insulation. The statement of work for the tank vendors is presented in Appendix B

- The vendors developed conceptual designs and cost estimates for the equipment required in the first $100 \mathrm{MWe}$ commercial plant. Summaries of the heat exchanger and tank vendor designs and cost estimates are shown in Tables $1-1$ and $1-2$, respectively

- Bechtel reviewed the vendor information, assessed the technical feasibility of each design, and determined whether the equipment would be suitable for the commercial plant.

It should be noted that the purpose of this study was limited to a basic assessment of the feasibility of each design. The assessment addressed the following:

- Can a steam generator using a kettle evaporator be fabricated for a $100 \mathrm{MWe}$ plant?

- Will a large, flat bottom, stainless steel tank be suitable in solar power plant service?

- Are the vendors prepared to offer warranties and budgetary cost estimates?

The study was not intended as a detailed comparison of alternate designs or a selection of the best concept. For example, each steam generator will have different overnight temperature control and morning startup requirements. The influence of these requirements on annual plant performance and revenue requirements, and the selection of the preferred concept, is discussed below under liITIIRI: ACTIVITIES 
Table 1-1

STEAM GENERATOR DESIGNS AND COST ESTIMATES

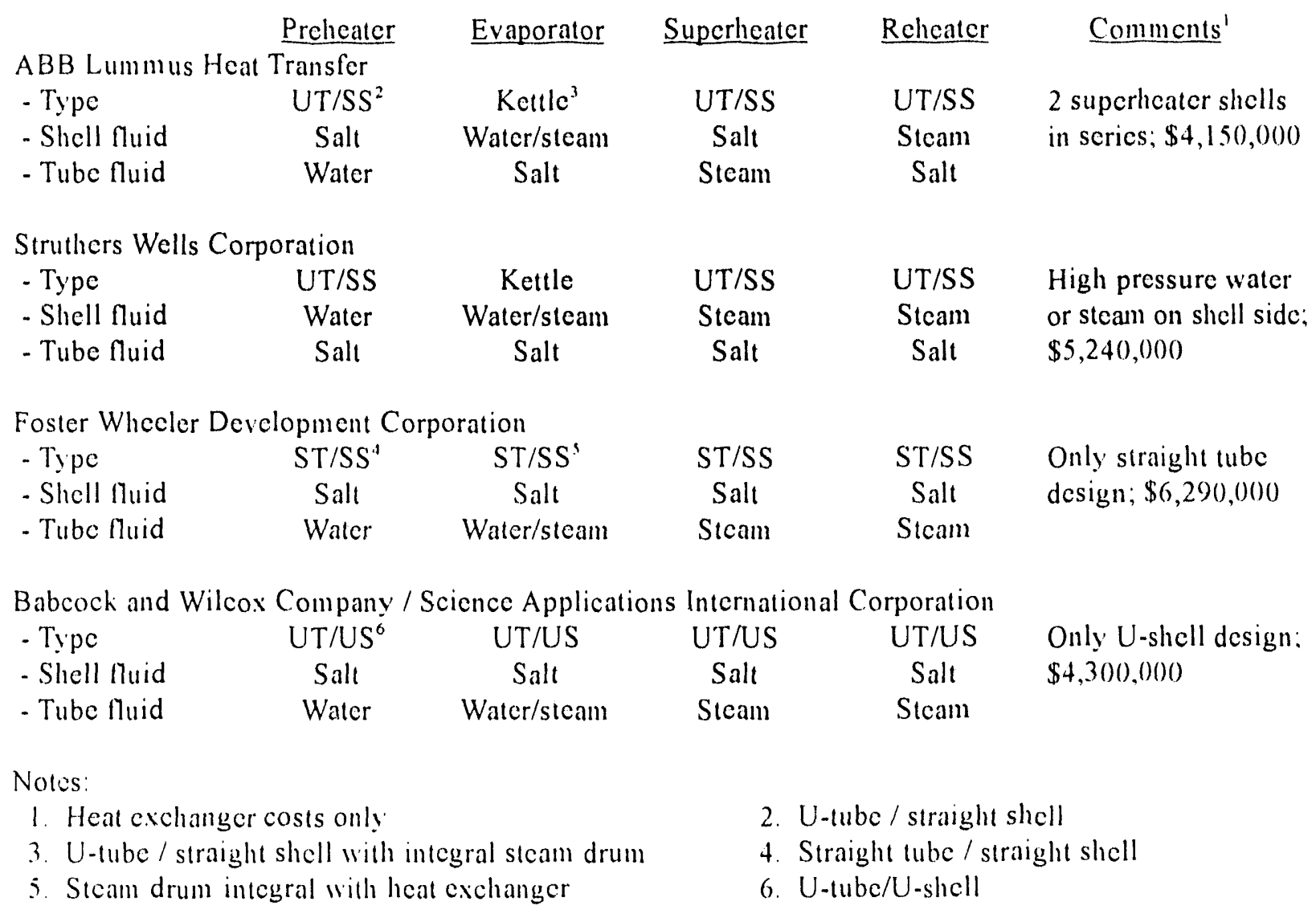

Table 1-2

THERMAL STORAGE HOT SALT TANK DESIGNS AND COST ESTIMATES

\begin{tabular}{|c|c|c|c|c|c|}
\hline Company & $\begin{array}{l}\text { Pressure } \\
\text { Boundary }\end{array}$ & $\begin{array}{l}\text { Internal } \\
\text { Liner }\end{array}$ & $\begin{array}{l}\text { Internal } \\
\text { Insulation }\end{array}$ & $\begin{array}{l}\text { Extcrnal } \\
\text { Insulation }\end{array}$ & Capital Cost' \\
\hline $\begin{array}{l}\text { Chicago } \\
\text { Bridge and Iron }\end{array}$ & $\begin{array}{l}\text { Stainless } \\
\text { sted }\end{array}$ & None & Nonc & $\begin{array}{c}\text { Mineral } \\
\text { wool }\end{array}$ & $\$ 3,7(00,(0)(0)$ \\
\hline $\begin{array}{l}\text { Pill-Des } \\
\text { Moincs }\end{array}$ & $\begin{array}{c}\text { Stainless } \\
\text { sted }\end{array}$ & None & None & $\begin{array}{c}\text { Mincral } \\
\text { wool }\end{array}$ & $\$ 5,(0)(0,()()()$ \\
\hline Technigaz & $\begin{array}{l}\text { Carbon } \\
\text { stecl }\end{array}$ & $\begin{array}{c}\text { Incoloy } \\
8(0)\end{array}$ & $\begin{array}{c}\text { Refractory } \\
\text { bricks }\end{array}$ & $\begin{array}{c}\text { Mincral } \\
\text { wool }\end{array}$ & $\$ 10,37(0,0)(0)$ \\
\hline
\end{tabular}

Note 1. Installed cost, with insulation and foundation 


\section{CONCLUSIONS}

Based on this study, the following conclusions can be drawn regarding the steam generator designs:

- The only steam generator concept which has demonstrated nitrate salt service at $566 \mathrm{C}$ $(1,050 \mathrm{~F})$ is the $3 \mathrm{MWt} \mathrm{U}$-tube/IJ-shell design developed by Babcock and Wilcox for the Molten Salt Electric Experiment at Sandia National Laboratories in Albuquerque, New Mexico (Ref. 1-3). However, ABB Lummus has fabricated kettle boiler steam generators for the 80 MWe Luz Solar Electric Generating Stations (SEGS) which approach the size and main steam pressure required in this study. In addition, each design is judged to be technically feasible as reflected by the conceptual design, cost estimate, and offer of a warranty on workmanship and materials provided by each vendor

- The designs proposed by B\&W / SAIC and Foster Wheeler place the high pressure water or steam on the tube side of the heat exchangers. This minimizes the shell thicknesses, and in theory, should minimize the thermal inertia and the morning startup times. However, the morning startup time estimated by $A B B$ Lummus for the kettle evaporator is the same as that estimated by Foster Wheeler and B\&W / SAIC. In addition, the estimated startup times for 3 of the 4 steam generators are no longer, and may be shorter, than typical startup times for $100 \mathrm{MWe}$ and larger reheat turbines

- Discussions with heat exchanger specialists at Bechtel, and a review of specifications for heat exchangers purchased by Bechtel during the past 7 years, indicate that the vendors have selected fluid paths (shell or tube side) and temperature changes such that the heat exchangers operate under ypical commercial conditions. In particular, the maximum temperature difference between the inlet and outlet portions of the tubesheets in all of the designs does not exceed $110 \mathrm{C}(200 \mathrm{~F})$, and these conditions can be accommodated in commercial heat exchanger designs

- There is good agreement among the vendors regarding the costs of the heat exchangers; the divergence in the estimates occurs in the auxiliary equipment, engineering, and installation required for a complete system

- The steam generators evaluated for this study, including the U-f!be/U-shell design, are considerably less expensive than the design developed for Phase I of the Utility Studies. This may be attributed to the successful application of relatively lower cost kettle boilers in the Luz SEGS plants, and renewed vendor interest in commercial central receiver projects following the start of the Solar Two Project

- It appears that a steam generator for a $100 \mathrm{MWe}$ commercial project can be fabricated and installed for approximately $\$ 8$ million.

All of the steam generator designs evaluated in this study should be suitable for a commercial central receiver project, and the potential exists for procurement on a competitive basis from a number of qualified vendors. 
The following conclusions can be drawn regarding the hot salt storage tank designs:

- The only tank concept which has demonstrated nitrate salt service at $566 \mathrm{C}(1,0,50 \mathrm{~F})$ is the internally insulated design developed by Technigaz and Martin Marietta Corporation for the Subsystem Research Experiment at Sandia National Laboratories in Albuquerque, New Mexico (Ref. 1-3). However, CBI and PDM have fabricated tanks which approach the size and temperature required in this study, and each vendor is confident that a reliable design can be developed for a $100 \mathrm{MWe}$ commercial project

- The internally insulated tank isolates the shell-to-floor joint from the temperature of the nitrate salt inventory, and therefore, the tank design should be highly tolerant of rapid temperature changes. However, the importance of this feature is mitigated by the established transient performance of conventional tank designs. A transient thermal model developed by Sandia National Laboratories predicts that an empty hot salt tank will cool overnight at a rate of $1 \mathrm{C}(2 \mathrm{~F})$ per hour. The following morning, as salt from the receiver is introduced into the tank at an average temperature of $454 \mathrm{C}(8.50 \mathrm{~F})$, the tank will initially cool at a rate of $55 \mathrm{C}(100 \mathrm{~F})$ per hour. During the next 30 minutes, the temperature of the salt from the receiver will increase to the normal outlet value of $566 \mathrm{C}(1,050 \mathrm{~F})$. Once this temperature is reached, the tank will heat at a rate of approximately $22 \mathrm{C}(40 \mathrm{~F})$ per hour. Discussions with $\mathrm{CBI}$ and PDM indicate that large tanks can routinely tolerate temperature ramp rates up to $56 \mathrm{C}(100 \mathrm{~F})$ per hour without suffering excessive creep or fatigue damage Representative experience with large, externally insulated tanks which tolerate temperature transients at least as severe than those anticipated for a commercial solar project can also be found. For example, the thermal storage tanks for the SEGS I parabolic trough power plant are $21 \mathrm{~m}(70 \mathrm{ft})$ in diameter and routinely accommodate temperature change rates of 40 to $55 \mathrm{C}(75$ to $100 \mathrm{~F})$ per hour In addition, a nitrate salt tank $14 \mathrm{~m}(45 \mathrm{ft})$ in diameter fabricated by $\mathrm{CBI}$ for a proprietary chemical process plant in Texas normally operates at 260 $\mathrm{C}(500 \mathrm{~F})$, but is periodically filled very quickly with salt at $450 \mathrm{C}(842 \mathrm{~F})$

- During an extended shutdown, the hot tank will cool to $260(550 \mathrm{~F})$, at which time electric energy is used to maintain the temperature of the inventory. Following the restart of the receiver, the tank may be subject to a rapid change in the temperature of the inventory. Depending on the results of a detailed thermal analysis, the tank and inventory may need to be preheated prior to the restart of the receiver to avoid excessive thermal stresses. If so, the electric energy for preheating should be included in the comparisons of the tank designs. However, the steady state thermal loss from the internally insulated tank is greater than the loss from an externally insulated design. Therefore, some annual quantity of heat tracing for the externally insulated tank can be used before the annual performance of the two designs is equal. A first order thermal analysis shows that the steady state thermal loss from the internally insulated tank is approximately 2.5 times the average of the thermal losses from the CBI and PDM designs. Assuming a Rankine cycle efficiency of 40 percent, the electric heat tracing on the externally insulated tanks could, in theory, be operated continuously and still offer the same annual thermal efficiency as the internally insulated design. Clearly, tank designs requiring such an operating strategy would not be proposed. However, it is apparent that the periodic use of trace heating on externally insulated tanks, should it be needed to limit transient thermal stresses, can be justified 
- The Technigaz liner has demonstrated reliable service in numerous liquified natural gas tank installations. However, if a leak should develop in the liner of a nitrate salt tank, it is estimated that the repair procedure would be more lengthy than for an externally insulated tank. The time required to cool the inside of the tank, and in particular the thermal mass of the 512,000 refractory bricks, before repair personnel could enter would be considerably longer. In addition, the extent to which the refractory was contaminated with salt would need to be determined, and those bricks which had absorbed salt would need to be replaced. The estimated time to repair a leak in an externally insulated tank is 5 to 9 days, while the time for an internally insulated tank is estimated to be 15 to 30 days. Thus, the frequency of leaks in an internally insulated tank can be only one-half to one-third of that in an externally insulated design without suffering a disadvantage in annual availability

- There is good agreement on the cost estimates from the two vendors offering externally insulated designs and who are potential suppliers to the Solar Two and early commercial projects

- It appears that an externally insulated hot salt tank for a $100 \mathrm{MWe}$ commercial project can be fabricated and installed for approximately $\$ 5$ million. An internally insulated design is projected to be approximately twice as expensive.

Both the internally and externally insulated designs are judged to be acceptable for commercial service, and the potential exists for procurement on a competitive basis from a number of qualified vendors.

\section{FUTURE ACTIVITIES}

This study leaves unresolved the selection of the preferred hot salt tank and steam generator designs for the first commercial project. In particular, a definitive selection cannot be made without firm cost estimates, and it is believed that these estimates can only be obtained as part of the procurement process prior to plant construction

A possible approach to the selection of an optimum storage tank during project procurement is outlined below. A final set of procedures will be developed as part of the Solar Two Project, and these may also form the basis for procurement activities in the first commercial project. The first steps would involve calculations by the plant engineer of the following:

- Temperature and flow rate of the salt from the receiver over the course of a year

- Minimum salt temperature to the hot tank during morning startup and following cloud transients

- Inventory required to operate the auxiliary steam generator during the daily turbine startup.

From these calculations, the temperature to, and the flow rate to and from, the hot tank over the course of a year can be determined. This information would be included in the bid package to the tank vendors. 
The vendors would conduct analyses of transient thermal stresses and fatigue damage, and then develop the tank designs, operating requirements, thermal losses, leak repair times, and bid prices. The vendors will be free to select their optimum combination of features. For example, an inexpensive shell-to-floor joint with a thick salt heel may be a lower cost solution to transient stresses than a more sophisticated curved joint with a thin heel. Similarly, the vendor would specify any constraints on tank operation. For example, if the inventory temperature must be maintained at $480 \mathrm{C}(900 \mathrm{~F})$ during an extended shutdown to prevent excessive thermal stresses following the plant startup, this information would be included in the bids to the project.

The engineer would evaluate all of the bids received, and develop total annual capital and operating costs (including possible repairs) for each vendor. From this, definitive comparisons with competing designs could be made and the optimum design selected.

A similar set of procedures would be required to assess the competing steam generator designs. In particular, overnight thermal conditioning requirements would be a principal consideration in the analysis. However, more detailed operating procedures, including limits placed on morning startup rates by the turbine, would need to be developed before formal requests for proposals could be prepared. 


\section{Section 2 \\ Background and Introduction}

In 1986, two utilities, Arizona Public Service Company (APS) and Pacific Gas and Electric Company (PG\&E), entered into a cooperative agreement with the Department of Energy to define the first generation of commercial central receiver power plants. The study, entilled "Solar Central Receiver Technology Advancement for Electric Utility Applications" (and called the "Utility Studies" for convenience), had two phases. The goal of Phase I was to develop a consensus on the preferred near term commercial plant design, and the goal of Phase II was to es' ablish a development plan to commercialize the technology. The study selected a $100 \mathrm{MWe}$ plant with a cylindrical nitrate salt receiver and a surround heliostat field as the preferred commercial design, and recommended the conversion of the $10 \mathrm{MWe}$ Solar One pilot plant to nitrate salt technology as the lowest cost approach to commercialize the technology.

\section{UTILITY STUDIES PHASE I STEAM GENERATOR AND THERMAL STORAGE TANK DESIGNS}

The principal objective of Phase I during the Utility Studies was to select the preferred receiver coolant. To this end, the design of various equipment items was fixed early in the study so as not to divert attention from the receiver optimization studies These items included the following:

Steam Generator The design and cost of the steam generator were based on a study for a $100 \mathrm{MWe}$ plant prepared by Babcock and Wilcox for Sandia National Laboratories in 1982 (Ref. 2-1), and a $3 \mathrm{MWt}$ unit fabricated by Babcock and Wilcox for Sandia National Laboratories and tested at the Molten Salt Electric Experiment in 1985 (Ref. 1-3). The design used U-tube/U-shell heat exchangers and a forced recirculation evaporator. The high pressure fluid (water/steam) was placed on the ube side in each heat exchanger, and the low pressure fluid (nitrate salt) on the shell side. The installed cost, in third quarter 1987 dollars, was estimated to be $\$ 11.1$ million.

The U-shell concept allowed the inlet channel tubesheet to be separated from the outlet tubesheet, and thereby avoided the exposure of a single tubesheet to the large temperature gradients inherent in the superheater and reheater. Similar reasoning in a second steam generator study for Sandia by Foster Wheeler Solar Development Corporation in 1982 led to the selection of straight tube/straight shell heat exchangers (Ref. 2-2). Differential thermal expansion between the tubes and shell was accommodated by a bellows surrounding the inlet water/steam piping

Thermal Storage Tanks The design and cost estimate were developed by Chicago Bridge and Iron Technical Services Company (CBI) and assumed a "conventional" approach using vertical, atmospheric pressure tanks with external calcium silicate insulation. The cold and hot tanks were fabricated from carbon steel and stainless steel, respectively, and cooling air passages were located in the foundation to prevent native soil temperatures from exceeding $100 \mathrm{C}(212 \mathrm{~F})$. The installed costs of the cold and hot tank, in third quarter 1987 dollars, were estimated to be $\$ 1.0$ million and $\$ 3.0$ million, respectively. A brief parallel study by Pitt-Des Moines, Inc. (PDM) resulted in tank designs similar to the CBI concept. 
At the time of the study, CBI and PDM had designed and fabricated tanks to requirements which were similar, but not identical, to those for nitrate salt at $566 \mathrm{C}(1,050 \mathrm{~F})$. The only design which has been proven for this service is one developed by $\mathrm{S}$. N. Technigaz (a French company) and Martin Marietta Corporation. A 7 MWht thermal storage system was installed at the Central Receiver Test Facility at Sandia National Laboratories in Albuquerque, New Mexico (Ref. 2-3). The cold salt tank used a carbon steel shell with external insulation, while the hot tank a carbon steel shell with internal and external insulation. To limit the shell temperature on the hot tank to acceptable values, a layer of refractory brick was installed inside the shell. A thin, corrugated Incoloy sheet lined the inside of the bricks to protect the refractory from the corrosive effects of the nitrate salt. The design was more complex than a stainless steel tank, but it offered the advantages of a low cost pressure boundary and the ability to accept rapid temperature changes. Cost analyses by Sandia National Laboratories using information developed by Martin Marietta Corporation showed the tank to be competitive with the designs with external insulation (Ref. 2-4).

\section{UTILITY STUDIES PHASE II STEAM GENERATOR AND THERMAL STORAGE TANK DESIGNS}

During Phase II, a conceptual design and cost estimate were developed for the conversion of Solar One to nitrate salt technology. Potential heat exchanger and tank vendors were contacted for conceptual designs and budgetary estimates of a $35 \mathrm{MW}$ nitrate salt steam generator and an 80 MWht thermal storige system, respectively.

Two of the three heat exchanger vendors recommended a kettle boiler concept, in which saturated steam is generated in a pool on the shell side of the evaporator. This approach was selected based in part on the successful operation of similar equipment at the Luz Solar Electric Generating Station parabolic trough solar power plants, and on the potential for a lower capital cost. The third vendor, Babcock and Wilcox, recommended the U-tube/U-shell design. Both of the tank vendors recommended externally insulated tanks, with the cold salt tank fabricated from carbon steel and the hot tank from stainless steel. However, an alternate hot salt tank design using a carbon steel shell and internal insulation was not evaluated Thus, there were several differences between the equipment designs for the first commercial plant and the $10 \mathrm{MWe}$ plant that was to precede it, and the conceptual nature of the Phase II study could not resolve these issues

\section{INVESTIGATION OF THERMAL STORAGE AND STEAM GENERATOR ISSUES}

Late in 1991, Southern California Edison Company organized a group of utilities and government organizations, and submitted a proposal to DOE to convert the Solar One plant to nitrate salt technology (Solar Two). The purpose of the project was to reduce the perceived risk in building the first commercial $100 \mathrm{MWe}$ plant. To this end, Solar Two needed to duplicate the technical features of the first commercial plant as closely as possible

The question arose. What should be the steam generator and thermal storage tank designs in the first commercial plant? This study sought a partial answer by reviewing potential equipment designs and identifying those which would be suitable. The approach involved the following steps

- Subcontracts were placed with four heat exchanger vendors and three tank vendors to examine the full range of options 
- The vendors developed conceptual designs and cost estimates for the equipment required in the first $100 \mathrm{MWe}$ commercial plant

- Bechtel reviewed the vendor information, assessed the technical feasibility of each design, and determined whether the equipment would be suitabie for the commercial plant.

It should be noted that the purpose of the study was limited to an assessment of the feasibility of each design, and not a selection of the best equipment concept.

Section 3 of this report reviews the steam generator designs, Section 4 reviews the thermal storage tank designs, and Section 5 lists the references. Appendices A and B are statements of work for the steam generator and thermal storage tank vendors, respectively. 


\section{Section 3 \\ Steam Generator Designs and Cost Estimates}

Four conceptual steam generator designs and cost estimates were developed during this study. Two of the designs, one developed by ABB Lummus Heat Transfer (ABB Lummus) and a second by Struthers Wells Corporation (Struthers Wells), employed U-tube/straight shell heat exchangers with a kettle steam generator. The third design, prepared by Foster Wheeler Development Corporation (Foster Wheeler), employed straight tube/straight shell heat exchangers with bellows to accommodate differential thermal expansion between the shell and tubes. The fourth design, presented by Science Applications International Corporation (SAIC) teamed with the Babcock and Wilcox Company (B\&W), used U-tube/U-shell heat exchangers and a separate steam drum.

The discussion which follows reviews the steam generator specification, design features, warranty provisions, and cost estimate for each of the concepts

\section{SPECIFICATION}

The principal specification used in the design of all of the steam generators is presented in Table 3-1. The steam generator is intended for a nominal $100 \mathrm{MWe}$ commercial plant using a reheat turbine cycle. It is sized to produce $92.77 \mathrm{~kg} / \mathrm{sec}(736,300 \mathrm{lb} / \mathrm{hr})$ of main steam at a pressure of $13.03 \mathrm{MPa}$ $(1,890 \mathrm{psia})$ and a temperature of $540 \mathrm{C}(1,004 \mathrm{~F})$ from a feedwater flow of $93.71 \mathrm{~kg} / \mathrm{sec}(743,700$ $\mathrm{lb} / \mathrm{hr})$ at a temperature of $236 \mathrm{C}(456 \mathrm{~F})$. The steam generator must also reheat $79.92 \mathrm{~kg} / \mathrm{sec}$ $(634,300 \mathrm{lb} / \mathrm{hr})$ of intermediate pressure steam from the turbine, raising its temperature from $347 \mathrm{C}$ $(656 \mathrm{~F})$ to $538 \mathrm{C}(1,000 \mathrm{~F})$.

A value of $\$ 2,300 / \mathrm{m}(\$ 700 / \mathrm{ft})$ of pressure drop on the salt side of the heat exchangers was assigned to assist the vendors in selecting the optimum heat exchange area and tube configuration.

\section{DESIGN FEATURES}

The principal features of the four heat exchanger designs are summarized in Table 3-2. Shown are the tube and shell configurations, materials, duties, fluid temperatures, log mean temperature differences, overall heat transfer coefficients, and net heat exchange areas.

Although each vendor worked to the same specification, there are many differences in the heat exchanger details. These can be attributed to the following:

- Preferred approach to accommodating thermal expansion. For example, Foster Wheeler uses straight tube/straight shell heat exchangers with floating tubesheets, while ABB Lummus, B\&W / SAIC, and Struthers Wells each use U-tubes with fixed tubesheets.

- Different approaches to circulation in the evaporator. Foster Wheeler and B\&W / SAIC use natural and forced recirculation, respectively, while ABB Lummus and Struthers Wells use kettle boilers 
Table 3-1

STEAM GENERATOR PERFORMANCE SPECIFICATION

Nominal Ratings

Final Feedwater

Main Steam

Cold Reheat Steam

Hot Reheat Steam

Nitrate Salt
$110 \mathrm{MWe}$ gross plant output $260 \mathrm{MWt}$ steam generator duty

$236 \mathrm{C}(456 \mathrm{~F})$

(As required) $\mathrm{MPa}$ (psia)

$93.71 \mathrm{~kg} / \mathrm{sec}(743,700 \mathrm{lb} / \mathrm{hr}) ; 1 \%$ blowdown assumed

$540 \mathrm{C}(1,004 \mathrm{~F})$

$13.03 \mathrm{MPa}(1,890$ psia $)$

$92.77 \mathrm{~kg} / \mathrm{sec}(736,300 \mathrm{lb} / \mathrm{hr})$

$347 \mathrm{C}(656 \mathrm{~F})$

$3.08 \mathrm{MPa}(446 \mathrm{psia})$

$79.92 \mathrm{~kg} / \mathrm{sec}(634,300 \mathrm{lb} / \mathrm{hr})$

$538 \mathrm{C}(1,000 \mathrm{~F})$

$2.77 \mathrm{MPa}(402 \mathrm{psia})$

$79.92 \mathrm{~kg} / \mathrm{sec}(634,300 \mathrm{lb} / \mathrm{hr})$

$566 \mathrm{C}(1,050 \mathrm{~F})$ inlet temperature

(As required) $\mathrm{MPa}$ (psia) inlet pressure

$454 \mathrm{C}(850 \mathrm{~F})$ maximum evaporator tube temperature consistent

with acceptable corrosion rates for chrome-moly tubes

$288 \mathrm{C}(550 \mathrm{~F})$ outlet temperature

$138 \mathrm{kPa}(20 \mathrm{psia})$ outlet pressure

Specific heat

$0.345+\left(2.28 \times 10^{-5}\right)($ Temp, F $)$, Btu/lb $b_{m}-F$

Density

$131.2-\left(2.221 \times 10^{-2}\right)($ Temp, $\mathrm{F}), \mathrm{lb}_{\mathrm{m}} / \mathrm{ft}^{3}$

Thermal conductivity

$0.25308+\left(6.26984 \times 10^{-5}\right)($ Temp, F $)$, Btu/hr-ft-F

Viscosity

$60.2844-(0.17236)($ Temp, F $)+\left(1.76176 \times 10^{-4}\right)(\text { Temp, F })^{2}$

$-\left(6.11408 \times 10^{-8}\right)(\mathrm{Temp}, \mathrm{F})^{3}, \mathrm{Ib}_{\mathrm{m}} / \mathrm{ft}-\mathrm{hr}$ 
Table 3-2

COMPARISON OF STEAM GENERATOR TECHNICAL CHARACTERISTICS - PREHEATER

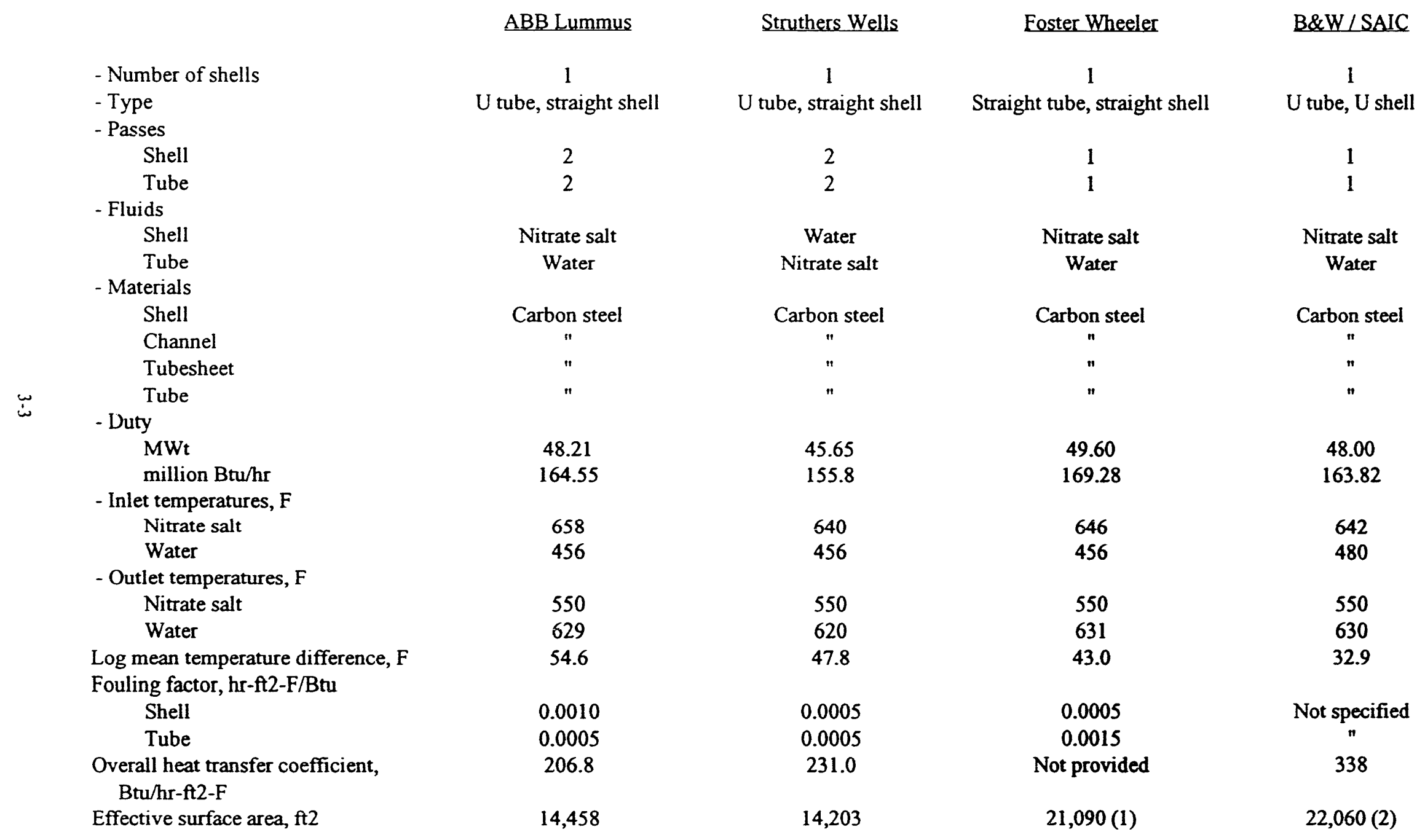

1) Represents an 18.5 percent margin on heat transfer area, including a 3 percent allowance for tube plugging

2) Includes 25 percent margin on heat transfer area 
Table 3-2 (Continued)

COMPARISON OF STEAM GENERATOR TECHNICAL CHARACTERIS TTCS - EVAPORATOR

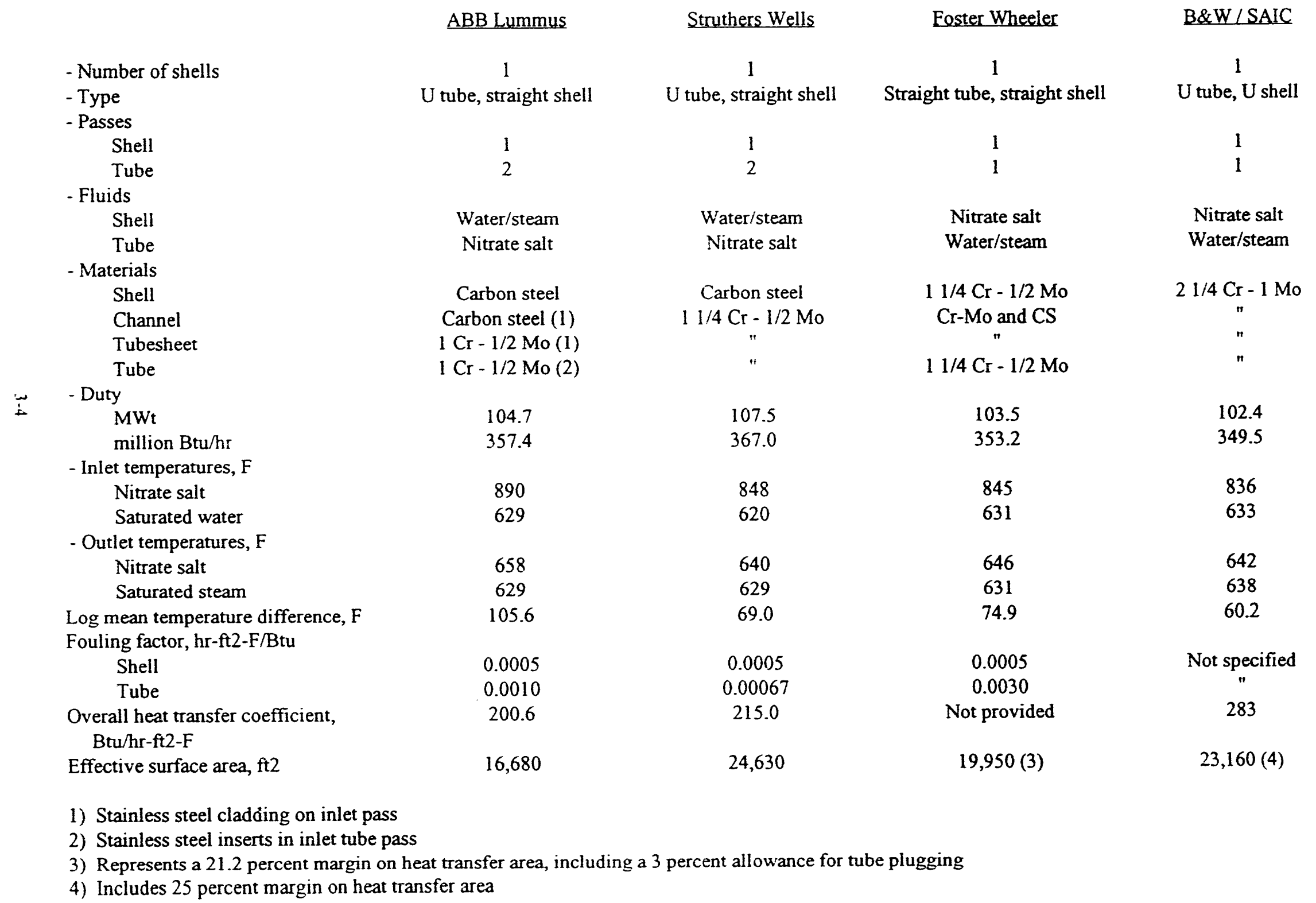


Table 3-2 (Continued)

COMPARISON OF STEAM GENERATOR TECHNICAL CHARACTERISTICS - SUPERHEATER

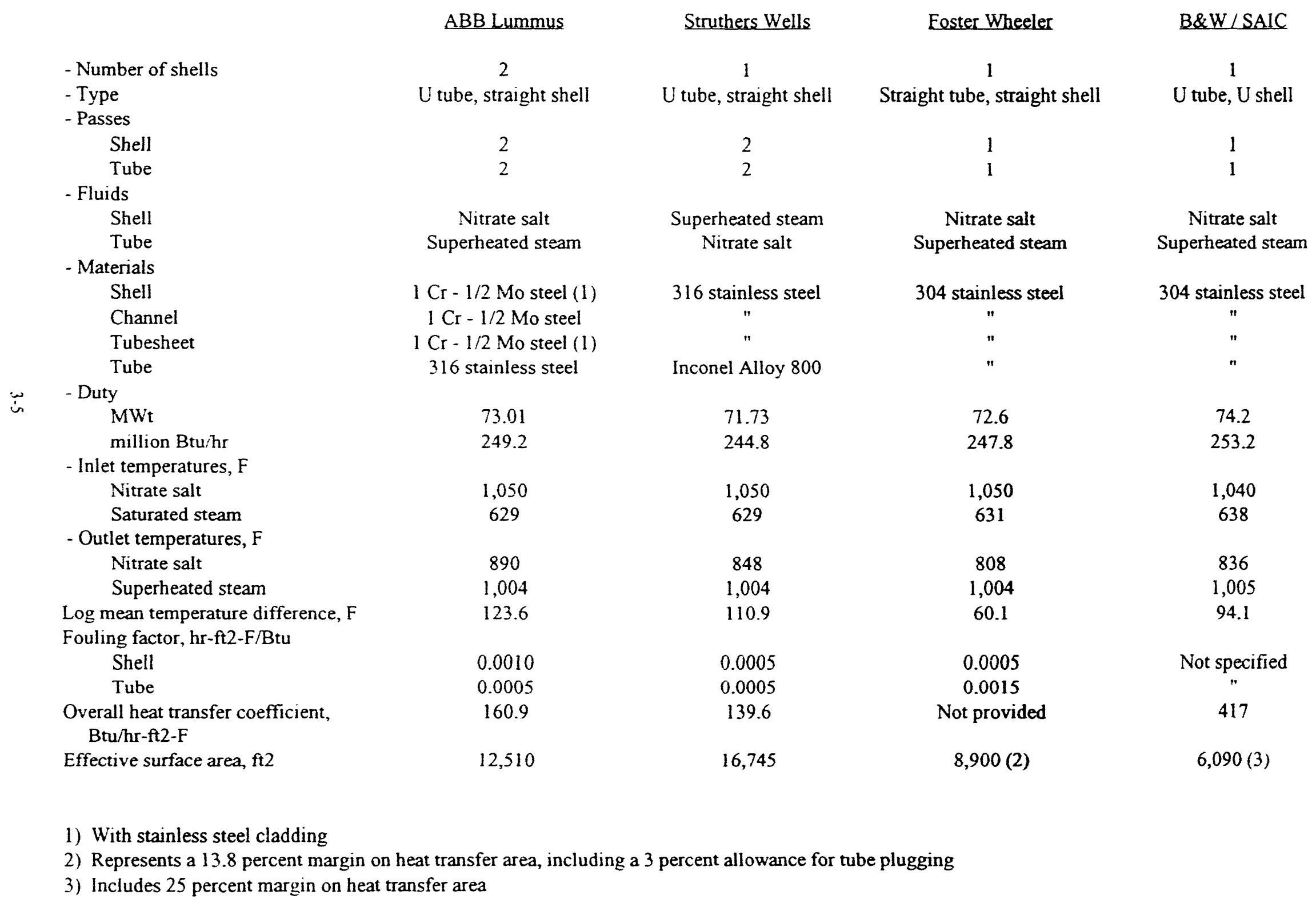


Table 3-2 (Continued)

COMPARISON OF STEAM GENERATOR TECHNICAL CHARACTERISTICS - REHEATER

\begin{tabular}{|c|c|c|c|c|}
\hline & ABB Lummus & Struthers Wells & Foster Wheeler & B\&W / SAIC \\
\hline - Number of shells & 1 & 1 & 1 & 1 \\
\hline - Type & U tube, straight shell & U tube, straight shell & Straight tube, straight shell & U tube, U shell \\
\hline \multicolumn{5}{|l|}{ - Passes } \\
\hline Shell & 2 & 2 & 1 & 1 \\
\hline Tube & 2 & 2 & 1 & 1 \\
\hline \multicolumn{5}{|l|}{ - Fluids } \\
\hline Shell & Superheated steam & Superheated steam & Nitrate salt & Nitrate salt \\
\hline Tube & Nitrate salt & Nitrate salt & Superheated steam & Superheated steam \\
\hline \multicolumn{5}{|l|}{ - Materials } \\
\hline Shell & $1 \mathrm{Cr}-1 / 2$ Mo steel & 316 stainless steel & 304 stainless steel & 304 stainless steel \\
\hline Channel & $1 \mathrm{Cr}-1 / 2 \mathrm{Mo}$ steel (1) & $"$ & $"$ & $n$ \\
\hline Tubesheet & $"$ & $"$ & $"$ & $"$ \\
\hline Tube & 316 stainless steel & Inconel Alloy 800 & $"$ & $"$ \\
\hline \multicolumn{5}{|l|}{ - Duty } \\
\hline $\mathrm{MWt}$ & 34.72 & 35.86 & 34.5 & 34.7 \\
\hline million Btu/hr & 118.5 & 122.4 & 117.7 & 118.4 \\
\hline \multicolumn{5}{|l|}{ - Inlet temperatures, F } \\
\hline Nitrate salt & 1,050 & 1,050 & 1,050 & 1,040 \\
\hline Saturated Steam & 656 & 656 & 656 & 656 \\
\hline \multicolumn{5}{|l|}{ - Outlet temperatures, F } \\
\hline Nitrate salt & 850 & 848 & 898 & 836 \\
\hline Superheated Steam & 1,000 & 1,000 & 1,000 & 1,000 \\
\hline Log mean temperature difference, $F$ & 101.5 & 105.6 & $12 i .8$ & 93.1 \\
\hline \multicolumn{5}{|l|}{ Fouling factor, $\mathrm{hr}-\mathrm{ft} 2-\mathrm{F} / \mathrm{Btu}$} \\
\hline Shell & 0.0005 & 0.0005 & 0.0005 & Not specified \\
\hline Tube & 0.0010 & 0.0005 & 0.0015 & $"$ \\
\hline $\begin{array}{l}\text { Overall heat transfer coefficient, } \\
\text { Btu/hr-ft2-F }\end{array}$ & 107.7 & 72.54 & Not provided & 188 \\
\hline Effective surface area, $\mathrm{ft} 2$ & 10,830 & 16,880 & $6,200(2)$ & $8,480(3)$ \\
\hline \multicolumn{5}{|c|}{ 1) Stainless steel cladding on inlet pass } \\
\hline \multicolumn{5}{|c|}{ 2) Represents a 13.1 percent margin on heat transfer area, including a 3 percent allowance for tube plugging } \\
\hline \multicolumn{5}{|c|}{ 3) Includes 25 percent margin on heat transfer area } \\
\hline
\end{tabular}


- Different unit costs for materials and labor, which lead to differences in the optimum heat exchange area

- Different assumptions regarding fouling factors and design margins, which influence the required heat exchange area. For example, B\&W / SAIC adds a margin of 25 percent to the calculated areas, while Foster Wheeler uses a margin of 13 to 21 percent including 3 percent for tube plugging

A discussion of the similarities and differences among the designs is presented below.

\begin{abstract}
A BB Lummus Kettle Boiler Steam Genemator
The ABB Lummus design includes a U-tube kettle boiler and U-tube/straight shell heat exchangers for the preheater, superheater, and reheater. A flow schematic is presented in Figure 3-1. The approach uses conventional heat exchanger designs, and draws on the experience gained in fabricating the steam generators for the Luz Solar Electric Generating Stations.
\end{abstract}

It should be noted that while much of the Luz experience is applicable, the two steam generators are designed for different conditions. The Luz equipment used synthetic oil for the heat transport fluid and generated main steam at $10,0 \mathrm{MPa}(1,450 \mathrm{psia})$ and $371 \mathrm{C}(700 \mathrm{~F})$; main steam conditions for the nitrate salt steam generator are $13.03 \mathrm{MPa}(1,890 \mathrm{psia})$ and $540 \mathrm{C}(1,005 \mathrm{~F})$. In addition, the temperature range of the oil was only $100 \mathrm{C}(180 \mathrm{~F})$ while the range for the nitrate salt is $278 \mathrm{C}(500$ $\mathrm{F})$. This larger range placed constraints on the selection of tube and shell fluids in the nitrate salt steam generator, and resulted in the use of two superheater shells in series and placing the steam flow on the shell side of the reheater.

Superheater and Reheater Arrangements Selecting a design with two superheaters in series offers two benefits. First, the steam temperature increases $208 \mathrm{C}(375 \mathrm{~F})$ as it progresses from the evaporator outlet to the superheater outlet. The use of two superheaters allows this increase to occur in two steps, and limits the temperature difference between the inlet and outlet portions of the tubesheet to $104 \mathrm{C}(188 \mathrm{~F})$. This is a moderate gradient and is routinely used in commercial heat exchangers. The limited gradient allows the high pressure steam to be placed on the tube side of the heat exchanger, which reduces the thickness and cost of the shell. Second, salt attemperation for main steam temperature control occurs at a lower temperature than if the cold salt were mixed at the inlet to the superheaters. Although this effect is minor, the thermodynamic efficiency is higher than if attemperation was done at the inlet to the superheater

The large temperature change of the reheat steam ( $191 \mathrm{C}(344 \mathrm{~F})$ ) places the same constraints on the reheater design. However, ABB Lummus elected to place the high pressure steam on the shell side and limit the number of reheater shells to one. The reheater duty was approximately one-half the superheater duty, and the lowest cost approa in may have been to fabricate one heat exchanger with a high pressure shell rather than two small heat exchangers with low pressure shells. This is the same approach as adopted in the Struthers Wells reheater design. 


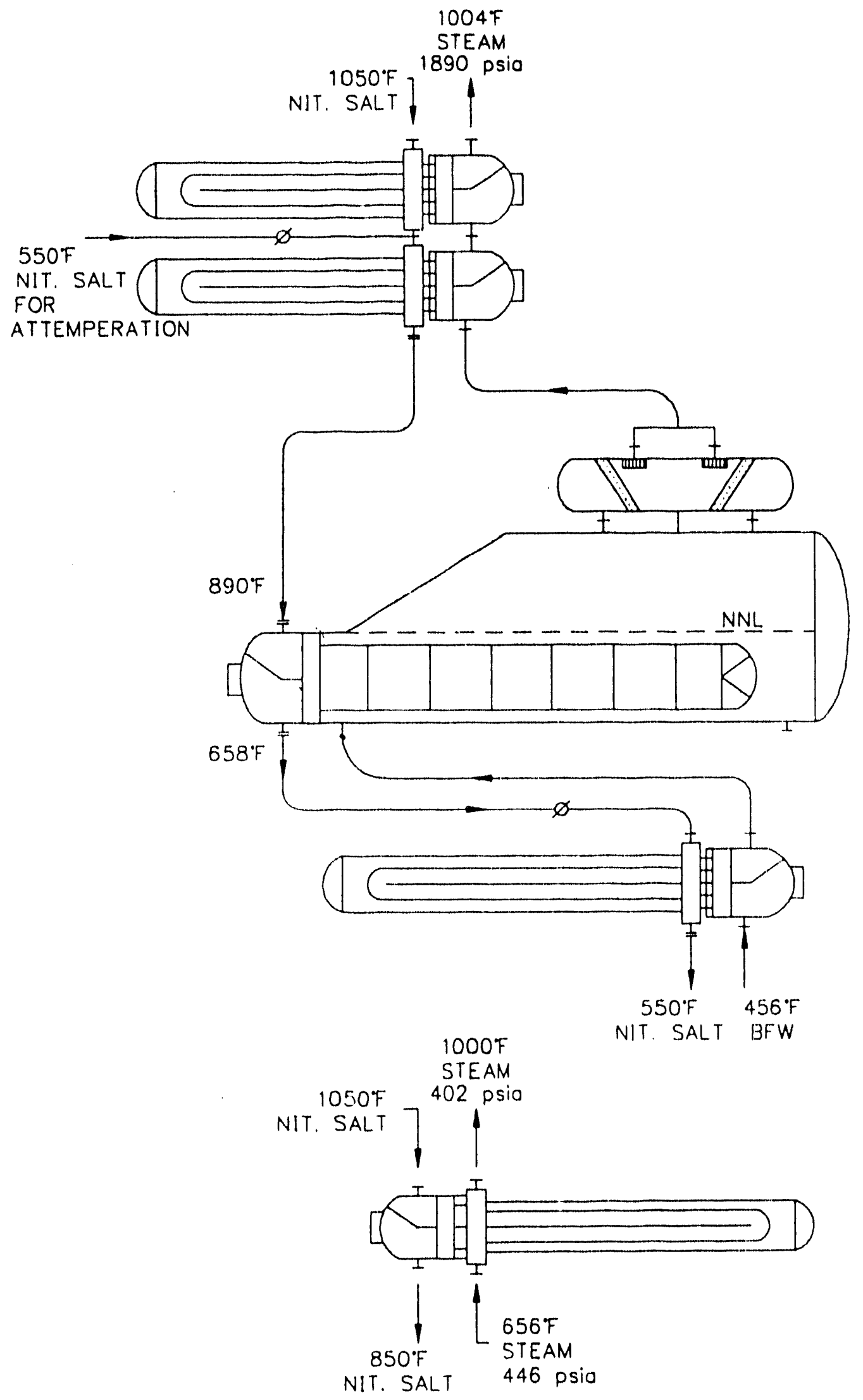

SUPERHEATER SSH

SEPARATOR

STEAM GENERATOR SSG

PREHEATER SPH

REHEATER SRH

Figure 3-1 ABB Lummus Steam Generator Flow Schematic 
Evaporator Inlet Flow One unusual feature of the ABB Lummus design centers on the salt flow to the evaporator. Note in the flow schematic that the salt flows through the two superheaters and into the evaporator, but that the flow from the reheater returns to the storage system at a temperature of $454 \mathrm{C}(850 \mathrm{~F})$. Apparently, the engineers at ABB Lummus were not aware of the "typical" steam generator configuration, in which the flows through the superheater and reheater are combined and directed to the evaporator. However, the "typical" arrangement was not made clear in the specification prepared by Bechtel, and $\mathrm{ABB}$ Lummus should not be criticized for selecting a design that is not directly comparable to those from the other vendors.

The misunderstanding is not without benefit. By separating the superheater and reheater outlet flows, the salt inlet temperature to the evaporator is raised $22 \mathrm{C}(40 \mathrm{~F})$ above the allowable value of $454 \mathrm{C}(850 \mathrm{~F})$. To prevent excessive corrosion of the $\mathrm{I} \mathrm{Cr}-1 / 2 \mathrm{Mo}$ channel and tube materials, ABB Lummus proposed that the inlet channel and the high temperature portion of the tubes be clad with stainless steel. Sandia National Laboratories is currently conducting a survey of ferritic material corrosion rates, and is considering disassembly and examination of the $2 \frac{1}{4} \mathrm{Cr}-1$ Mo tube and shell materials used in the evaporator of the Molten Salt Electric Experiment steam generator. If it is determined that ferritic materials with chromium contents of 1 to $2 \frac{1}{4}$ percent are not compatible with nitrate salt at temperatures up to $4.54 \mathrm{C}(8.50 \mathrm{~F})$, stainless steel cladding of the high temperature portions of the evaporator could be considered as an option to ferritic materials with a high chromium content, such as $9 \mathrm{Cr}-1 \mathrm{Mo}$

\section{Stuuthers Wells Kettle Boiler Stenm Generitor}

The Struthers Wells design is very similar to the ABB L.ummus concept It includes a U-tube kettle boiler and U-tube/straight shell heat exchangers for the preheater, superheater, and reheater $A$ flow schematic is presented in Figure 3.2

The Struthers Wells design differs from the ABB Lummus concept in two areas First, the water/steam separators in the evaporator are placed inside the kettle boiler rather than outside. This eliminates the need for a separate vessel, but increases the kettle diameter and wall thickness by approximately 12 percent second, only one superheater shell is used. This reduces the number of heat exchangers, but requires the high pressure steam to be placed on the shell side of the heat exchangers As discussed above, a temperature change of $110(200 \mathrm{~F})$ between the inlet and outlet channels is common in commercial heat exchangers However, a change of $200 \mathrm{C}(360 \mathrm{~F})$ would not be typical Since the nitrate salt and steam temperature changes in the heat exchanger are 112 ( $(202 \mathrm{~F})$ and $208 \mathrm{C}(375 \mathrm{~F})$, respectively, the steam was placed on the shell side

\section{Foster Wheeler Straight Tube Steam Genemator}

The Foster Wheeler design includes straight mbe/straight shell heat exchangers for the preheater, evaporator, superheater, and reheater. The evaporator design is unique in that it incorporates the steam drum in the steam outlet channel. Bellows surrounding the inlet water or steam piping accommodate differential thermal expansion between the tubes and shell. A flow schematic is presented in Figure 3-3 


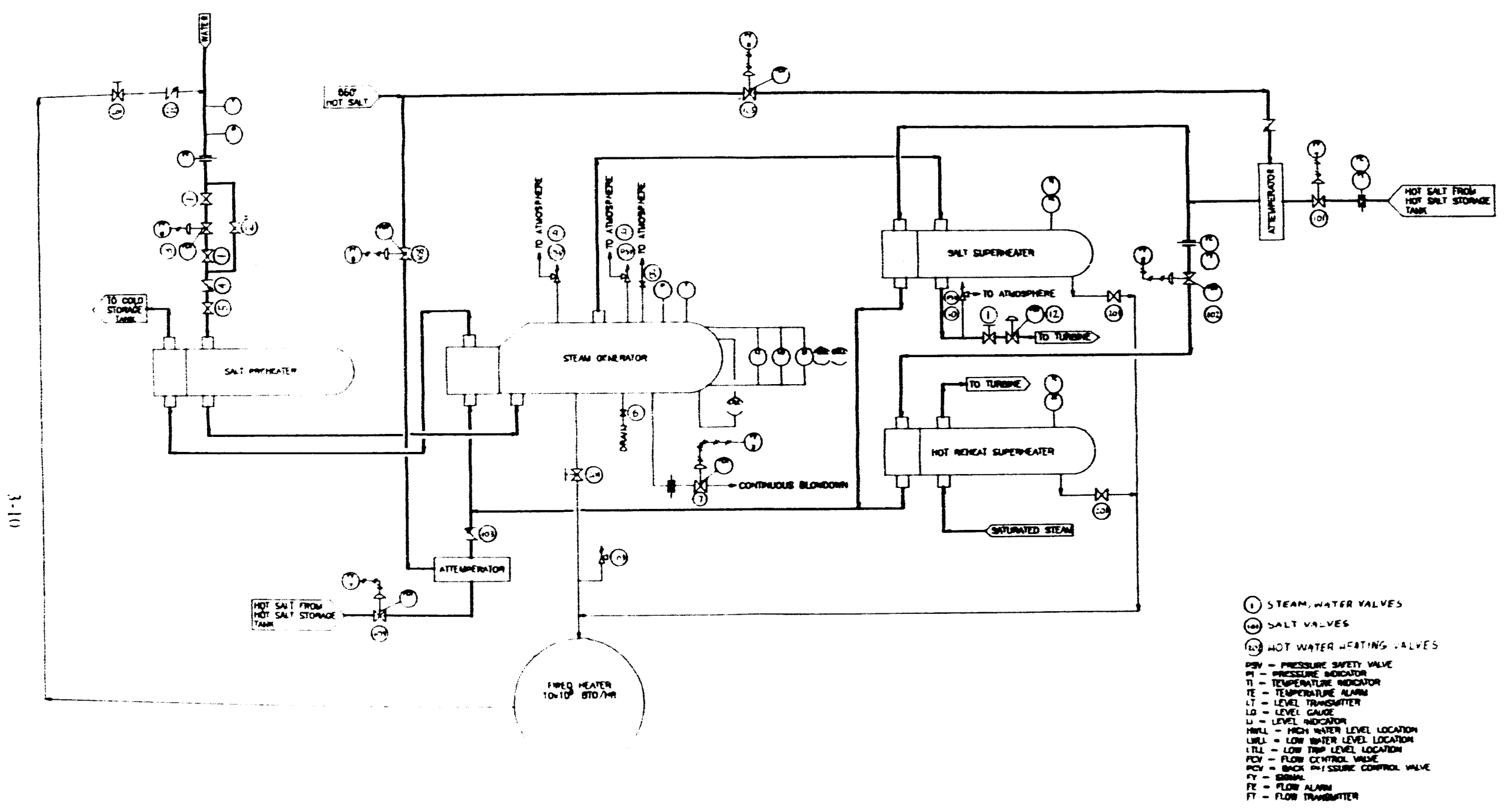

Figure 3-2 Struthers Wells Steam Generator Flow Schematic 


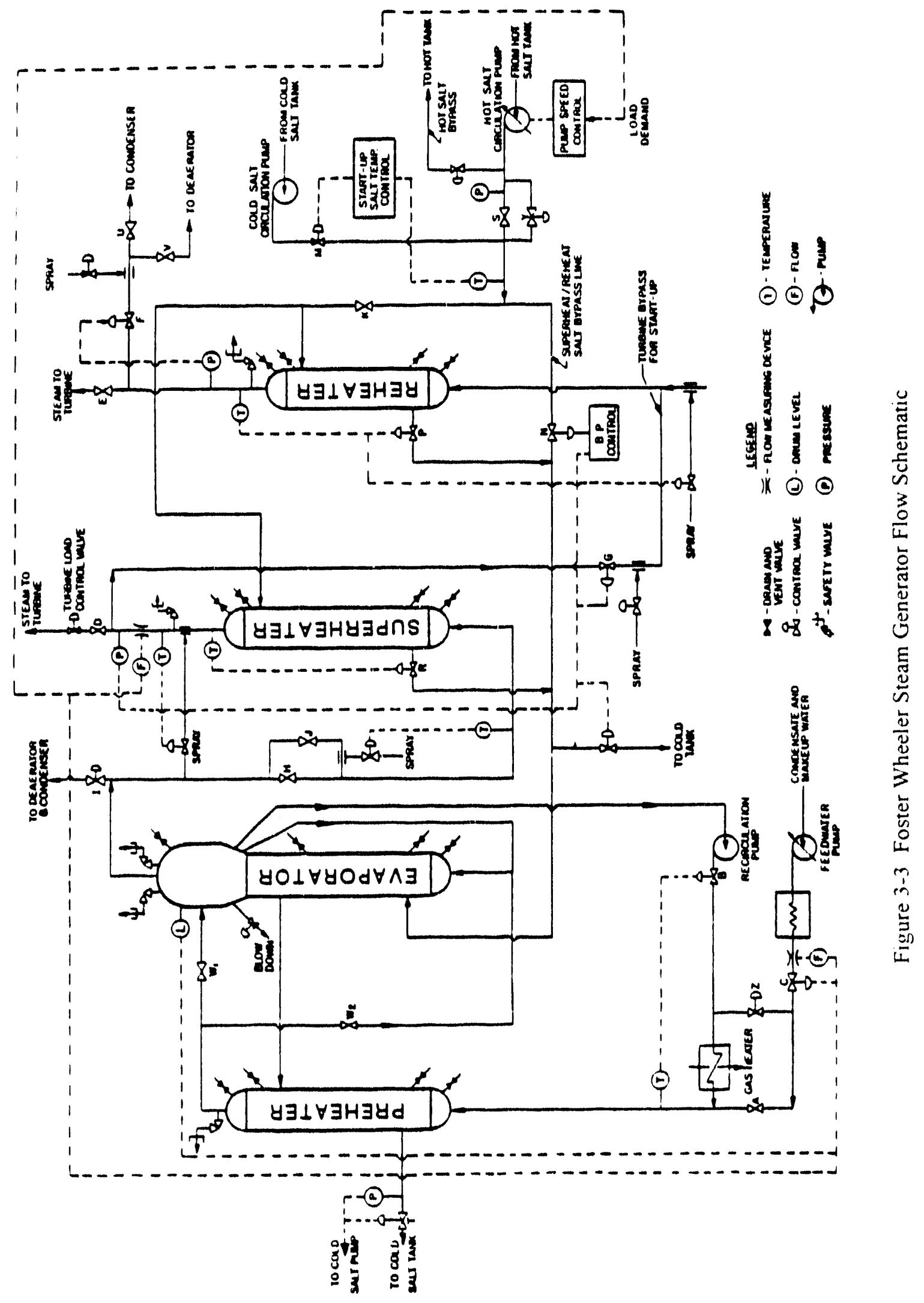


The design is a moderate revision to an essentially identical $100 \mathrm{MWe}$ steam generator study prepared for Sandia National Laboratories in 1982 (Ref. 2-1). The 1982 report described in detail the selection rationale for the straight tube/straight shell heat exchangers, thermal analysis, hydraulic performance, mechanical design, boiling stability analysis, and operating procedures. The principal features included the following:

- To permit the use of bellows, all nitrate salt flows are on the shell side. The bellows are located outside the inlet water or steam piping, rather than in the shell, to limit the bellow sizes

- The large differential thermal expansion due to steam temperature changes in the superheater and reheater are readily accommodated by the separate inlet and outlet tubesheets

- A natural circulation evaporator was selected over forced recirculation, once-through, and Sulzer types. To promote the required circulation, the evaporator is arranged vertically, and to reduce pressure losses and costs, the steam drum is located in the outlet channel of the evaporator. The preheater, superheater, and reheater are also arranged vertically to simplify the support structure

- The preheater, superhealer, and reheater use a counter flow arrangement. The evaporator uses parallel flow to improve natural circulation

The current design was adapted from the 1982 study by adjusting heat exchanger tube lengths to account for slightly lower thermal ratings. The adjustments ranged from -3 percent for the preheater to -1.5 percent for the reheater.

\section{B\&WV / SAIC U-Tube/U-Shell Steam Genentor}

The B\&W / SAIC design includes U-tube/U-shell heat exchangers for the preheater, evaporator, superheater and reheater, and an elevated steam drum between the evaporator and superheater. A flow schematic is presented in Figure 3-4 (Salt Side) and Figure 3-5 (Water/Steam Side). The design, which evolved from a parallel study to that conducted by Foster Wheeler in 1982 for Sandia National Laboratories (Ref 2-2), has several features which are different from the other vendors. These include the following

- Separate inlet and outlet tubesheets reduce the constraints on temperature change in one heat exchanger; thus, the high pressure water/steam flows can be placed on the tube side and shell thicknesses held to a minimum

- The U-shaped tubes accommodate differential thermal expansion between the tubes and shell without the need for the floating tubesheets or bellows normally required with separate inlet and outlet tubesheets

- The heat exchangers, including the evaporator, are arranged horizontally; thus, boiling occurs in horizontal tubes 


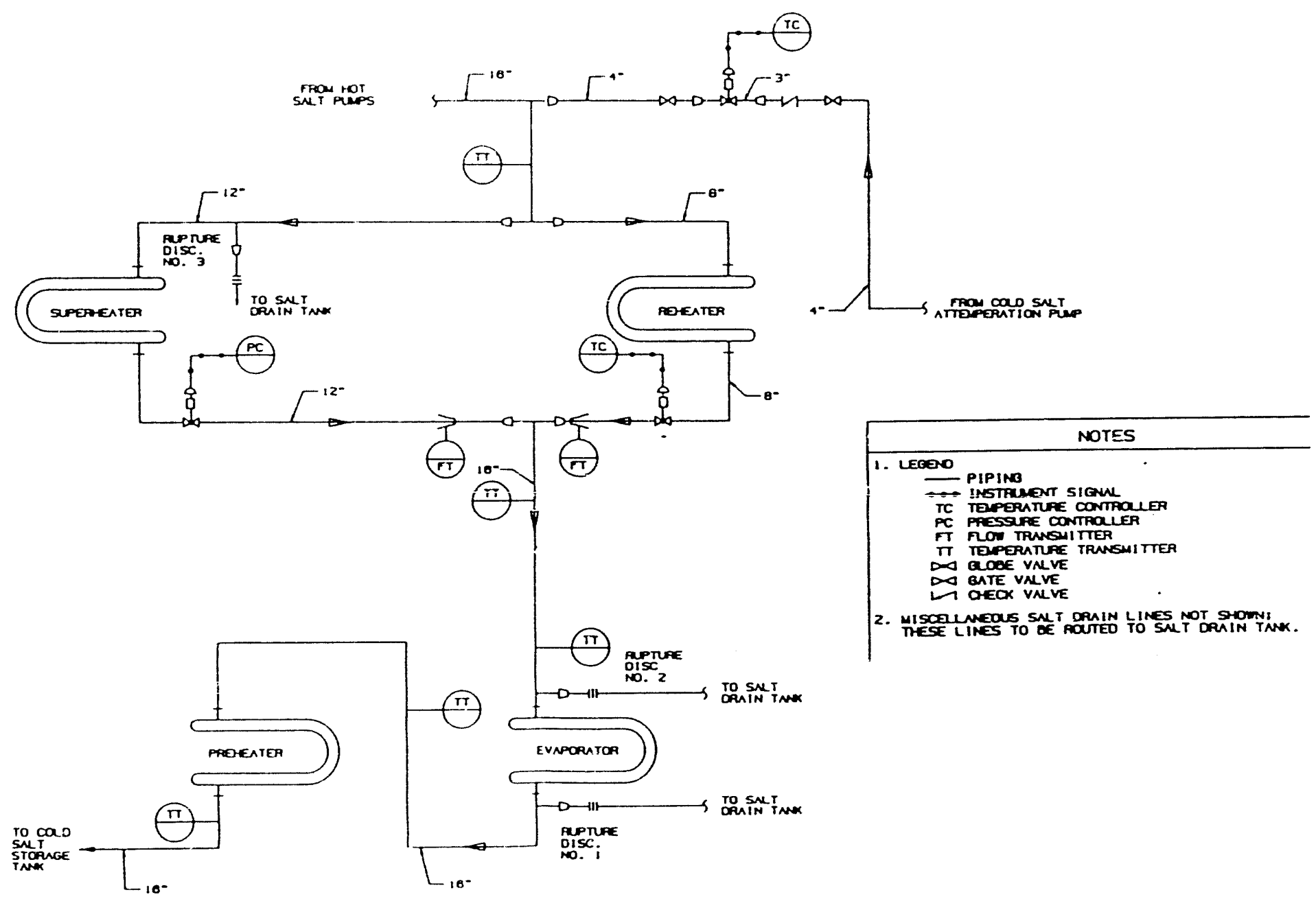

Figure 3-4 B\&W / SAIC Steam Generator Flow Schematic (Salt Side) 


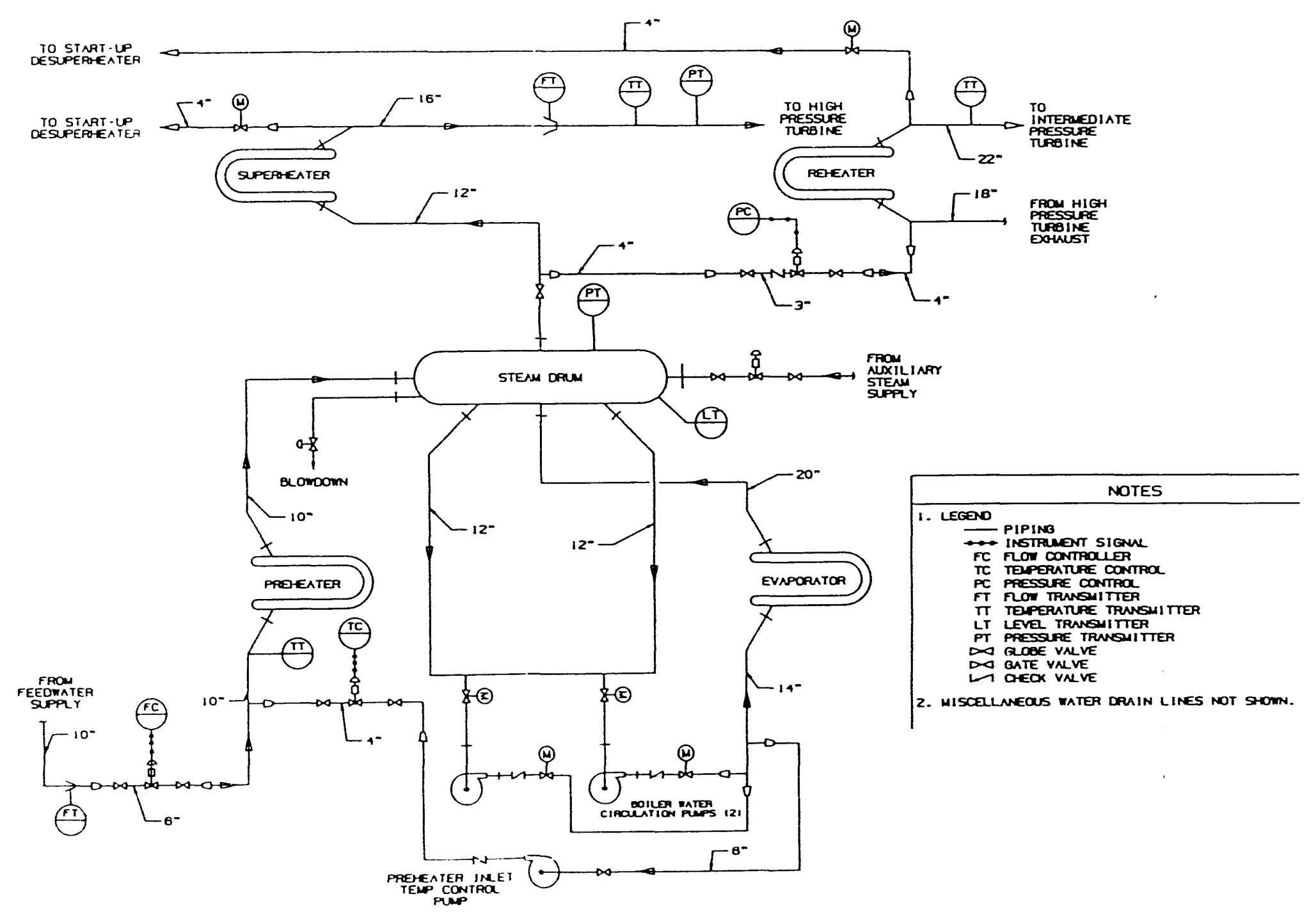

Figure 3-5 B\&W / SAIC Steam Generator Flow Schematic (Water/Steam Side) 


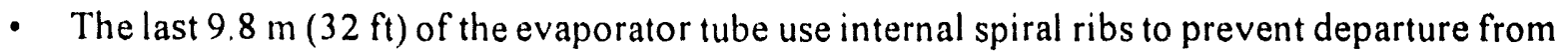
nucleate boiling in the tube sections with high quality steam

- The evaporator uses recirculation pumps to maintain adequate water/steam flow rates in the tubes

- An elevated steam drum provides saturated water to the recirculation pumps at the required suction head, and dries the saturated steam flowing to the superheater.

It can be noted that the only nitrate salt steam generator built to date for solar applications was the Babcock and Wilcox $3 \mathrm{MWt}$ U-tube/U-shell design installed in the Molten Salt Electric Experiment at the Central Receiver Test Facility in Albuquerque, New Mexico.

\section{VESSEL SHELL THICKNESSES AND WEIGHTS}

A comparison of the steam generator vessel shell thicknesses and weights is shown in Table 3-3.

Table 3-3

COMPARISON OF STEAM GENERATOR VESSEL SHELL THICKNESSES ${ }^{\prime}$ AND WEIGHTS ${ }^{2}$

\begin{tabular}{|c|c|c|c|c|c|c|c|c|}
\hline \multirow{2}{*}{ Preheater } & \multicolumn{2}{|c|}{ ABB Lumuus } & \multicolumn{2}{|c|}{ Strullers Wells } & \multicolumn{2}{|c|}{ Foster Whecler } & \multicolumn{2}{|c|}{ B\&W / SAIC } \\
\hline & & & & & & & & \\
\hline - Thickness & 13 & (0).5(1) & 111 & $(4.375)$ & 25 & $(1.0)$ & 13 & $(0.5)$ \\
\hline - Weight & $43.0(0)$ & (9) 5 ()()()) & $52,600)$ & $(115.9(0)(0)$ & $54,0(0)$ & $(119,(000)$ & $35,700)$ & $(78,800)$ \\
\hline \multicolumn{9}{|l|}{ Evaporator } \\
\hline - Thichness & 156 & $(6.125)$ & 194 & $(7.625)$ & 25 & $(1.0)$ & 13 & $(0.5)$ \\
\hline - Wcightı & $170.110(1)$ & $(375,0(0)(0)$ & $218,(0)(1)$ & $(480,6010)$ & $122,0(0)(0)$ & $(269,(0)(0))$ & 78,400 & $(172,800)$ \\
\hline \multicolumn{9}{|l|}{ Stcam drum } \\
\hline - Thickness & 156 & $(6.125)$ & 194 & $(7.625)$ & 171 & $(6.75)$ & 95 & $(3.75)$ \\
\hline - Woight & \multicolumn{2}{|c|}{ Wilh craporator } & \multicolumn{2}{|c|}{ Will craporator } & \multicolumn{2}{|c|}{ Will cvaporator } & 41,100 & $(90,500)$ \\
\hline \multicolumn{9}{|l|}{ Superheater } \\
\hline - Thickness & 37 & $(1.4375)$ & 1411 & $(5.5)$ & 19 & $(0.75)$ & 11) & $(0.375)$ \\
\hline - Weight & $97 .(1010)^{1}$ & $(214.010(1)$ & $6.5 .3(1)(1)$ & $(1+4.0(1)(0)$ & 28.50() & $(62.80(1))$ & 12,100 & $(26,700)$ \\
\hline \multicolumn{9}{|l|}{ Relicater } \\
\hline - Thichness & (1) & $(2.375)$ & 38 & (1.5) & 19) & (0).75) & 16 & $(0.625)$ \\
\hline - Woight & 57.01110 & $(126.1)(1))$ & 0.2 .2010 & $(1.37 .1010)$ & $20,9(10)$ & $(46,0)(1))$ & $12,7(1)$ & $(28,100)$ \\
\hline lal & $4(0+.0(1)(1)$ & $1.024 .0(0)(1)$ & 398.1001 & $(877,6(0))$ & $225,4(1)$ & $(496,800)$ & $\mid 80,0(0)$ & $(396,90(1)$ \\
\hline
\end{tabular}

Notes:

1) $\mathrm{mm}$ (in.)

2) Dry woight, without insulation: hg (lb)

3) Approximate: weights shown are those in Rel. 2-1

4) Weight for I of 2 superheaters 
The ABB Lummus, Foster Wheeler, and B\&W / SAIC preheater designs place the high pressure water on the tube side, while the Struthers Wells approach places the low pressure nitrate salt on the tube side. The theoretical weight advantage is realized in the ABB Lummus and B\&W / SAIC designs, but it is not apparent in the Foster Wheeler approach.

The ABB Lummus and Struthers Wells kettle evaporators place the high pressure water-steam mixture on the shell side, while the Foster Wheeler and B\&W / SAIC designs place the nitrate salt on the shell side. As expected, the kettle evaporators are considerably heavier than the designs in which boiling occurs in the tubes.

The ABB Lummus, Foster Wheeler, and B\&W / SAIC superheater designs place the high pressure steam on the tube side, while the Struthers Wells approach places the low pressure nitrate salt on the tube side. The theoretical weight advantages are realized in the Foster Wheeler and B\&W / SAIC designs, but the total weight of the $2 \mathrm{ABB}$ Lummus heat exchangers is three times that of the Struthers Wells superheater. Some of this difference may be attributed to the large tubesheets in the ABB Lummus design; they are $2.1 \mathrm{~m}(82 \mathrm{in}$ ) in diameter and $660 \mathrm{~mm}(26 \mathrm{in}$.) thick.

In a manner similar to the evaporators, the ABB Lummus and Struthers Wells reheaters place the high pressure steam on the shell side, while the Foster Wheeler and B\&W / SAIC designs place the nitrate salt on the shell side As with the evaporators, the ABB Lummus and Struthers Wells heat exchangers are considerably heavier than the other two designs

As shown by the column totals in the table, the weight of the kettle boiler designs is approximately twice that of the Foster Wheeler and B\&W / SAIC designs

\section{STARTUP TINIES}

Startup times from cold and warm conditions for each of the steam generators are summarized in Table $3-4$

Table $3-4$

STARTUP TIMES FROM COLD AND WARM CONDITIONS'

$\begin{array}{lcc}\quad \text { Vendor } & \text { From Cold } & \text { From Warm } \\ \text { ABB Lummus } & \text { Not specified } & 0.5 \text { to I } \\ \text { Struthers Wells } & 10 & \text { Less than } 5 \\ \text { Foster Wheeler } & 10 & 1 \\ \text { B\&W / SAIC } & 4 & \text { Less than I }\end{array}$

Notes:

1. Time, in hours, to normal operating conditions; a cold startup is from ambient temperature; a warm startup follows an overnight shutdown

2. Conservative value in lieu of transient thermal analysis; shorter times are likely 
Estimates of the times required to heat the steam generator from ambient temperature to normal operating conditions ranged from 4 to 10 hours. These times are of interest to the plant operators, but have a limited influence on the feasibility assessment. This is because the steam generator is allowed to cool to ambient perhaps only once or twice a year, and the startup times and energies will have little influence on annual plant performance.

Following an overnight shutdown, the estimates of startup times ranged from 1 hour to approximately 5 hours. These times are of more interest, because daily startup times and energies can have a measurable influence on the annual performance. Intuitively, the heat exchanger designs which put the low pressure salt on the shell side, and thereby minimize shell thicknesses, should offer the best transient response. However, this is not borne out by the vendor responses. A review of the table shows that one steam generator with a kettle evaporator (ABB Lummus) has a comparable startup time to the steam generators which exclusively place the low pressure salt on the shell side (Foster Wheeler and B\&W / SAIC). Furthermore, the Struthers Wells startup time was based on a conservative temperature ramp rate $(56 \mathrm{C} / \mathrm{hr}(100 \mathrm{~F} / \mathrm{hr}))$, which was known to result in acceptable thermal stresses. Struthers Wells stated that a shorter startup time is likely, but a detailed transient analysis would be required to determine the minimum.

It should also be noted that the steam generator startup times may not govern the startup time for the turbine plant. In particular, main and reheat steam temperature ramp rates in the steam generator must meet the allowable ramp rates specified by the turbine manufacturer $A$ survey of turbine designs on recent cogentration and utility projects at Bechtel showed the following:

- Small (20 to $40 \mathrm{MWe}$ ) non-reheat turbines designed for cyclic service can be started following an overnight shutdown in approximately 0.5 hours. The turbines use separate high pressure and low pressure sections to achieve this transient performance. The size of the high pressure section is held to a minimum by operating at a high speed (10,000 rpm). A step-down gearbox connects the high speed section to the $3,600 \mathrm{rpm}$ low pressure section and generator. The high pressure section also uses a vertical split case with separate inner and outer sections to minimize the thermal mass

- Large (100 10 $200 \mathrm{MWe}$ ) reheat turbines designed for base load service generally require at least 2 hours for startup following an overnight shutdown. The principal rate limitations are imposed by the thick metal sections where the horizontally-split upper case joins the lower case The design features noted above for small, cyclic duty turbines are not currently available in large turbines. However, the transient performance can be improved by incorporating features found in some European turbines designed for cyclic service. Specifically, electric or steam trace heating can be added to the case joint to reduce the startup times

The startup times for ABB Lummus, Foster Wheeler, and B\&W / SAIC steam generators are no longer, and may be shorter, than typical startup times for the turbine generator. This may also be true for the Struthers Wells design, depending on the results of further thermal analysis. Thus, all of the designs should be equally acceptable for commercial service. 


\section{ADVANTAGES AND DISADVANTAGES}

Some of the qualitative advantages and disadvantages of each of the three heat exchanger concepts are discussed below in Table 3-5.

Table 3-5

HEAT EXCHANGER CONCEPT ADVANTAGES AND DISADVANTAGES

\begin{tabular}{|c|c|c|c|}
\hline Item & Straight tube/straight shell & U tube/straight shell & U tube/U shell \\
\hline Design & $\begin{array}{l}\text { Less complex thermal } \\
\text { analysis; more complex } \\
\text { structural analysis } \\
\text { (bellows) }\end{array}$ & $\begin{array}{l}\text { More complex thermal } \\
\text { analysis (tubesheet) }\end{array}$ & $\begin{array}{l}\text { Less complex thermal } \\
\text { and structural analyses }\end{array}$ \\
\hline Fabrication & $\begin{array}{l}\text { Least complex, if } \\
\text { bellows is available }\end{array}$ & $\begin{array}{l}\text { Average complexity } \\
\text { Thick shell wall } \\
\text { (if high pressure) }\end{array}$ & $\begin{array}{l}\text { More complex } \\
\text { (U bend closure) }\end{array}$ \\
\hline Operation & $\begin{array}{l}\text { Heat exchangers } \\
\text { tolerant of rapid } \\
\text { temperature } \\
\text { changes, but limited } \\
\text { by steam drum or } \\
\text { bellows }\end{array}$ & $\begin{array}{l}\text { Less tolerant of } \\
\text { temperature changes, } \\
\text { but limits may be } \\
\text { set by turbine }\end{array}$ & $\begin{array}{l}\text { Heat exchangers } \\
\text { tolerant of rapid } \\
\text { temperature } \\
\text { changes, but limited } \\
\text { by steam drum }\end{array}$ \\
\hline Maintenance & $\begin{array}{l}\text { More complex if } \\
\text { bellows must be } \\
\text { removed }\end{array}$ & $\begin{array}{l}\text { Average complexity } \\
\text { for tube plugging }\end{array}$ & $\begin{array}{l}\text { Average complexity } \\
\text { for tube plugging }\end{array}$ \\
\hline Reliability & $\begin{array}{l}\text { Bellows may need } \\
\text { to be demonstrated }\end{array}$ & $\begin{array}{l}\text { Significant design, } \\
\text { fabrication, and } \\
\text { operating experience }\end{array}$ & $\begin{array}{l}\text { Good reliability shown } \\
\text { at MSEE, but test } \\
\text { duration was limited }\end{array}$ \\
\hline
\end{tabular}

It should be noted that all of the steam generator concepts are based on mature, commercial heat exchanger designs. The advantages and disadvantages noted above reflect relatively minor differences in complexity, and none of the approaches can be considered to be either clearly preferred or seriously disadvantaged.

The only area in which some reservations might be made is the requirement for bellows in the straight tube/straight shell concept. Foster Wheeler, in the 1982 study for Sandia National Laboratories, stated that sodium steam generators in European (SNR-300) and USSR (BN-600) 
nuclear breeder plants used expansion belluws in the shells. In addition, a Westinghouse sodium steam generator with bellows on the shell side of the heat exchanger is currently undergoing tests at the Rockwell International Energy Technology Engineering Center facility in Santa Susana, California. Nonetheless, a test program to demonstrate bellows reliability in nitrate salt service under moderate thermal cycling conditions may be required.

\section{WA RRANTY PROVISIONS}

The warranty provisions outlined by each vendor are presented in Table 3-6.

Table 3-6

COMPARISON OF STEAM GENERATOR WARRANTY PROVISIONS

ltem

First quality and

free from defects

Performance guarantee

Repair after initial

service date

Repair after

delivery date

Liability for storage, operation, maintenance. crosion, corrosion, or alterations

Liability for consecpuential damages

Guarantee for fitness for a particular purpose

\begin{abstract}
ABB L.Ummus
\end{abstract}
Yes

Not discussed

12 months

18 months
Responsibility
of project
Responsibility
of project
Responsibility
of project

Not discussed Not discussed

18 months

18 months

Not discussed

Could be

provided

12 months

12 months

None stated

Nol discussed
Responsibility
of project

Not

guaranteed
Responsibility
of project

Not guaranteed guaranteed
Responsibility of project
Not discussed

The provisions among the vendors are quite comparable, and indicate that the heat exchangers and auxiliary equipment will be commercial items supplied on a competitive basis. 


\section{CAPITAI, COST ESTIMATES}

The capital cost estimate for each steam generator consists of two elements: the investment cost for design, procurement, and installation, and the operating cost for the hot salt pumps to overcome the pressure drop through the heat exchangers. The later element can be converted to an equivalent capital cost to assist in the assessment of the four designs.

\section{Design, Procurement, and Installation Cost Estimates}

Design, procurement, and installation costs for the four steam generator designs are shown in Table 3-7. Several itents are apparent from a review of the table. First, the Struthers Wells and B\&W / SAIC estimates included not only the heat exchangers, but also the supporting items required for a complete steam generation system. These items included the inter-heat exchanger piping, insulation, trace heating, instrumentation, valves, structural steel, engineering, installation, and contingency. In contrast, the $\mathrm{ABB}$ Lummus and Foster Wheeler estimates included only the 4 heat exchangers, other shop costs, engineering, contingency, and fee

Second, a comparison of the heat exchanger costs, presented in Table 3-8, shows reasonably good correlations among heat exchange areas, shell side fluids, weights, and unit costs. Specilic observations include the following

- Preheater - The unit weight costs from ABB L .ummus and Struthers Wells are approximately $1 /$ those from Foster Wheeler and $B \& W / S \wedge I C$. The relatively complex fabrication of the $U$-shell in the B\&W / SAIC design may account for its high unit costs (this is also the case for the BSE / SAIC evaporator, superheater, and reheater) However, the Foster Wheeler straight tube/straight shell should, in theory, be the least complex to fabricate, but this is not reflected in the estimates

- Evaporator - The ABB Lummus and Struthers Wells evaporators are approximately twice as heavy as the foster Wheeler and B\&W / SAIC designs. This is a consequerice of placing the high pressure water/steam on the shell side. However, there is not a cost penalty for doing so; the kettle evaporators are competitive with the other designs The Foster Wheder unit costs are also noticeably higher than the costs from the other vendors This may be a consequence of integrating the steam drum with the evaporator

- Superheater - To limit the temperature change across the tubesheet, the ABB l.ummus design splits the superheater into two shells, and Struthers Wells places the high pressure steam on the shell side. The consequences are evident. The surface areas are $1 \frac{1}{2}$ to 3 times the Foster Wheeler and B\&W / SAIC requirements and the heat exchanger weights are 2 to 16 times as high. However, the unit area costs are competitive with the foster Wheeler cost and only 60 percent greater than the B\&W / SAIC estimate. This may be traced to the use of standard commercial heat exchanger designs by $A B B$ L.ummus and Struthers Wells

The unit weight cost of the $A B B$ Lummus heat exchanger is only $1 / 3 \%$ that of the other designs, which can perhaps be attributed to the large tubesheets noted above in the

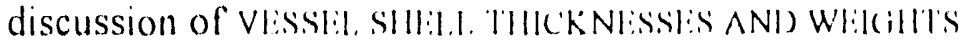


Table 3-7

COMPARISON OF STEAM GENERATOR COST ESTIMATES

DESIGN, PROCUREMENT.

\section{AND INSTALLATION COST}

- Preheater

- Evaporator

- Steam drum

- Superheater

- Reheater

- Recirculation pumps

- Other shop costs

- Salt Piping and Attemperators

- Steam Piping

- Insulation

- Trace Heating

i - Preheat System

- Instrumentation and Valves

- Support Steel

- Engineering

- Shipping

- Installation

- General Activities

- Contingency

- Home office costs

- Construction management

- Fee

Total

\section{ABB Lummus}

$\$ 370.000$

$\$ 1.230 .000$

Not applicable

S1.950,000

$\$ 600,000$

Vot applicable Included in total Not included

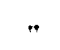

$\cdots$

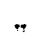

"

$\cdot$

Included in total

Not included Included in total
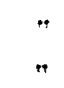

$+$

$$
+
$$

$\$ 4.150 .000(5)$
Struthers Weils

$\$ 415,000$

$\$ 1,125,000$

Not applicable

$\$ 1,979.000$

$\$ 1,668,000$

Not applicable Included in total

$\$ 117,000$

$\$ 138,000$

$\$ 47.000$ (1)

$\$ 110,000$

$\$ 181.000$

$\$ 246,000$

$\$ 52,000$

Included in total

$\$ 53.000$

Included in total

$"$

.

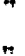

$\$ 6.131,000$
Foster Wheeler

B\&W SAIC

$\$ 690,000$

$\$ 935,000$

$\$ 240,000$

$\$ 450,000$

$\$ 550,000$

$\$ 539.000$

Included in total $\$ 719,000$ (2)

Not included

n

n

n

$n$

"

$n$

$\$ 600,000$

Not included

$n$

Included in total

$\$ 971,000$ (3)

Included in total

Not included

$\$ 466,000$ (4)

$\$ 6,291,000(6)$
Not included $\$ 193,000$ (2)

$\$ 213,000$

Not applicable $\$ 503,000(2)$

$\$ 560,000(2)$

$\$ 1,215,000$

$\$ 80,000$

$\$ 299,000$

$\$ 286,000$

$\$ 1,121,000$ Included in total

$\rightarrow$

$\$ 8,593,000$
1) Includes insulation and heat tracing

2) Includes installation labor costs

3) 20 percent of above costs
4) 8 percent of above costs

5) Cost for partial system; $\$ 7,400,000$ estimated cost for complete system

6) Cost for partial system: $\$ 9,500,000$ estimated cost for complete system 
Table $3-7$ (Continued)

COMPARISON OF STEAM GENERATOR COST ESTIMATES

\section{OPERATING COST}

ABB Lunmus

Hot Salt Pumps

- Flow rate, lb sec

- Pressure drop. $\mathrm{ft}$

- Power demand. $k$ We 47 )

- Annual energy demand. $k$ the $(8)$

- Annual energy cost (9)

- Equivalent capital cost 110 ;

Evaporator Recirculation Pump

- Flow rate. Ib sec

- Pressure drop, ft

- Power demand. kWe (11)

$\vec{i} \quad$ - Annual energy demand. $k$ Whe $(s)$

- Annual energy cost (9)

- Equivalent capital cost 1101

TOTAL OPERATING COST

$$
\begin{array}{r}
1.179 \\
123 \\
280 \\
980.000 \\
5107.000 \\
51.019 .000
\end{array}
$$

Not required

Struthers Wells

Foster Wheeler

$B \& W$ SAIC

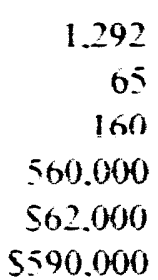

Not required

$\$ 590,000$

$\$ 6.721,000$

1,364
166
430
$1,505,000$
$\$ 166,000$
$\$ 1,581,000$

Not required

$\$ 7,872,000(12)$

$\$ 11,100,000(13)$

INSTALLSIGN. PROCUREMENT

7) Based on pump efficiency of 78 percent. motor efficiency of 95 percent. and variable speed drive efficiency of 96 percent.

8) Based on annual operating time of 3.500 hours

9) Based on auxiliary energy cost of $\$ 0.11 \mathrm{k}$ the

10) Based on levelized capital carning charge ifixed charge ratel of 10.5 percent

11) Based on pump efficiency of 70 percent and motor efficiency of 92 percent

12) Heat exchangers plus operatıng cost only

13) Estımated cost for complete sistem plus eperatıng cost 
Table $3 \cdot 8$

COMPARISON OF HEAT EXCHANGER UNIT COSTS

llem!

Preliealer

- Heat exchange area, $m^{2}$

- Shell side fluid

- Weight, kg

- Cost estimate

- Unir costs

$\$ / \mathrm{II}^{2}$

$\$ / k g$

livaporator and steam drum

- Heat exchange area, m

- Shell side Muid

- Weight, kg

- cost estimate

- llinil costs

$\$ / 111$

$\$ / k \underline{M}$

Superheiter

- Heal exchange area, m

- Shell side fluid

- Nought, kg

- cost estmmate

- llilit costs

$\$ / m$

$\$ h \underline{1}$

Rehenaler

- Hear exchange arear m

- Shell side fluid

- W'enght, k!

- Cost cistlmate

- Unir costs

$\$ / 11$

$\$ / k g$
ABB L.ummus

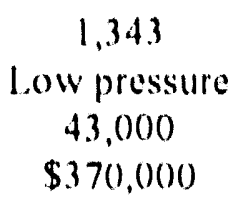

280

86

$$
1,550
$$

High pressure

170,000

$\$ 1,230,000$

790

72

1,102

l.ow pressure

$10.4,(0)(0)$

$\$ 1,95(1,0(0)$

$$
\begin{aligned}
& 1,680 \\
& 100
\end{aligned}
$$

1,0006

lligh pressure

$57,(1)(1)$

$\$(0)(0,00)$

(3)()

105
Struthers Wells

Foster Wheeler'

B\&W / SAIC:

1,320
High pressure
52,600
$\$ 41,5,000$

$$
\begin{gathered}
1,959 \\
\text { Low pressure } \\
54,000 \\
\$ 1,515,000
\end{gathered}
$$

770)

28.1

390

22.2

310

7.9
2,288

High pressure

218,000

$\$ 1,125,000$

490

52

1,596

lligh pressure

$0.5,300$

$\$ 1,979,000$

1.270

303

1,568

576

1,530

231

827

Low pressure

28,500

$\$ 1,087,000$

1,310

381

(1) 20

428
2.152

Low pressure

119,400

$\$ 1,351,000$

630

11.3 
- Reheater - The consequences of placing the high pressure steam on the shell side of the $A B B$ Lummus and Struthers Wells reheaters are evident The surface areas are 2 to 3 times the Foster Wheeler and B\&W / SAIC regunrements, and the heat exchanger weights are 3 to 5 times as high. However, this pattern does not hold for the unit costs

Third, a comparison of the estimates from BEW / SAIC and Struthers Wells shows wide variations in the costs for salt piping, insulation. heat tracing, instrumentation, engineering, and installation For example, the figures for engmeering and installation vary by factors of 25 and 6 , respectively These two costs may reflect extensive experience at Struthers Wells in the design, fabrication, and Installation of similar heat exchangers, while the higher B\&W / SAIC estimate may be an indication thall only one of this type has been fabricaled Alernately, the higher BeW / SAIC estimate may reflect a more extensive background with, and a more horough knowledge of, the costs associated with nitrate salt systems Nonetheless, the Struthers Wells estimate is probably optimustic in several areas for example. the surface area of the heat exchanger shells is approximately $370 \mathrm{~m}^{2}(4,000$ fit) and the estimated cost for msulaton and heat tracing is $\$ 7.000$ This is equivalent to a unit cost of $\$ 125 / \mathrm{m}^{\circ}\left(\$ 12 \mathrm{fi}^{\circ}\right)$ In comparison, typcal insulatlon costs (without heat tracing) used by Becheel

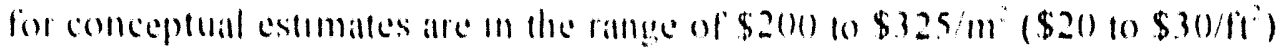

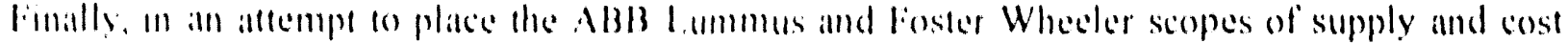
estlmatles onl the satme basss as the orher vendors, costs were added for the following salt prping and

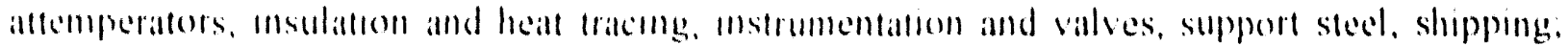

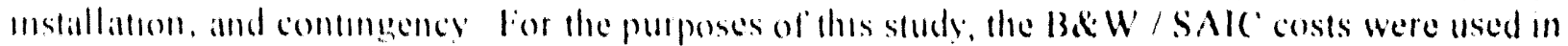

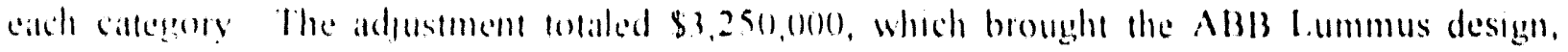

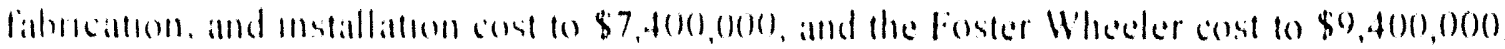

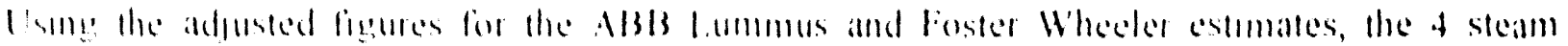

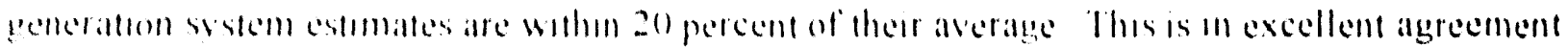

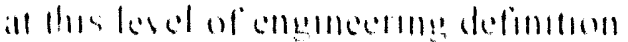

\section{Opriating ( ost fistimbates}

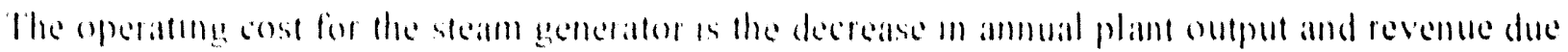
to the amsilatry electroc demand of the followme pumps

- Ilot sall pumper to overcome the pressute drop through the heall exchangers

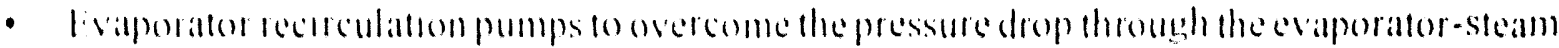

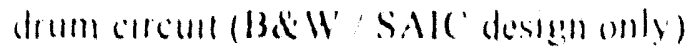

The operatmg cost was converted to an equnvalent caphtal cost, and hus cost added to the design, procurement, and installatton cost, to evaluate the overall ecomomes of each design

The hot salt pump ausiliary power demand was calculated using the following

- Salt flow rate and heat exchanger pressure drops as stated an each vendor report 
- A control valve pressure drop of $8.5 \mathrm{~m}$ ( $28 \mathrm{ft}$ ), as listed in the B\&W / SAIC report, was used ill all stean generator systems for consistency

- Pump efficiency of 78 percent, motor efficiency of 95 percent, and a variable speed drive efficiency of 96 percent

The hot salt pump power demands included $160 \mathrm{kWe}(215 \mathrm{hp})$ for the Struthers Wells steam generator, $280 \mathrm{kWe}(375 \mathrm{hp})$ for $\mathrm{ABB}$ Lummus, and $430 \mathrm{kWe}(575 \mathrm{hp})$ for Foster Wheeler and B\&W / SAIC.

The B\&W / SAIC evaporator recirculation pump demand was calculated using the following:

- Recirculation flow ritte of $46.4 \mathrm{~kg} / \mathrm{sec}(368,000 \mathrm{lb} / \mathrm{hr})$

- Total developed heid of $2.3 \mathrm{~m}$ (7.5 fi) to compensate for the $1.38 \mathrm{kPa}$ (20 psi) pressure drop in the evalporittor

- Pump efficiency of 70 percent and a motor efficiency of 92 percent

This resulted in a pump power demand of $16 \mathrm{kWe}(21 \mathrm{hp})$

A summary of the anmual energy demand and operating costs for the four steam generator designs is shown in Tiable 3.7 The operating costs were converted to equivalent capital costs using the

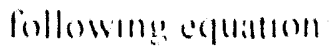

Equivalent Capitul Cost

Llectric energy demand - Marginal electric energy cost - Annual operating time Levelized Capital Carrying Churge

where

- The margmal cost of electric energy is assumed to be $\$ 011 / \mathrm{k}$ Whe This as the levelized cost of encrgy developed for the first commercial loo MWe plant in Phase I of the central receiver linlity studies (Rof 1-1)

- The annual operatmen mone of the hot salt pumps was assumed to be 3,500 hours

- The levelaced captal carrymg charge (fived charge rate) was 105 percent The rate, based on standard unlaty project financing and a constamt year dollar analysis, was that used during Phase I of the litility Studies

The results of the calculations are also shown in Table 3-7 The equivalent capital cost for operation ranged from o to 20 percent of the design, procurement, and installation cost. Thus, the pressure drop through the heat exchangers can influence the relative economics of competing designs. Note that the higher pressure drop in the foster Wheder and lie $W^{\prime}$ / SAIC designs entail an economic penalty of approximately $\$ \$()(0,00)$ relattive to the $A B B$ L.ummus design and $\$ 1,000,000$ relative to the Struthers Wells approach 


\section{Design, Procuement, Installation, and Openting Cost Estimutes}

The sum of the design, fabrication, installation, and operating cost estimates are also shown in table 3-7. From a review of the estimates, the following observations can be made

- There is good agreement annong the vendors regarding the costs of the heat exchangers, the divergence in the estimates occurs in the auxiliary equipment, engineering, and installation required for a complete system

- The subcontract price developed by Babcock \& Wilcox for the U-tube/U-shell steam generator in Phase 1 of the Utility Studies was $\$ 11,128,000$ (third quarter 1987 dollars). Escalating this price to first cuarter 1993 dollars using an annual rate of 4 percent yields an estimate of $\$ 13,800,000$ The steam generators developed for this study, including the Utube/U-shell approach, are considerably less expensive than the Utility Studies design. This may be attributed to the successful use of relatively lower cost kettle boilers in the Luz parabolic trough solar power plants, and renewed vendor interest in commercial central receiver projects following the start of the Solar Two Project

- It appears that a steam generator for a $100 \mathrm{MWe}$ commercial project can be fabricated and mstalled for approximately $\$ 8$ million 


\section{Section 4 \\ Thermal Storage System Hot Salt Tank Designs and Cost Estimates}

Three conceptual hot salt storage tank designs and cost estimates were developed during this study. Two of the designs, one developed by Chicago Bridge and Iron Technical Services Company (CBI) and a second by Pitt-Des Moines, Inc. (PDM), employed a stainless steel tank with external insulation The third design, developed by S. N. Technigaz (a French company), used a carbon steel tank with external insulation. To limit the carbon steel shell temperature to acceptable values, a layer of internal refractory insulation was required. In addition, a thin Incoloy liner was required to protect the refractory from the corrosive effects of the nitrate salt at $566 \mathrm{C}(1,050 \mathrm{~F})$.

The discussion which follows reviews the storage tank specification, design features, warranty provisions, and cost estimate for each of the concepts.

\section{SPECIFICATION}

The principal specifications used in the design of all of the tanks is presented in Table $4-1$. The nominal storage capacity is $1,560 \mathrm{MWht}$, which translates to an active volume of $7,690 \mathrm{~m}^{3}(272,000$ $\left.\mathrm{ft}^{2}\right)$ An inactive volume of salt at the bottom of the tank (heel) with a depth of $0.9 \mathrm{~m}(3 \mathrm{ft})$ was specified to minimize periodic thermai transients in the joint between the floor and wall. A $1.2 \mathrm{~m}$ $(f \mathrm{ft})$ high space at the top of the tank was also specified to hold the heel from the cold storage tank and the salt inventory in the receiver and thermal storage systems. Freeboard above the $1.2 \mathrm{~m}$ space, If any, was to be selected by the vendor to accommodate liquid movement during an earthquake A value of $\$ 1,700 / \mathrm{kW}$ was assigned to heat loss through the tank to assist the vendor in selecting the optumum insulation thicknesses.

Nitrate salt tanks operating at this combination of size and temperature have yet to be fabricated and tested However, several tanks have been built over the past several years that meet or exceed the ste or temperature reguirements of the hot salt storage tank. Representative tanks, with external insulation, include the collowing

- Four bitumen tanks, each $88 \mathrm{~m}(288 \mathrm{ft})$ in diameter and $15 \mathrm{~m}(48 \mathrm{ft})$ high, were fabricated for Bechtel at the Syncrude Tar Sands Project in Mildred Lake, Canada. The externally msulated tanks operated at 175 to $230(1350$ to $450 \mathrm{~F})$ and used forced air circulation to cool the foundations

- A nitrate salt tank. $14 \mathrm{~m}(45 \mathrm{ft}) \mathrm{in}$ diameter and $28 \mathrm{~m}(9 \mathrm{ft})$ high, was fabricated by CBI for a propretary chemical process plant in Texas. The externally insulated tank operates at 260 $10+50(1.500)$ to $8421 \%$ and uses natural convection air circulation to cool the foundation

- The thermal storage system for the L.uz Solar Electric Generating Station I parabolic trough solar powe plant near Barstow, (aliforma The cold tank, $210 \mathrm{~m}(69 \mathrm{ft})$ in diameter and $122 \mathrm{~m} \mathrm{(40} \mathrm{ft)} \mathrm{high,} \mathrm{stores} \mathrm{a} \mathrm{synthetic} \mathrm{oil} \mathrm{at} 250 \mathrm{C}(480 \mathrm{~F})$, and the hot tank, $22.1(72.5 \mathrm{ft})$ in diameter and $122 \mathrm{~m}(\mathrm{f}) \mathrm{ft})$ high, stores oil at $315 \mathrm{C}(600 \mathrm{~F})$ 
Table 4-1

HOT SALT TANK PERFORMANCE SPECIFICATION

Active tank volume

Additional tank volumes

Heel

Drain down from receiver and thermal storage systems

Freeboard

Nitrate salt density

Equivalent capital cost of heat loss through the insulation

Maximum temperature of insulation exposed to ambient

Heat tracing system

Leak detection system

Cooled foundation

Seismic accelerations

Wind loads

Soil bearing capacity
$7,693 \mathrm{~m}^{3}\left(271,674 \mathrm{ft}^{3}\right)$

$0.91 \mathrm{~m}(3 \mathrm{ft})$

$1.22 \mathrm{~m}(4 \mathrm{ft})$

To be selected by vendor

2.090-0.000636*(Temp, C); $\mathrm{g} / \mathrm{cm}^{3}$ (131.2-0.02221*(Temp, F); $\left.\mathrm{Ib}_{\mathrm{m}} / \mathrm{ft}^{3}\right)$

$\$ 1,700 / \mathrm{kWt}$

$60 \mathrm{C}(140 \mathrm{~F})$

Electric elements to be used at 50 percent of rating; spare circuit to be installed

To be specified by vendor

To be specified by vendor

API Standard 650 Zone 3

$40 \mathrm{~m} / \mathrm{sec}(90 \mathrm{mph})$ at $10 \mathrm{~m}$ above grade

$0.24 \mathrm{MPa}$ at $1.5 \mathrm{~m}$ below grade $(5,000$ psf at $5 \mathrm{ft})$

$0.48 \mathrm{MPa}$ at $3.0 \mathrm{~m}$ below grade $(10,000 \mathrm{psf}$ at $10 \mathrm{ft})$ 
- Oil and asphalt storage tanks for American Petrofina in Port Arthur, Texas. The cold tank, $45.7 \mathrm{~m}(150 \mathrm{ft})$ in diameter and $14.6 \mathrm{~m}(48 \mathrm{ft})$ high, operates at $175 \mathrm{C}(350 \mathrm{~F})$, and the hot tank, $24.4(80 \mathrm{ft})$ in diameter and $14.6 \mathrm{~m}(48 \mathrm{ft})$ high, operates at $260 \mathrm{C}(500 \mathrm{~F})$

- Oil and asphalt storage tanks for ARAMCO in Qasim, Saudi Arabia. The cold and hot tanks, operating at $175 \mathrm{C}$ and $220 \mathrm{C}(350 \mathrm{~F}$ and $430 \mathrm{~F})$, respectively, have dimensions of $57.9 \mathrm{~m}$ $(190 \mathrm{ft})$ in diameter and $4.6 \mathrm{~m}(15 \mathrm{ft})$ high

- Nitrite salt thermal storage tanks for the MRI / SOLERAS solar desalination plant in Yanbu, Saudi Arabia. The cold and hot tanks, operating at $250 \mathrm{C}$ and $315 \mathrm{C}(480 \mathrm{~F}$ and $600 \mathrm{~F})$, respectively, have dimensions of $4.9 \mathrm{~m}(16 \mathrm{ft})$ in diameter and $4.9 \mathrm{~m}(16 \mathrm{ft})$ high

- $112 \mathrm{MWh}$ thermal storage tank for the $10 \mathrm{MWe}$ Solar One pilot plant near Barstow, California. The tank operated on the thermocline principle, and contained 6,180 metric tons $\left(6,800\right.$ tons) of rock and sand and $910 \mathrm{~m}^{3}$ (240,000 gallons) of synthetic oil. During the charging cycle, oil entered the tank at $305 \mathrm{C}(580 \mathrm{~F})$, and during the discharging cycle, oil entered ar $220 \mathrm{C}(425 \mathrm{~F})$

The alternate tank design, using a low cost carbon steel shell with internal refractory insulation, has been proposed by Martin Marietta Corporation The liner concept was originally developed by Technigaz for liquified natural gas storage tanks, and has been successfully used in 15 ship and 20 shore facilities during the past 20 years. The idea was extended to high temperature nitrate salt storage by Martin Marietta Corporation and successfully tested in the $7 \mathrm{MWh}$ thermal storage system Subsystem Research Experiment at Sandia National Laboratories. The experimental tank, $3 \mathrm{~m}(10 \mathrm{ft})$ in diameter and $6.2 \mathrm{~m}(20.5 \mathrm{ft})$ high, operated at $566 \mathrm{C}(1,050 \mathrm{~F})$ and used forced water circulation to cool the foundation.

Thus, the extemally and internally insulated tank designs proposed in this study can be viewed as moderate extrapolations of current experience.

\section{DESIGN FEATURES}

Elevation drawings for the CBI, PDM, and Technigaz tank designs are shown in Figures $4-1$ through 4-3, respectively. The principal design features of the three concepts are summarized in Table 4-2

\section{Extemally Insulated Tanks}

As might be expected, the two externally insulated tank designs were quite similar. Each tank was $29.0 \mathrm{~m}(95 \mathrm{ft})$ in diameter, fabricated from 316 stainless steel, insulated with mineral wool, and supported at the walls by a perimeter ring wall. In addition, the foundations were cooled by air passages to limit the temperature of the natural soil, and the shell and floor plate thicknesses in one design were within 25 percent of the thicknesses in the other. The principal differences were as follows 


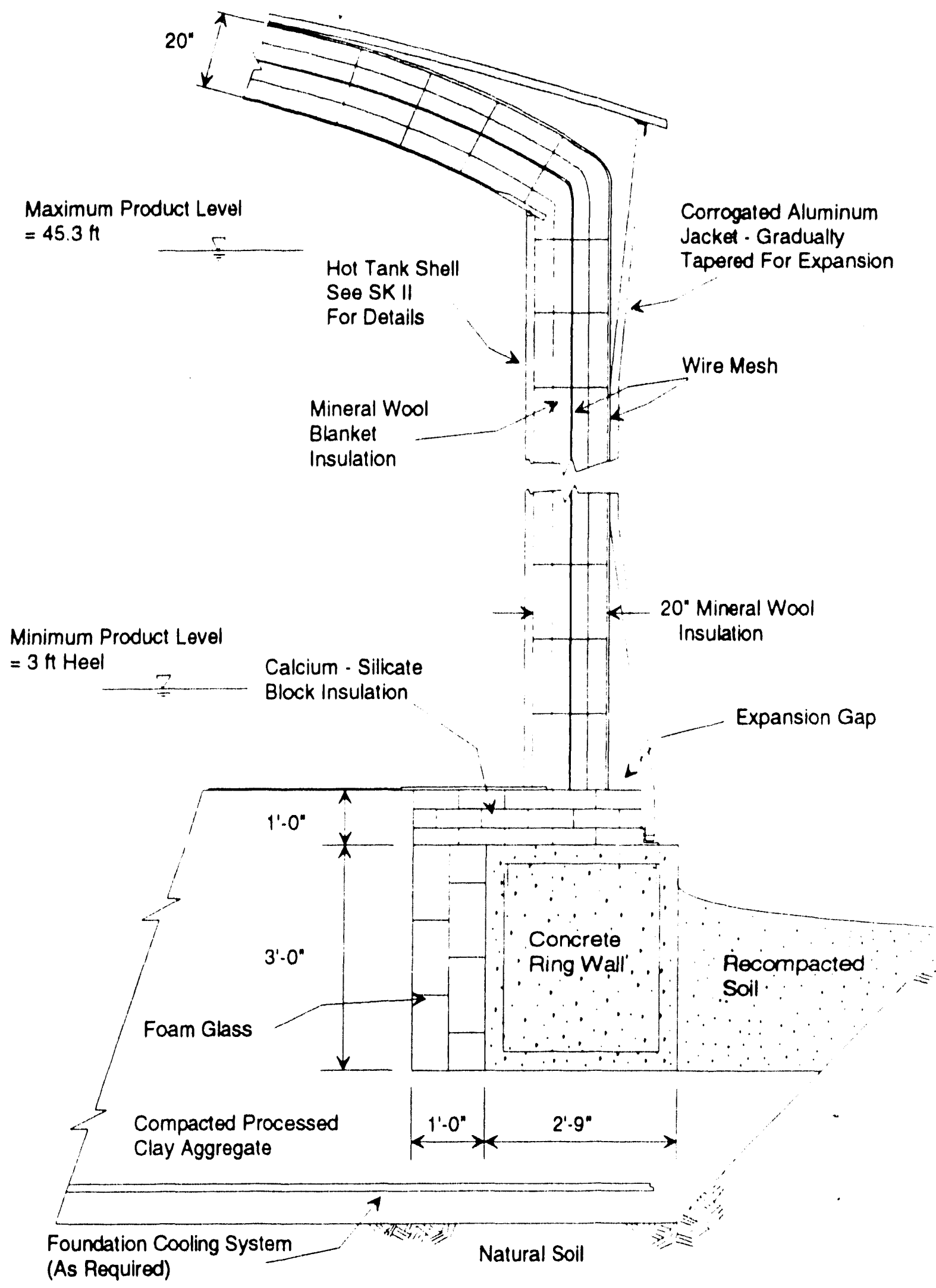

Figure 4-1 Chicago Bridge and Iron Hot Salt Tank Elevation Diagram (Sheet 1 of 2) 


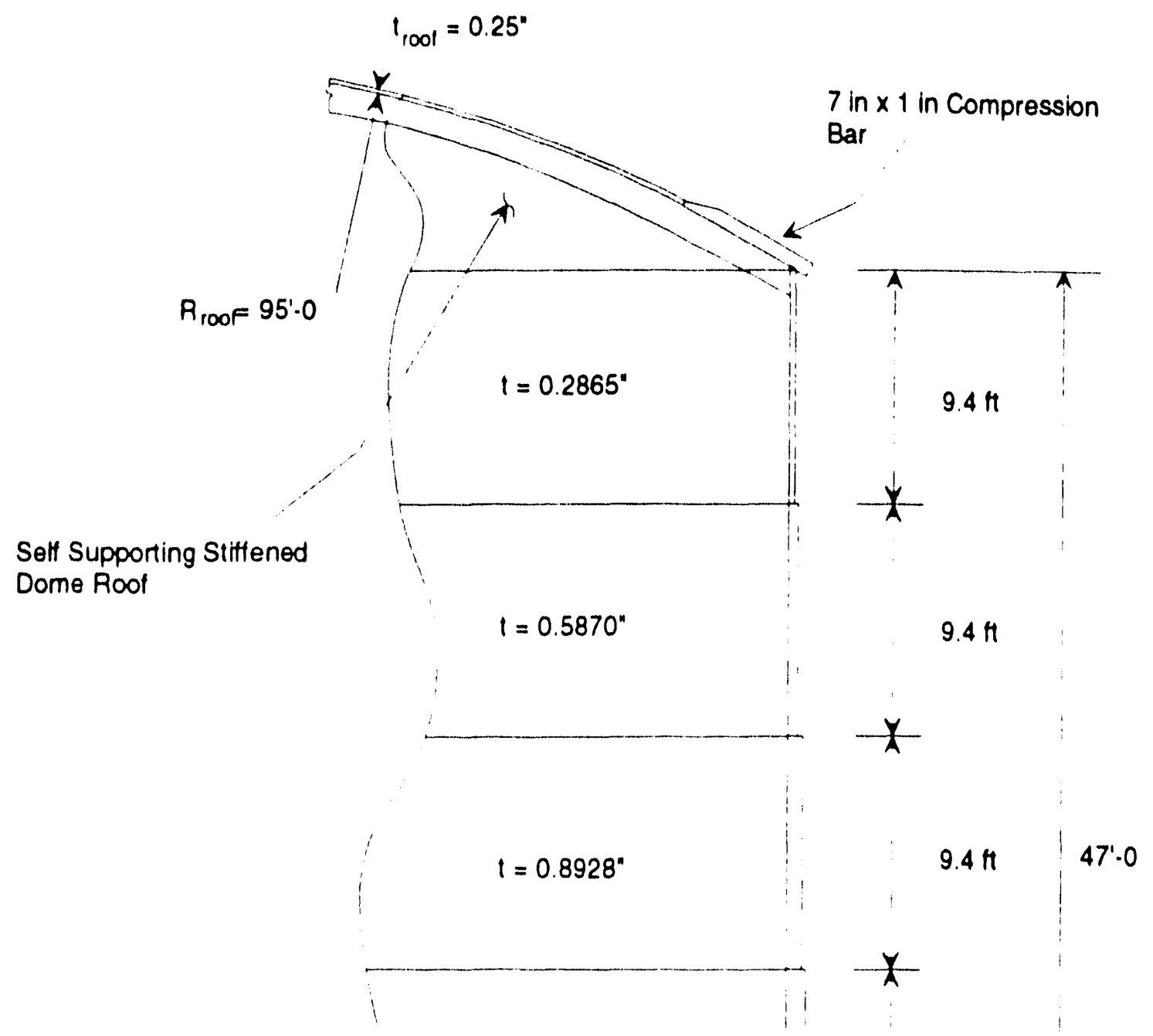

\section{Notes:}

1) Shell Mat'l : SA 240 - 316

$I=1.2012^{*}$

$9.4 \mathrm{H}$

2) Roof Mat'l : SA 240 - 316

3) Structural SA 240 - 304
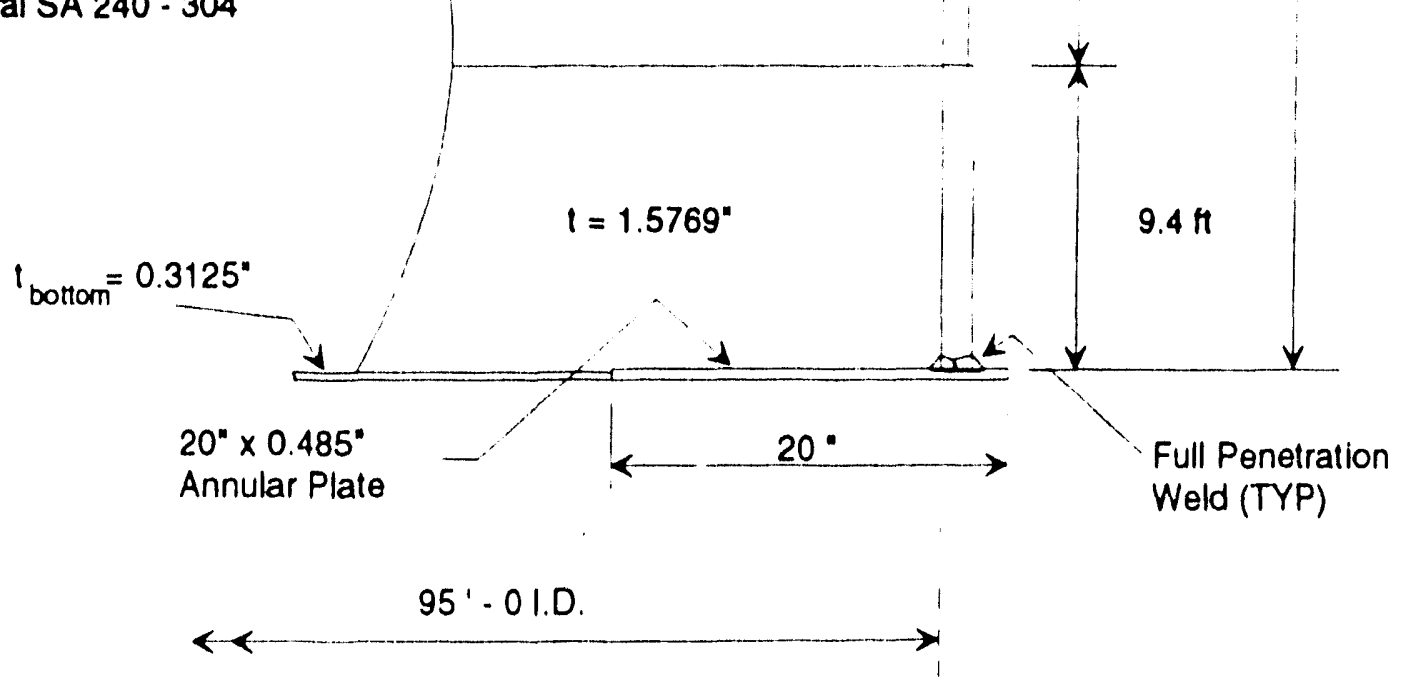

Figure 4-1 Chicago Bridge and Iron Hot Salt Tank Elevation Diagram (Sheet 2 of 2) 


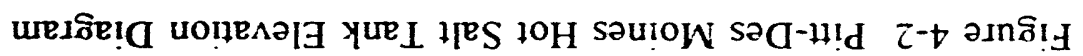

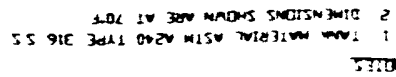

$$
\text { andats is }
$$

E secis ose ion jimsizs co

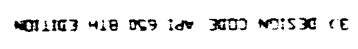

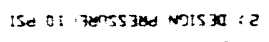

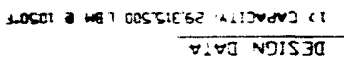

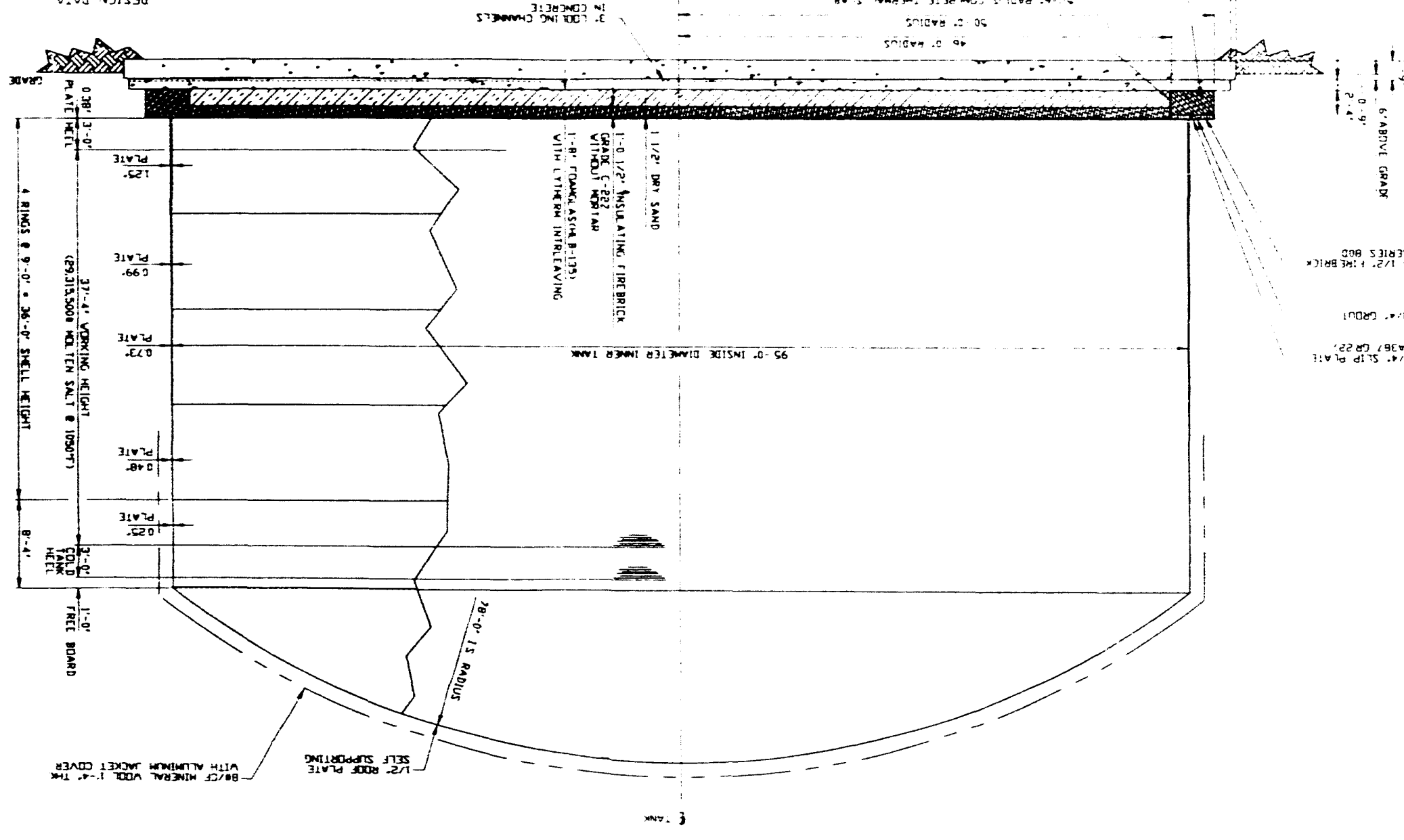

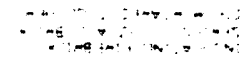

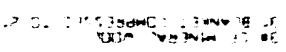

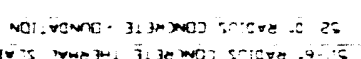

sntere is as 


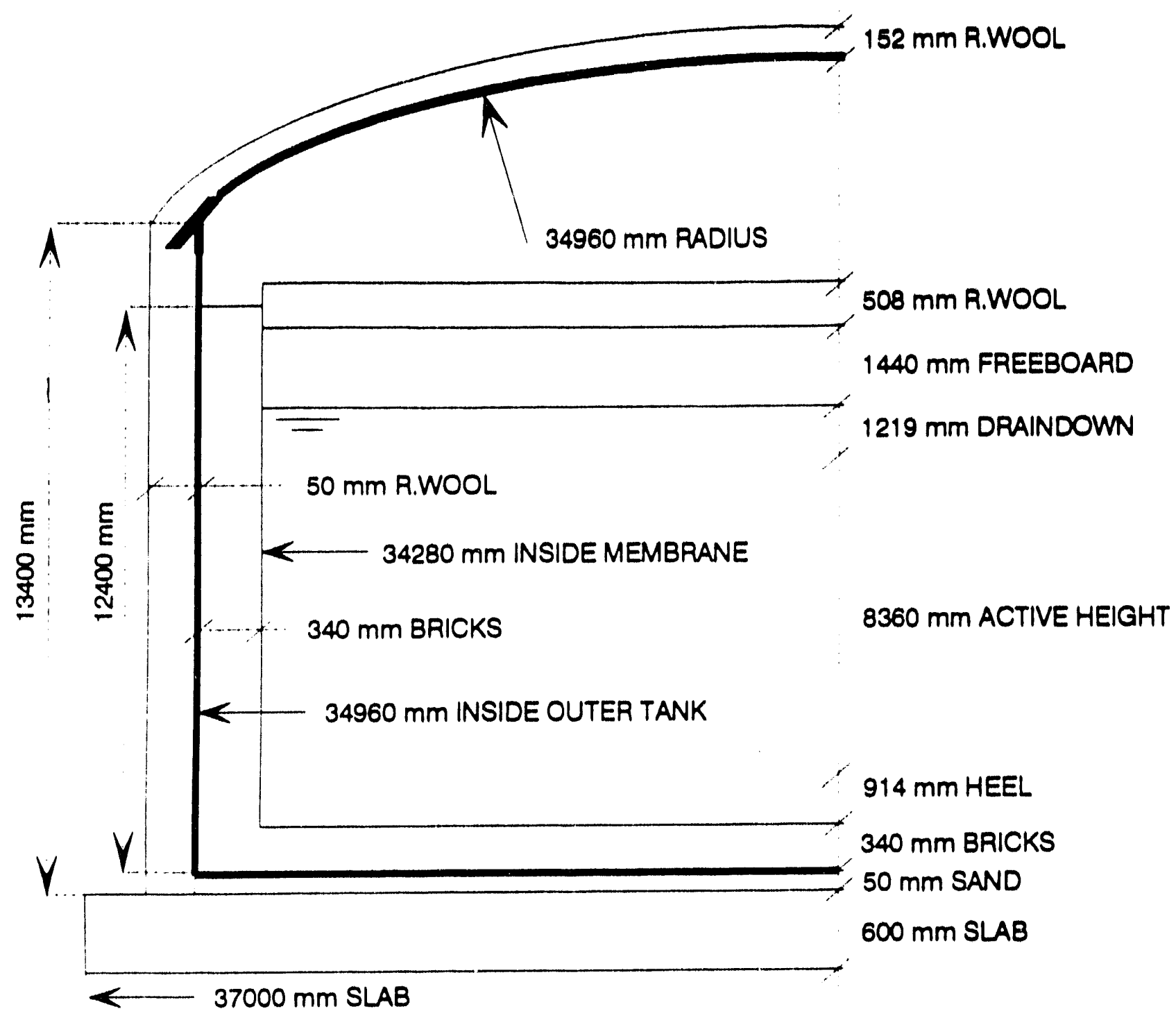

Figure 4-3 Technigaz Hot Salt Tank Elevation Diagram (Sheet 1 of 2) 


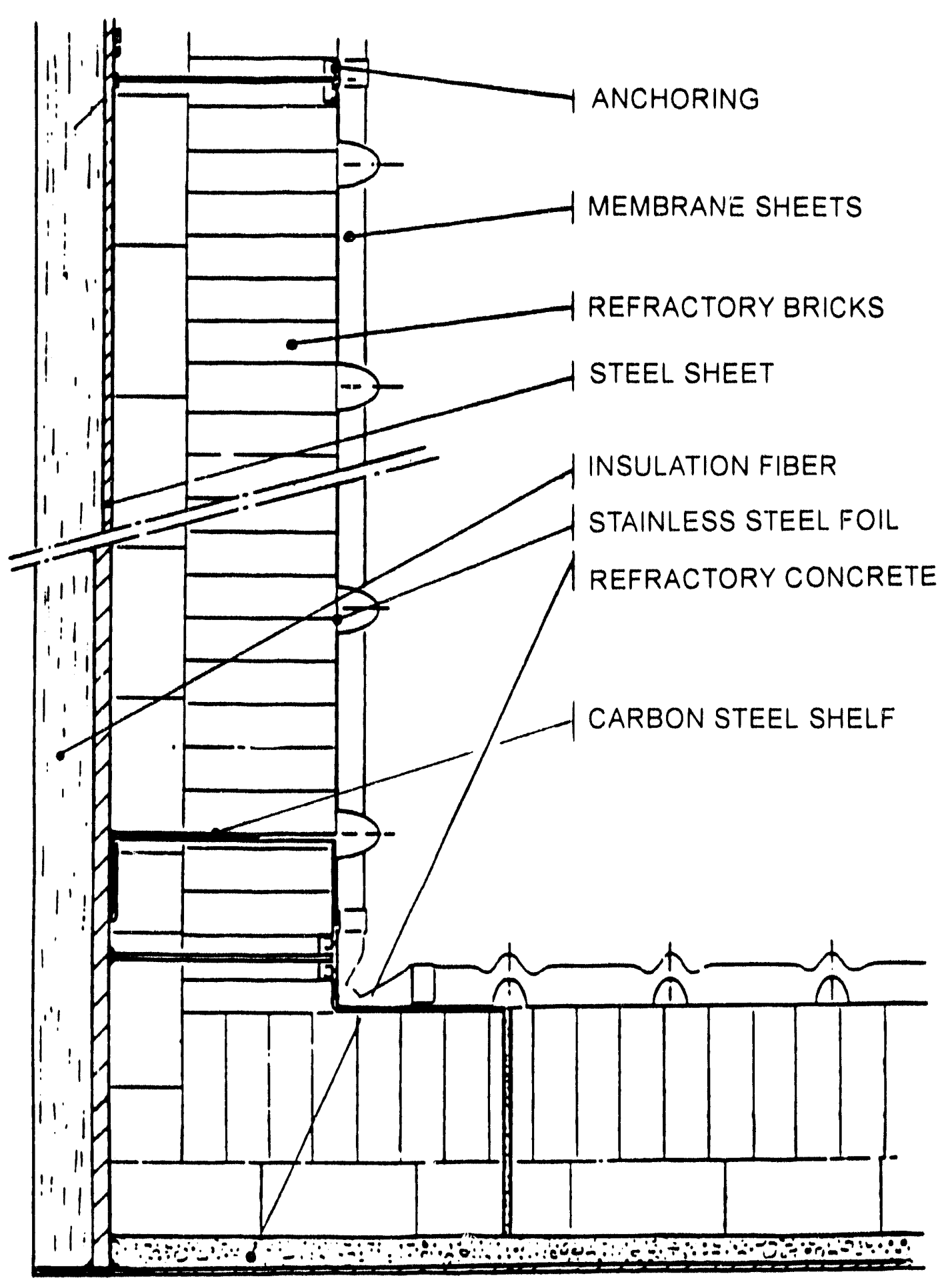

Figure 4-3 Technigaz. Hot Salt Tank Elevation Diagram (Sheet 2 of 2) 


\section{Table 4-2}

\section{COMPARISON OF HOT SALT TANK TECHNICAL CHARACTERISTICS}

\section{DIMENSIONS. ft}

- Outer tank diameter

- Innertank diameter

- Height

- Roof radius

PLATE THICKNESS, in.

- Roof

- Shell: top bottom

- Floor

MATERIALS

- Roof

- Shell

- Liner

- Floor

- Insulation

External

Internal

- Foundation (top to botrom) Perimeter

Calcium silicate block ( 12 in.)

Reinforced concrete ( 33 in. $W \times 36$ in. $H$ )

Foamglas ( 12 in. $W \times 36$ in. $H$ )

Center

Compacted local soil ( 48 in.)

Soil

\section{Chicago Bridec and Iron}

$$
\begin{gathered}
\text { Not applicable } \\
47.0 \\
450
\end{gathered}
$$

$$
\begin{array}{r}
0.25 \\
0.2 \times 65 \\
1.5769 \\
0.3125
\end{array}
$$

316 stainless sted

316 stainless steel

Not applicable

316 stainless steel

Roof and shell -

mineral wool ( 20 in.)
Nor applicable
Pitt-Des Moines

95.0

Not applicable

4.3

78.0

0.50
0.25
1.25
0.34

$\$ 16$ stainless steel

316 stainless steel

Not applicable

316 stainless steel

Roof and shell mineral wool ( 16 in.)

Not applicable

Steel slip plate ( $1 / 4$ in.)

Grout ( $3 / 4$ in.)

Firebrick ( 412 in.)

Insulating firebrick (28 in.)

Dry sand (1 $1 / 2$ in.)

Insulating firebrick (12 1.2 in.)

Foamgias ( 20 in.)

Thermal concrete ( 9 in.)

Reinforced concrete (21 in.)

Compacted local soil ( $\$$ s in.)
Technigaz

$$
\begin{array}{r}
114.8 \\
112.5 \\
4.0 \\
114.7 \\
\\
0.25 \\
0.25 \\
1.2795 \\
0.3740
\end{array}
$$

Carbon steel - A516 Gr 70

Carbon steel - A516 Gr 70

Incoloy $\$ 00$ (0.95 in.) with

stainless steel foil back ( 0.01 in.)

Carbon steel - A516 Gr 70

Mineral wool -

roof ( 6 in.): shell ( 2 in.)

Roof - mineral wool ( 20 in.)

Shell and floor - refractory brick (13.4 in.)

\section{No specified}

Dry sand ( 2 in.)

Reinforced concrete ( 24 in.)

Compacted local soil ( 36 in.) 
- C'BI included a frecboard of approximately $0.5 \mathrm{~m}$ (1.7 fi), while PDM selected a height of $0.30 \mathrm{~m}(1.0 \mathrm{ft})$. As discussed in the CBI report, the freebonard was included to accommodate liquid movement during an earthquake

- The technical specification called for a height of $122 \mathrm{~m}$ (4 fit) to store the drain down from the receiver and thermal storage systems flowever, PDM included a hegght of only 0 (9) $\mathrm{m}$ $(3 \mathrm{ft})$

- ('BI selected an optimum insulation hickness of $50 \mathrm{~cm}$ (20 in), while PDM used $40 \mathrm{~cm}$ ( 16 iil ). The difference was likely due to different assumptions regarding unit insulation costs, as discussed below under colltal. cosl listimall:

- The PDM design used a steel slip plate at the ring wall and a layer of sand near the foundation center to reduce friction loads due to thermal expansion; the CBI floor at the ring wall rested directly on calcium silicate block insulation

- Under the center of the PDM tank, the foundation consisted of layers of insulating firebrick $\left(320 \mathrm{~mm}\left(12 \frac{\mathrm{L}}{\mathrm{in}}\right)\right)$, foamglas $(510 \mathrm{~mm}(20 \mathrm{in})$.$) , thermal concrete (230 \mathrm{~mm}(9 \mathrm{in}))$, and reinforced concrete $(530 \mathrm{~mm}(21 \mathrm{mi}))$ Cooling air ducts, $75 \mathrm{~mm}(3 \mathrm{in}$ ) wide, passed through the thermal concrete layer to limit the emperature of the reinfored concrete, and native soil beneath the concrete, to acceptable levels

- Inder the center of the ('BI tank, the foundation consisted of at least $12 \mathrm{~m}(4 \mathrm{fi}$ ) of compacted clay aggregate The final thickness was to be determined from a detailed thermal allalysis during final design a foundation cooling system, consistmg of water or fored air pupes localted neat the botfom of the chay, would be provided if the selected insulation thickness did not limil the nathe soil lemperatures to less than loo ( $(212$ li)

- Leaks in the bottom of the Pl)M lank were to be detected by contmuous lengths of temperalture sensituve elements locitted under the top layer of the formglas insulation the clements were installed on a $3 \mathrm{~m}$ by $3 \mathrm{~m}$ ( 10 fi by 10 fi) grid, and would activate when the temperature of any $50 \mathrm{~mm}(2 \mathrm{in}$ ) portion exceeded $480 \mathrm{C}(9(1) \mathrm{F})$

- Leaks in the bottom of the CBI tank were to be detected by rows of equally spaced thermocouples locited in the clay foundation the thermocouples would be installed in conduits to simplify repair or replacement

A review of the ('BI and PDM reports by a tank designer within Bechtel provided the following observations:

- Stainless steel tanks, operating at this size and cemperature and using conventional shell-tofloor joints, should be feasible

- The foundation bearing pressure of $290 \mathrm{kPa}\left(6,000 \mathrm{lb} / \mathrm{ft}^{2}\right)$ on the calcium silicate and foam glass was at the upper end of conventional practice 
- The bricks in the ring wall may be subject to settlement, which could lead to stress gradients in the tank bottom. The recommended approach would substitute light weight refractory concrete for the bricks

- The sand in contact with the tank bottom in the PIDM design would need to be free of chlorides

\section{Intemally lnsulated Tink}

The Technigaz concept was quite different from the CBI and PDM approaches. The design was based on the criteria that 1) stainless steel tanks are quite expensive, 2) the joint where the wall meets the floor is sensitive to fatigue failure, and 3) there may be a need during the life of the plant to rapidly transfer salt from the cold tank to the hot tank. To satisfy these criteria, the following approach was used.

- The pressure boundary (lloor, wall, and roof) was fabricated from carbon steel

- A high temperature refractory lining was installed inside the carbon steel tank to transfer hydrostatic loads to the pressure boundary and to provide sufficient resistance to conduction heat transfer such that the carbon steel temperature did not exceed $370 \mathrm{C}(700 \mathrm{~F})$. The lining consisted of 512,000 bricks, ench $23 \mathrm{~cm}$ by $11.5 \mathrm{~cm}$ by $6.5 \mathrm{~cm}$ (9) in $\times 4 \frac{1}{2} \mathrm{in} \times 2 \frac{1}{2} \mathrm{in}$ )

- A corrugated lacoloy 800 liner, $127 \mathrm{~mm}$ (0) (05 in) ) hick, was installed inside the refractory to ssolate the refractory from the corrosive effects of intrate salt at $566 \mathrm{C}(1,0.50 \mathrm{~F})$. The liner also prevented salt migration into cracks in the refractory which could result in local high cemperature areas on the earbon sted shell. The corrugations, illustrated in Figure 3-4, allowed the liner to expand and contract, thus ensuring that all of the hydrostatic loads are transferred through the liner to the refractory bricks the liner flexibility also accommodated rapid temperature tamsients whth monmum lathgue damage the liner concept was originally developed for licpufied natural gas storage tanks and has been suecessfully used III 15 ships and 20 shore installatlons over the past 20 years the concept was extended to high temperature mutrate salt storage by Martun Marietta Corporation and successfully tested in the $7 \mathrm{MWh}$ thermal storage system Subsystem Research Experiment at Sandia National Laboratories

- A stamless sted foil barrier, 025 mmm (0) (0) in ) llack, was installed between the Incoloy laner and the refactory to prevent abrasion of the refractory during thermal transients

- An insulated concrete foundation, cooled by an anray of water pipes, was used to limit the carbon steel floor temperature $10.370 \mathrm{C}(700 \mathrm{f})$ or less lleat from the foundation was rejected to the atmosphere by a $350 \mathrm{kWI}(1,200,000 \mathrm{Btw} / \mathrm{hr})$ wet, mechanical draft cooling tower

- A suspended ceiling, fabricated from corrugated liner material and backed by $50 \mathrm{~cm}$ (20 in ) of mineral wool insulation, was installed inside the tank. The support structure for the ceiling recuired 29 tons of stainless sted members 
- Mineral wool external insulation, $5 \mathrm{~cm}(2 \mathrm{in}$ ) thick on the wall and $15 \mathrm{~cm}$ (6 in) thick on the roof, limited the heat loss from the carbon steel shell

- Any leaks through the lncoloy liner are to be defected by a system consisting of a gas chromatograph, 12 circuits of $12 \mathrm{~mm}$ ('2 in ) stainless sted lubing locited behond the liner corrugations, 12 solenoid valves, a vacuum pump, and a data acquisttion computer (ias samples are continuously taken from each of the circuits in succession should a leak develop, the chromatograph will identify nitrates in the sample gas and the computer will record the location and rate of change in the mitrate concentration

The Technigaz design had only one feature in common with the ( $B$ and PIDN designs, the tank wall and floor thicknesses are essemllally the same as the corresponding thicknesses in the stainless sted tanks. In all other respects, the fwo approaches were quite different, as described below

- The height and diameter of the alelise sill velume in the lechmgale design was $836 \mathrm{~m}(274$

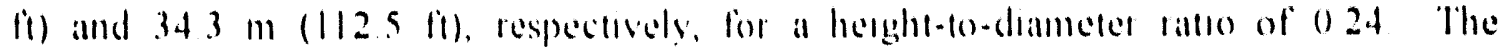
corresponding domensions in the ( 131 and PI)M designs were approximately 13 if 11 (4t 1 fi) and $290 \mathrm{~m}(950$ (f), for all aspect ratto of $(0.46$

- To accommodate the $3.40 \mathrm{~mm}(13+\mathrm{in})$ hinck intemal refractory insulation on the walls and floor, and the $5(0) \mathrm{mm}(20 \mathrm{in}$ ) thick internal mineral wool insulation in the suspended ceiling, the surface area of the carbon steel outer tank must be 111 percent of the surface area of the Incoloy liner

- The temperature gradient through the mineral wool exteror msulation was approxmately

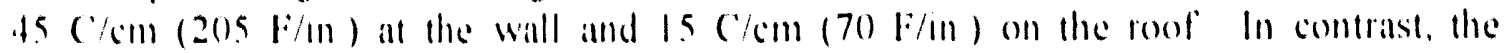
cemperature gradent through the wall and roof insulatton in the ( 131 design was $10(\mathrm{c} / \mathrm{cm}$ $(45 \mathrm{~F} / \mathrm{/n})$ and through the PloM insulation, $13(\mathrm{~cm}$ (60) $\mathrm{F} / \mathrm{m})$ The higher gradents through

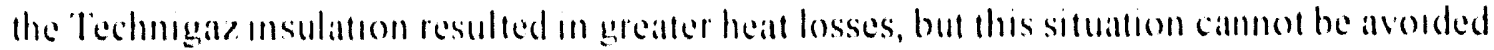
(ireater msulation thicknesses will result in carbon sted shell temperatures whach exced the design value of 288 ( $(550)$

- ()n a similar basis, the lechungaz foundation required an active conlang system lo prevent

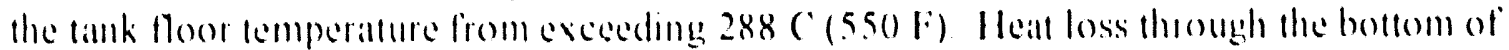

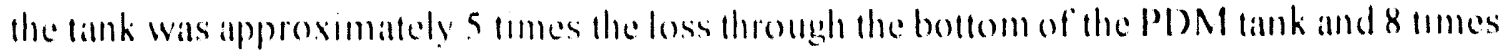
the loss through the ('Bl tank

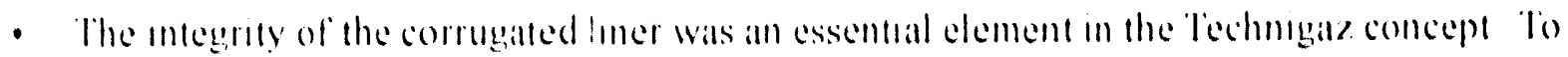
ensure that leaks were identified at yuckly as possible, an actue leak detection system was reguired In contrast, leaks were detected passively in the ( $B$ I and PI)M designs 


\section{THERMIA, LOSSES AND TRANSIENT PERFORMANCE}

One of the principal features cited for the internally insulated tank is its ability to accommodate laphd comperature transients, and thereby avoid the use of heat tracing for mantainung constant temperatures during overnight or extended shutdowns However, the importance of this fealure is perhaps mitigated by two observations

First, Iransient thermal storage tank models developed by Sandia National Laboratories predict that all empty hot salt tank will cool overnight at a rate of I C (2 F) per hour. The following morning. as salt from the recenver is introduced into the tank at an average temperature of $454 \mathrm{C}(850 \mathrm{~F})$, the lank will inmlially cool at a rate of $55 \mathrm{C}(100 \mathrm{~F})$ per hour. During the next 30 minutes, the femperature of the salt from the receiver will increase to the normal outlet value of $566 \mathrm{C}(1,050 \mathrm{~F})$ (nnce this temperature is reached, the tank will heat at a rate of approximately $22 \mathrm{C}(40 \mathrm{~F})$ per hour Discussions with CBI and PDM indicate that large tanks can routinely tolerate temperature ramp rates up to 56 ( $(100$ F) per hour without suffering excessive creep or futigue damage In addition. ramp rates greater than this may also be acceptable, but a detailed thermal stress and fatigue damage atlalysis would be regured to verify the operating procedures Representative experience with large, extemally insulated tanks which tolerate temperature transients at least as severe than those anticipalted for a commercial solar project can al so be found. For example, the thermal storage tanks for the SL: is I parabolic trough solar power plant are $21 \mathrm{~m}(70 \mathrm{ft}$ ) in diameter and routinely accommodate temperature change rates of 40 to 55 ( $(75$ to $100 \mathrm{~F})$ per hour. In addition, a nitrate salt tank $1.4 \mathrm{~m}$ ( $45 \mathrm{ft})$ in diancer fabricaled by ( 131 for a proprietary chemical process plant in Texas mormally operates at $200(\mathrm{C}(5)(0) \mathrm{F})$, but is periodically filled very quickly with salt at $4.50 \mathrm{C}(842$ (F)

It call be noted that the transent performance noted above applies to tanks with conventional shell. fo-floor founts, in wheh the vertical shell is jomed to the horizontal floor by a full penetration weld Prelimmary creep-fatigue calculations by CBI using ASME Code Case N-47 show the joint stresses 10 be lully consistent with a 30 year life However, if a detailed transient thermal and structural analysss shows that thes is not the case, an alternate design is available the alternate uses floor-toshell wamsilnon jomts with a douhle curvature, commonly referred to as "knuckles", which eliminate the orthegenal cormer the vertecal radous of the foumt is approximately $09 \mathrm{~m}(3 \mathrm{ft})$ and the

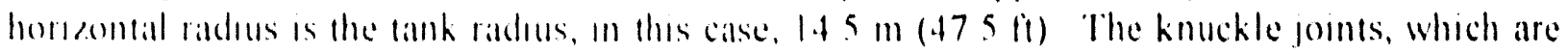
formed whth a large press and dee, are often used in the shell-to-roof jomts of large petroleum and water tanks thes jomt is estmmated to merease the price of the tank by only 3 to 5 percent, and may

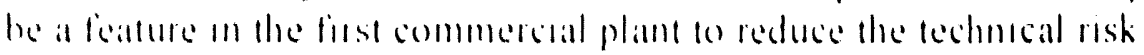

Sicond, heall losses for externally insulated lanks are considerably less than for the internally Imsulated design as shown m Table ot-3 The losses for the (BI and PDM designs are comparable, whth lower values for the ( 131 design likely due to differences in the insulation thickness (5) cm (20)

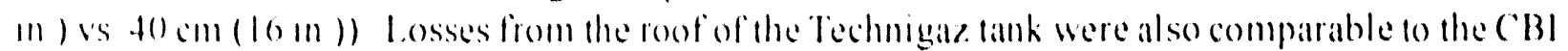
and PI)M roots Thes can be traced to the similar msulation materals and thicknesses on all three tanks However, losses from the Techntgak wall and foundation were signtficantly greater than the correspondeng losses from the externally insulated lanks lhas cin be traced diectly to the relatively high thermal conducenvity of the refractory breks and the need to mantan the carbon sted shell cemperature at or below $260\left(\begin{array}{c}0 \\ (550) \mathrm{H})\end{array}\right.$ 
Table 4-3

COMPARISON OF HOT SALT TANK THERMAL LOSSES

Chicago Bridge and Iron Pitt-Des Moines Technigaz

$\begin{array}{lrrr}\text { Roof } & 73.8 & 95.1 & 65.5 \\ \text { Wall } & 129.0 & 155.4 & 311.5 \\ \text { Floor } & 41.7 & 70.0 & 344.3 \\ & \ldots \ldots \ldots . . & \ldots \ldots . . & \ldots \ldots . . \\ \text { Total } & 244.4 & 320.6 & 721.3\end{array}$

During an extended shutdown, the hot tank will cool to $266 \mathrm{C}(550 \mathrm{~F})$, at which time electric energy is used to maintain the temperature of the inventory. Following the restart of the receiver, the tank may be subject to a rapid change in the temperature of the inventory. Depending on the results of a detailed thermal analysis, the tank and inventory may need to be preheated prior to the restart of the receiver to avoid excessive thermal stresses. If so, the electric energy for preheating should be included in the comparisons of the tank designs. However, the steady state thermal loss from the internally insulated tank is greater than the loss from an externally insulated design. Therefore, some annual quantity of heat tracing for the extermally insulated tank can be used before the annual performance of the two designs is equal. A first order thermal analysis shows the steady state loss from the internally insulated tank to be approximately 2.5 times the average of the thermal losses from the C $B \mathrm{BI}$ and PDM designs. Assuming a Rankine cycle efficiency of 40 percent, the electric heat tracing on the externally insulated tanks could, in theory, be operated continuously and still offer the same annual thermal efficiency as the internally insulated design. Clearly, tank designs refurring such an operating strategy would not be proposed However, it is apparent that the periodic use of trace heating on externally insulated tanks, should it be needed, can be justified.

\section{LEAK REPAIR TIMES}

The vendors were asked to develop procedures and estimated times to repair a leak. The most complete response was provided by Pitt-Des Moines, as follows.

Acuivity

Tank cool down

Tank opening

Leak location

Leak repair

Non-destructive examination

Tank closing

Startup (ambient to $260 \mathrm{C}(500 \mathrm{~F})$ )

\section{Time or Manhours}

24 to 48 hours 40 to 60 manhours

8 to 40 manhours

8 to 32 manhours

4 to 8 manhours

40 to 60 manhours

48 to 72 hours 
To cool the tank within 24 to 48 hours, two holes are opened in the roof and air is circulated through the interior by means of a fan. Air is also forced through the foundation cooling passages to limit the heat transferred from the foundation into the tank. The labor required to locate and repair a leak is estimated to be 100 to 200 manhours. Assuming that the repair crew consists of 2 men, and 3 shifts work each day, the time to complete the repair should be 2 to 4 days. The tank is then brought from ambient temperature to $260 \mathrm{C}(500 \mathrm{~F})$ over the course of 2 to 3 days by means of electric heat tracing. Thus, it appears that a leak could be located and repaired, and the tank filled, in 5 to 9 days.

The Technigaz liner has demonstrated reliable service in numerous liquified natural gas tank installations. However, if a leak should develop in the liner of a nitrate salt tank, it is estimated that the repair procedure would be more lengthy than for an externally insulated tank for two reasons. First, the larger thermal mass of the internally insulated design will extend the cool down period of the tank. A first order analysis was based on the following:

- The weight of the PDM tank was approximately $313,000 \mathrm{~kg}(690,000 \mathrm{lb})$. Assuming a stainless steel specific heat of $460 \mathrm{~J} / \mathrm{kg}-\mathrm{C}\left(0.11 \mathrm{Btu} / \mathrm{lb} \mathrm{m}_{\mathrm{m}}-\mathrm{F}\right)$ and a temperature change of 556 $\mathrm{C}(1,000 \mathrm{~F})$, the thermal mass of the tank was on the order of $22 \mathrm{MWht}$ (76 million Btu). As noted above, the cool down period was 1 to 2 days

- The weight of the Technigaz tank and refractory were $446,000 \mathrm{~kg}(984,000 \mathrm{lb})$ and $1,700,000 \mathrm{~kg}(3,750,000)$, respectively. Assuming a carbon steel specific heat of $460 \mathrm{~J} / \mathrm{kg}-\mathrm{C}$ (0.11 Btu/l $\left.\mathrm{b}_{\mathrm{m}}-\mathrm{F}\right)$, a tank temperature change of $280 \mathrm{C}(500 \mathrm{~F})$, a refractory specific heat of $920 \mathrm{~J} / \mathrm{kg}-\mathrm{C}\left(0.22 \mathrm{Btu} / \mathrm{lb} \mathrm{m}_{\mathrm{m}}-\mathrm{F}\right)$, and a refractory temperature change of $445 \mathrm{C}(800 \mathrm{~F})$, the combined thermal mass of the carbon steel tank and refractory was $210 \mathrm{MWht}(710$ million Btu). Assummg that the cool down period is proportional to the thermal mass, it may take 10 to 20 days following the detection of a leak before repair procedures could be started.

Second, the extent to which the refractory was contaminated with salt would need to be determined and those bricks which had absorbed salt would need to be replaced. The replacement time would depend on the number of contaminated bricks, but it is clear that the leak repair procedure would be more ume consumung than for the externally insulated designs. Thus, it appears that the time required to cool the tank, locate the leak, replace the refractory, and fill the tank could be in the range of 15 to 30 days

From this simple analysis, the frequency of leaks in an internally insulated tank can be only one-half to one-third of that in the externally insulated design without suffering a disadvantage in annual avalability.

\section{ADVANTAGES AND DISADVANTAGES}

Some of the qualitative advantages and disadvantages of each design concept are summarized below in Table $4-4$ 
Table 4-4

STORAGE TANK CONCEPT ADVANTAGES AND DISADVANTAGES

Design
- Structural analysis

- Thermal analysis

Fabrication

Operation

Leak detection

Leak repair

Leak repair time

\section{External Insulation}

More complex fatigue analysis of wall-to-floor joint

Less complex

Less field manhours, but specific weld procedures required for thick stainless steel sections

Temperature ramp rates must be monitored to ensure fatigue life is met; periodic use of heat tracing is acceptable due to lower thermal losses

Passive detection methods suitable to identify shell and bottom leaks

Drain tank, locate by vacuum box, repair leak, and test by vacuum box

5 to 9 days

\section{Internal Insulation}

Less demanding fatigue analysis

More complex, particularly for potential thermal short circuits to carbon steel shell

Significant field manhours and detailed liner weld quality assurance procedures

Rapid thermal transients can be accommodated; 2.5 times higher thermal losses

Active detection methods required to identify liner leaks as quickly as possible

Drain tank, locate by ammonia leak test, repair or replace defective liner section, replace contaminated refractory, and test new welds with ammonia

15 to 30 days 


\section{WARRANTY PROVISIONS}

The principal provisions in the warranty offered by CBI include the following:

- Any defects caused by faulty design, workmanship, or material furnished by CBI will be repaired for a period of one year from the date of completion

- The guarantee is valid only if a complete and continuous temperature and level history of the tank is maintained

- Any warranty of fitness for a particular purpose or compensation for consequential damages are expressly excluded.

Assuming that PDM would design, fabricate, and install the tank on a turn-key basis, PDM would expect to offer its standard commercial warranty as follows:

- Any defects caused by faulty design, workmanship, or material furnished by PDM will be repaired for a period of one year from the date of completion

- Any warranty of fitness for a particular purpose or compensation for consequential damages are expressly excluded.

The scope of work for Technigaz on this study included only the development of material quantities for the tank and a cost estimate for the liner and its installation. Bechtel developed the estimate for procurement and installation of the refractory bricks, carbon steel shell, foundation, and insulation. As such, Technigaz was not in a position to offer a warranty on the complete hot tank. However, Technigaz anticipates that the liner will have a service life of 30 years without leaks.

\section{CAPITAL COST ESTIMATES}

The capital cost estimate for each tank consist of two elements: the investment cost for design, procurement, and installation, and the operating cost of reduced plant output due to thermal losses through the insulation. The later element can be converted to an equivalent capital cost to give an overall assessment of the three designs.

\section{Design, Procuement, and Installation Cost Estimates}

Design, procurement, and installation cost estimates for the externally insulated tanks are summarized in Table 4-5. The CBI and PDM estimates of foundation and tank costs are very close; only the insulation costs differ by a significant amount. As shown in Table 4-2, CBI selected an insulation thickness of $50 \mathrm{~cm}(20 \mathrm{in}$.) while PDM selected $40 \mathrm{~cm}(16 \mathrm{in}$.). The differences in the selected optimums can likely be traced to differences in the unit insulation costs assumed by CBI and PDM. 
Table 4-5

COMPARISON OF HOT SALT TANK COST ESTIMATES

DESIGN, PROCUREMENT,

Chicage Bridge and Iron

Pitt-Des Moines

Technigaz

AND INSTALLATION COST

- Foundation

- Foundation cooling system

- Tank

- Liner

- Heat tracing

- Insulation

Internal

External

- Leak detection system

- Sales tax (7.5 percent)

- Engineering

- Contingency

Total

$\$ 450,000$
Included with foundation
$\$ 2,750,000$
Not required
Not included

Not required
$\$ 500,000$
Not included
Included
Included
Included
$\ldots . . . . . . .$.
$\$ 3,700,000$

$\$ 280,000$
Included with foundation
$\$ 2,840,000$
Not required
Included

Not required
$\$ 1,360,000$
Integral with foundation
$\$ 210,000$
$\$ 320,000$
Included
$\cdots-2, \ldots$
$\$ 5,010,000$

$\$ 470,000$

$\$ 400,000$

$\$ 950,000$

$\$ 4,690,000$

$\$ 260,000$

$\$ 1,100,000$

$\$ 580,000$

$\$ 150,000$

$\$ 210,000$

$\$ 620,000$

$\$ 940,000$

$\$ 10,370,000$

\section{OPERATING COST}

1) Thermal loss, $\mathrm{kWt}$

Roof

73.8

95.1

129.0

155.4

65.5

Wall

41.7

70.0

311.5

Floor

244.4

320.6

344.3

Total

$\$ 44,000$
$\$ 420,000$

Not applicable

Not applicable

$\$ 4,120,000$
$\$ 57,000$

$\$ 540,000$

Not applicable

Not applicable

$\$ 5,550,000$

$\$ 11,670,000$

1) Based on thermal energy cost of $\$ 0.0204 / \mathrm{kWht}$ and annual operating time of 8760 hours

2) Based on levelized capital carrying charge (fixed charge rate) of 10.5 percent

3) Based on pump demand of $8.0 \mathrm{kWe}$ and annual operating time of 8760 hours

4) Based on electric energy cost of $\$ 0.11 / \mathrm{kWhe}$ and levelized capital carrying charge (fixed charge rate) of 10.5 percent 
It should be noted that the CBI estimate does not include heat tracing or a leak detection system, while the PDM estimate includes these items. Thus, the difference in estimates will be somewhat less than shown in the table. Nonetheless, it is encouraging that the two cost estimates, and warranty provisions, are as comparable as they are for this implies that storage tanks for the early commercial plants should be available on a competitive basis

As noted above, Technigaz developed material quantities for the thermal storage tank, but cost estimates only for the liner and installation. Bechtel was responsible for developing the estimate for the procurement and installation of the complete tank. An estimate summary is shown in Table 4-5, and the details of the estimate are presented in Table 4-6. The basis for the estimate included the following:

- All costs were first quarter 1993 dollars

- Equipment and bulk material prices were based on recent Bechtel construction experience and vendor catalog prices

- Labor costs were based on Barstow, California craft wage rates and labor productivity. The wage rates included fringe benefits, taxes, insurance, and a casual overtime allowance of 5 percent. Sufficient labor was assumed to be available in the immediate area, and therefore, no allowance for travel and subsistence was provided

- Distributable labor and material costs were estimated to be 80 percent of direct labor costs These costs included the following:

- Temporary construction building, utility systems, and scaffolding

- Construction equipment, small tools, equipment maintenance, material handling, consumable supplies, and purchased utilities

- Crane, earth mover, and truck rentals

- Field staff providing craft supervision, personnel activities, and warehousing

- In the PDM estimate, engineering costs were approximately 7 percent of the sum of the material and labor costs. For the purposes of this study, engineering costs for the Technigaz design were also estimated to be 7 percent of the sum of the material and labor costs

- The conceptual tank designs outlined in the vendor reports did not include all of the detail which would be available at the completion of final design. To account for items in the cost estimate which were not yet identified, a contingency was added. It was assumed that these contingencies were included in the CBI and PDM estimates. It was further assumed that the level of definition in the Technigaz design is reasonably complete, and that a contingency of 15 percent was sufficient to account for all material and labor costs which have yet to be identified. 
Table 4-6

TECHNIGAZ HOT SALT TANK COST ESTIMATE DETAILS

\begin{tabular}{|c|c|c|c|}
\hline & DESCRIPIION & OTY & UNIT \\
\hline FOUNDATION & & & \\
\hline Excavation & & 500 & Y D3 \\
\hline Fine grade & & 13.300 & $\mathrm{FI} 2$ \\
\hline Formwork & & 800 & FT2 \\
\hline Concrete & & 840 & YD3 \\
\hline Reinforcing steel & & 204 & $\mathrm{~T}$ \\
\hline Embedded metal & & 750 & LB \\
\hline Compacted hackfill & & so & YD3 \\
\hline
\end{tabular}

2.0 FOUNDATION COOLING SYSTEM

Cooling water pipe ( 4 in.. Sch 40 , cartoon steel)

Pipe welds ( $20 \mathrm{ft}$ lengths)

Valves -4 in. gate

$$
\begin{aligned}
& -4 \text { in. check } \\
& \text { supports }-4 \text { in. }
\end{aligned}
$$

Pipe supports -4 in.

Instrumentation (25 percent of installed pipe cost)

$\begin{array}{ll} \pm & \text { Pipe trench excavation and backfill ( } 1.000 \mathrm{ft}) \\ \cong & \text { Cooling water pump ( } 40 \mathrm{gpm} .700 \mathrm{ft} \text { tdh. } 10 \mathrm{thp})\end{array}$

Concrete foundation for cooling water pump

Cooling tower (wet. mechancial dratt: $1.200 .000 \mathrm{Btu} / \mathrm{hr}$ )

Concrete foundation for cooling tower

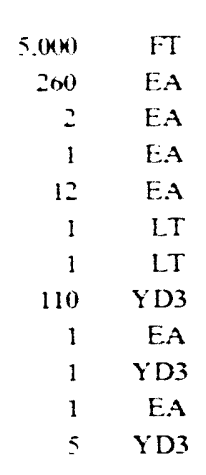

13

2.500

2.000

135

1.500

15.000

15.000

250

250

$\begin{array}{rrrr}463 & \mathrm{~T} & & 1.700 \\ 29 & \mathrm{~T} & 2.500 & 3.000\end{array}$

$512,000 \quad$ EA

2.14
- UNIT TOTAL MHR $\stackrel{\text { MHR }}{-}$

-----------S---------- MATL LABOR SC TOTAL SKC LABOR -

(18.000 T. $\begin{array}{rrr}40 & 0.5 & 250 \\ 40 & 0.03 & 400\end{array}$

$\begin{array}{lll}40 & 0.03 & 400\end{array}$ $40 \quad 1 \quad 840$

800

28.800

$\begin{array}{llll}10 & 2.040 & 122.400 & 146.880\end{array}$

$1.313 \quad 3.780$

3.780
5.760

$----$

$174,913 \quad 292.500$

\section{8,000}

$$
\begin{aligned}
& 40 \\
& 40
\end{aligned}
$$$$
1
$$

80

4,063

\subsection{0}

110.880

269.280

5.093

5,760

$-----$

$40 \quad 0.30 \quad 1500$

64.740

108.000

35.568

172.740

35.568

5.000

2.000

1.620

1.620

40

2871

2,871

7.336

114,854

122.190

30.548

550

40

25

40

100

1.500

1.800

15.000

7.200

$----$

$----$

267.422

250

550

3.300

3.300

22.200

$1.250 \quad 1250$

- $---\quad-.--$

$32.598 \quad 397.216$

3.0 TANK STRUCTURE

Walls, floor and root (A516 Gr. 70 caton steel)

Suspended ceiling ( 316 stainless steel)

4.0 INTERNAL INSULATION

Refractory bricks ( 9 in. $\times 41 / 2$ in. $\times 21 / 2$ in.)

EA

72.500
----
72.500

$787.100 \quad 787.100$

$87.000 \quad 159,500$

$----\quad---.-$

$874,100 \quad 946,600$

$1.095 .000 \quad 1,095,000$

5.0 CORRUGATED LINER

Incolon 800 liner. $1.27 \mathrm{~mm}$ thick

(Includes wall and bottom areas. angke pieces, angle corners.

central piece. bottom caps. flat caps. dog legss. special expansion

bellows between wall and suspended deck. anchor pieces. and 
Table 4-6 (Continued)

TECHNIGAZ HOT SALT TANK COST ESTIMATE DETAILS

$-\frac{\text { DESCRIPIION }}{0.0} \frac{\text { EXTERNAL INSULATION }}{\text { ETION }}$

Walls - mineral wool ( 2 in. thick)

Roof - internal mineral wool ( 20 in. thick)

- external mineral wool (o in. thick)

Aluminum jacket
OTY UNIT

$\begin{array}{ll}15.9(0) & \text { FT2 } \\ 10.300 & \text { FT2 } \\ 10.400 & \text { FT2 } \\ 20.300 & \text { FT2 }\end{array}$

--- UNTT COST ---

MATL

$\mathrm{SC}$ LABOR

UNIT TOTAL

MHR MHR

17
2

28

(Included with insulation cost)

7.0 HEAT TRACING

Mineral insulated resistance cable (150 W/ $/ 1)$

Termination assemblies

Comhination thermostat/contactorjunction box

Mounting brackets

Star connection junction hox

Mounting hrackets

Seals

$\begin{array}{rrr}9.600 & \text { FI } 2 & 13 \\ 28 & \text { EA } & 53 \\ 2 & \text { EA } & 1.050 \\ 2 & \text { EA } & 55 \\ 2 & \text { EA } & 40 \\ 2 & \text { EA } & 55 \\ 28 & \text { EA } & 0.28\end{array}$

$\stackrel{+}{+}$

8.0 LEAK DETECTION SYSTEM

Gas monit oring piping ( $1 / 2$ in. tubing)

Solenoid valves $(1 / 2 \mathrm{in}$.)

Gas chromatograph

Computer ( 80386 with monitor and kentoard)

Data storage ( 300 Megabyte external hard dist: drive)

\section{SUBTOTAL}

Incology liner ocean shipping. import duty. and inland freight Sales tax ( 7.5 percent)

TOTAL

$\begin{array}{rrr}2.000 & \text { FT } & 15 \\ 12 & \text { EA } & 300 \\ 1 & \text { EA } & 8.000 \\ 1 & \text { EA } & 1.500 \\ 1 & \text { EA } & 600\end{array}$

Note: Distributabie costs are estimated to be 80 percent of direct labor costs

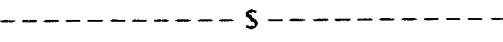
MATL LABOR $\mathrm{STC}$ TOTAL

\section{$270.300 \quad 270.300$} $20.600 \quad 20.600$

582.100

582.100

30
36
30
30
30

$\begin{array}{rr}0.2 & 1 \\ 1 & \\ 5 & \\ 2 & \\ 5 & \\ 2 & \\ 0.02 & \end{array}$

1.920
28
10
4
10
4
1
124.800
1.484
2.100
110
80
$-----$

124.410

1.814
648

259

259

36

$\begin{array}{lll}1.977 & 128,692 & 128,081\end{array}$

249.210

3.298

2.748

309

728

369

4

250.773

123.600

7.056

13.760

4.380

2.040

150,836

150,836

- - - - - - -

$\begin{array}{lllll}46.117 & 2,507,000 & 3.214 .339 & 2.583 .798 & 8.305 .137\end{array}$

285.000

209,400

3.001 .400

$---$

- - - -

- - - 
As expected, the carbon steel vessel in the Technigaz concept was considerably less expensive than the stainless steel vessels recpuired in the CBI and PDM designs. However, in essentially all other categories, the internally insulated design was more expensive. The principal reason for this is the extensive field labor required to install the Incoloy liner and the refractory bricks. Note that the installed cost of just the liner was approximately the same as the complete tank estimates from CBI and PDM. The Technigaz concept was al so burdened with an active foundation cooling system and leak detection system that the other two concepts did not require

\section{Operating Cost Estimutes}

Operating costs included the economic penalty for heat loss through the tank insulation plus, for the Technigaz concept, the penalty for electric energy use in the foundation cooling system. The thermal losses from each tank, shown in Table $4-5$, can be converted to an equivalent capital cost using the following equation

\section{Equivalent Capital Cost $=\frac{\text { Thermal loss } * \text { Marginal thermal energy cost } * \text { Annual operating time }}{\text { Levelized Capital Carrying Charge }}$}

where

- The marginal cost of the collector and receiver system fo supply $1 \mathrm{kWh}$ of thermal energy was estimated to be $\$ 0.020$. This was based on a unit heliostat price of $\$ 175 / \mathrm{m}^{2}$ and a unit receiver system price of $\$ 115 / \mathrm{kW1}$

- The annual operating time of the tank was assumed to be 8,760 hours

- The levelized capital carrying charge (fixed charge rate) was 10.5 percent The rate, based on standard utility project financing and a constant year dollar analysis, was that used during Phase I of the central receiver Utility Studies

A similar analysis was used to convert the annual electric energy demand of the Technigaz foundation cooling water pump to an equivalent capital cost. The pump power demand was a continuous $8 \mathrm{kWe}$. The value of electric energy was assumed to be the levelized energy cost for the first commercial plant in Phase I of the Utility Studies, or $\$ 0.11 / \mathrm{k}$ Whe

The results of the calculations are shown in Table 4-5. For each tank, the equivalent capital cost for operation was equal to approximately 10 percent of the design, procurement, and installation cost Note that the higher heat losses through the Technigaz insulation entailed an economic penalty of approximately $\$ 750,000$ relative to the $C B 1$ and PDM approaches 


\section{Design, Procurement, Installation, and Opernting Cost Estimates}

The sum of the design, fabrication, installation, and operating cost estimates are also shown in Table 4.5. From a review of the estimates, the following observations can be made

- The internally insulated tank is approximately twice as expensive as the externally insulated designs

- There is good agreement on the cost estimates from two of the vendors who are potential suppliers to the Solar Two and early commercial projects

- The subcontract price developed by CBI for the externally insulated hot salt tank and foundation in Phase I of the Utility Studies was $\$ 3,300,000$ (third quarter 1987 dollars). Escalating this price to first quarter 1993 dollars using an annual rate of 4 percent yields an estimate of $\$ 4,100,000$. This price compares very favorably with the average of the CBI and PDM estimates in this study $(\$ 4,350,000)$

- It appears that a hot salt tank for a $100 \mathrm{MWe}$ commercial project can be fabricated and installed for approximately $\$ 5$ million. 


\section{Section 5}

References

1.1 Hillesland, T., Jr., (Pacific Gas and Electric Company, San Ramon, California) "Solar Central Receiver Technology Advancement for Electric Utility Applications, Phase I Topical Report", GM 633022-9, DOE Contract DE-FC04-86AL.38740, and EPRI Contract RP 14781. August 1988

1-2 Hillesland, T,, Jr., (Pacific Gas and Electric Company, San Ramon, California) "Solar Central Receiver Technology Advancement for Electric Utility Applications, Phase IIC Topical Report". Advanced Energy Systems Report 007.25-92 2, DOE Contract DE-FC0486AL.38740, November 1992

1-3 "Status of Solar-Thermal Electric Technology", H. G H. Enterprises, Laguna Hills, California, Electric Power Reseatrch Institute Report GS-6573, Project 2003-9. December 1989

2-1 "Molten Salt Stean Generator Subsystem Research Experiment, Phase I Final Report, Volume 1", Foster Wheeler Solar Development Corporation, Livingston, New Jersey, IWWSDC Contract 9.71-9202, Sandia National Laboratories Report 82-8179, October 1984

2.2 "Molten Salt Steam Cienerator Subsystem Research Experiment Phase 1: Final Report", The Babcock and Wilcox Company, Barberton, Ohio, Sandia National Laboratories Contract 20 90(09A, Sandia National Laboratories Report 82-8177. September 1984

2-3 "Molten Salt Thermal Energy Storage Subsystem Research Experiment - Volume II", Martin Marietta Corporation, Denver, Colorado, DOE Contract DE-AC04-76DP00789, Sandia Nattonal Laboratories Report SAND80-8192, May 1985

2.4 Kolb, (i, (Sanda National l,aboratories, Albucpuereue, New Mexico), "Thermal Cycling of Thermal Energy Storage Tanks Proposed for the Solar Two Central Receiver Power Plant", Paper presented at the 1993 ASMI: International Solar Energy Conference, Washington, 1) C., April 1993 
Appendix A

Statement of Work for Steam Generator Vendors 


\section{Statement of Work \\ Steam Cenerator Design and Cost Estimate}

\section{PURPOSE.}

The purpose of this study is to resolve issues related to the design, fabrication, warranty, and capital cost of steam generator systems for commercial nitrate salt central receiver plants The next central receiver project will be the Solar Two project, a retrofit of the 10 MWe Solar One pilot plant with nitrate salt receiver, thermal storage, and steam generation systems In addition, it is likely that the Solar Two project will be the only predecessor to the first $100 \mathrm{MW}$ commercial project Therefore, the equipment installed at Solar Two should be as representative as possible of the equipment to be installed in the first commercial project To select the best design for the Solar liwo project, an optimum design must be defined for the first $100 \mathrm{MWe}$ project This study will review and compare the alternate steam generator designs for the first $100 \mathrm{MWe}$ project. and evaluate these designs according to their feasibility, capital cost, perfomance, warranty terms, and operattion and maintenance repuirements

\section{BACK(iROUNI)}

The central recelver U/ility Studies completed in 1988 proposed a baselune design for all the major systems in the first commercial foc) NWe plant The steam generator design, developed by Babcock \& Wilcox, was a foreed recirculation drum type with separate shells for the superheater, reheater, evaporator, and preheater the heat exchangers used a $(1-$ bube/(1-shell design, which is highly tolerant of thermal stresses due to transients but is also rather expensive Other steam gentrator designs have been proposed which may be suitable and less expensive, but they have not been investigated in the same level of detail These include the following

- Natural circulation drum typs, with stranght tube/straight shell superheater, reheater, evaporator, and preheater components using bellows for thermal expansion This concept was developed by fositer Whecler in the early 1080's

- Ketlle evaporator with (1-tube/straight shell superheater, reheater, and preheater components Thus design is smimiar to that currently employed by luz in the Slacis vill and IX power plints.

In this study, Foster Wheeler will investlgate the straight tube/stranght shell design, and $A B B$ l.ummus and Struthers Wells the kettle evaporator concept

\section{S'TEAM GENERATOR SCOPE OF SUPPIN}

The steam generator transfers the thermal energy in matrate salt to thermal energy in main and reheat steam for use in a turbine-gencrator the steam generator includes the following items:

- Nitrate salt-to-water and nitrate salt-10-steam heat exchangers

- Steam drum, if recuired 
- Nitrate salt and steam attemperators, as required

- Inter-hent exchanger piping

- Water recirculation pumps, if required

- Electric heat tracing and insulation

- Heat exchanger and piping supports

- Controls and instrumentation

Performance specifications for the steam generator are summarized in Table A-1. In sizing the heal exchangers, consideration shall be given to optimizing the heat transfer area and salt side pressure drop) For this study, the value (ecpuivalent capital cost) of reducing the pressure drop on the salt side by 1 fit of head is estlmated to be $\$ 9,000$

\section{STATEMIENT OF WORK}

The vendor shall review and update the existung steam genterator design, describe the advantages and disadvantages of the heat exchanger configuration, and provide an updated capital cost estimate specific ilems to be addressed include the following

- Heat exchanger arrangement drawings, and section drawings which are representative of the components

- Hear exchanger specilicallons, moludang

- matterials

- hear transfor areas

- tube and shell side heat transfer coefficients

- weights of the shell and internals

- Regurements for salt temperature attemperation at the mlet to the superheater, reheater, or eviporator

- Design, fabrication, and delasery schedule

- Fistmatled stant umes from cold, warm, and hot conditions

- Overnight hemal condithoning reguirements and the ability to respond to daily temperature transients

- Warranty provisions 
Table A.1

STEAM GENERATOR PERFORMANCE SPECIFICATION

Nominal Ratings $\quad 110 \mathrm{MWe}$ gross plant output

260) MW' steam generator duty

Final Feedwater $\quad 236(4.56 \mathrm{~F})$

(As required) MPa (psia)

$93.71 \mathrm{~kg} / \mathrm{sec}(743,700 \mathrm{lb} / \mathrm{hr}) ; 1 \%$ blowdown assumed

Main Stean

$540 \mathrm{C}(1,004 \mathrm{~F})$

$13.03 \mathrm{MPa}(1,890 \mathrm{psia})$

$92.77 \mathrm{~kg} / \mathrm{sec}(736,300 \mathrm{lb} / \mathrm{hr})$

Cold Reheat Steam $347 \mathrm{C}(656 \mathrm{~F})$

$3.08 \mathrm{MPa}$ (446 psia)

$79.92 \mathrm{~kg} / \mathrm{sec}(634,300 \mathrm{lb} / \mathrm{hr})$

Hot Reheat Steam

$538(1,000 \mathrm{~F})$

$277 \mathrm{MPa}(402 \mathrm{psia})$

$7902 \mathrm{~kg} / \mathrm{sec}(6.34,300 \mathrm{lb} / \mathrm{hr})$

Nitrate Salt

$566 \mathrm{C}(1,050 \mathrm{~F})$ inlet temperature (As recpured) MPa (psia) inlet pressure

$454(8.50$ l.) maximum evaporator lube temperalure consistent with acceptable corrosion rates for chrome-moly lubes

288 ( 1550 ) F) outlet temperature

$138 \mathrm{kPa}(20 \mathrm{psia})$ outlet pressure

Specific heat

$0345+\left(228 \times 10^{9}\right)(\mathrm{Temp}, \mathrm{F}), \mathrm{Btu} / \mathrm{/b} \mathrm{m}_{\mathrm{m}} \mathrm{F}$

Density

$1312-\left(2.221 \times 10^{\circ}\right)(\mathrm{Temp}, \mathrm{F}), 1 \mathrm{~b}_{\mathrm{m}} / \mathrm{ft}^{3}$

Thermal conductivity

() $25308+\left(626984 \times 10^{5}\right)($ Temp, F $)$, Btu/hr-ft-F

Viscosity

$602844 \cdot(0.17236)($ Temp, F $)+\left(1.76176 \times 10^{4}\right)(\text { Temp, F })^{2}$

$-\left(6.11408 \times 10^{. x}\right)\left(\right.$ Temp, F $^{3}, \mathrm{Ib}_{\mathrm{m}} / \mathrm{ft}-\mathrm{hr}$ 
- Cost breakdown in sufficient detail to understand how the costs were developed and to permit a comparison with costs from the other vendors. The breakdown should include the following items:

- Engineering and procurement

- Material costs for each heat exchanger and the steam drum (if required)

- Fabrication costs for each heat exchanger and the steam drum (if required)

- Installation

- Heat tracing and insulation

- Controls and instrumentation. 
Appendix B

Statement of Work for Thermal Storage System Hot Salt Tank Vendors 


\section{Statement of Work \\ Hot Salt Tank Design Cost Estimate}

\section{PURPOSE}

The purpose of this study is to resolve issues related to the design, fabrication, warranty, and capital cost of thermal storage systems for commercial nitrate salt central receiver solar power plants. The next central receiver project will be the Solar Two project; a retrofit of the $10 \mathrm{MWe}$ Solar One pilot plant with nitrate salt receiver, thermal storage, and steam generation systems. In addition, it is likely that the Solar Two project will be the only predecessor to the first 100 MWe commercial project, and therefore, the equipment installed at Solar Two should be as representative as possible of the equipment installed in the first commercial project. To select the best design for the Solar Two project, an optimal design must be defined for the first 100 MWe project. This study will review and compare the alternate thermal storage tank designs for the first $100 \mathrm{MWe}$ project, and evaluate the designs according to their feasibility, capital cost, and warranty terms.

\section{BACKGROUND}

The central receiver Utility Studies completed in 1988 proposed a baseline design for all of the major systems in the first commercial $100 \mathrm{MWe}$ plant. An externally insulated carbon steel tank was used to store the $550^{\circ} \mathrm{F}$ cold salt and an externally insulated stainless steel tank was used to store the $1050^{\circ} \mathrm{F}$ hot salt. Designs and costs for these tanks were provided by $\mathrm{CBI}$ Industries and by Pitt-Des Moines.

Earlier studies of Martin Marietta adopted an alternate hot salt tank design based on use of an internally insulated carbon steel tank with an inner waffle-configured stainless steel liner developed by Technigaz. A $7 \mathrm{MWh} 1050^{\circ} \mathrm{F}$ salt tank based on this concept was installed and successfully tested at the Sandia Central Receiver Test Facility at Albuquerque in 1982.

This study is intended to assess the relative feasibility, warranty availability, and capital cost for these two hot salt tank design approaches. Bechtel will compare and evaluate information supplied by Pitt-Des Moines, CBI Industries and Technigaz to determine which designs are suitable for 1050 " F service in a $100 \mathrm{MWe}$ central receiver solar power plant.

\section{HOT SALT THERMAL STORAGE TANK SCOPE OF SUPPLY}

The hot salt thermal storage tank stores heated salt from the solar receiver until it is pumped to the steam generator for subsequent conversion to electric energy. The thermal storage tank includes the following items:

A stainless steel or carbon steel tank

An exterior or interior insulation system 
A stainless steel liner (only for interior insulation system)

A cooled foundation

A leak detection system (not a part of Task 4 cost estimate)

An electrical heat tracing system capable of preheating the empty tank prior to in itial charging of tank with salt (not a part of Task 4 cost estimate).

The specification for the hot salt thermal storage tank is presented in Table B-1. It is based on the tank specification from the Utility Studies, with the requirement for a leak detection system added.

\section{STATEMENT OF WORK}

\section{Task 1 Design Review hid Update}

The vendor shall review their previous tank designs that were prepared for the Utility Studies (PDM and CBI) or for the thermal energy storage tank design reported in "Molten Salt Thermal Energy Storage Subsystem Research Experiment", MCR-82-1722, September 1982 (Technigaz). The latter design shall be scaled as needed to satisfy the capacity and other requirements of the Table B-I specification. Each vendor can make modifications as may be necessary to bring the design in step with the current technology status.

Deliverables Description of updated tank design including a discussion of prominent tank design features and associated advantages and disadvantages with illustrations and/or drawings.

\section{Task 2 Inputs for Tank Design Comparisons}

Criteria for the tank design comparisons to be made by Bechtel are indicated below. The vendor shall prepare written discussions of their design covering each of the comparison criteria listed below. Note that two of the criteria are treated in Tasks 3 and 4 and need not be discussed under Task 2 .

- Capital cost (discussed under Task 4)

Fabrication quality assurance

Warranty provisions

Accommodation of thermal expansion and heat tracing

Estimated rate of heat loss

Foundation design concept

Inventory charging and inventory/temperature cycling

Leak detection, location and repair (discussed under Task 3)

Major maintenance repair anticipated during a 30-year service life.

Areas of design uncertainty and recommended resolution

Deliverables Written discussions of comparison criteria 
Table B-1

HOT SALT TANK SPECIFICATION

Active Tank Volume

Additional Tank Volume

Tank Heel

Draindown Volume

Tank Freeboard

Equivalent Capital Cost per kWt

of Heat Loss (for use in calculating optimal insulation thickness)

Insulation Shield Temperature

Heat Tracing System

Bottom Leak Detection System

Cooled Foundation

Seismic

Wind

Allowable Soil Bearing Capacity

Density of Salt
$7,693 \mathrm{~m}^{3} \quad\left(271,674 \mathrm{ft}^{3}\right)$

$\left(1,560 \mathrm{MW}^{\prime} \mathrm{h}\right.$ in $550 \mathrm{~F}$ to $1,050 \mathrm{~F}$ salt $)$

See Figure B-1

$0.914 \mathrm{~m}(3 \mathrm{ft})$

$1.219 \mathrm{~m}(4 \mathrm{ft})$

To allow for draining of receiver inventory and for emergency storage of cold tank heel

(To be selected by supplier)

$\$ 1700 / \mathrm{kWt}$

$140^{\circ} \mathrm{F}$ Maximum

Electric heating elements to be utilized at $50 \%$ of rating; redundant circuits are required

(Vendor concept and design)

(Vendor concept and design)

API 650, Zone 3

$90 \mathrm{mph}$ (1) $10 \mathrm{~m}$ above grade

5,000 psf (a) $5 \mathrm{ft}$ below grade 10,000 psf (d) $10 \mathrm{ft}$ below grade

$131.2-\left.0.0222\right|^{*}\left(\right.$ Temp, $\left.{ }^{\circ} \mathrm{F}\right), \mathrm{Ib}_{\mathrm{m}} / \mathrm{ft}^{3}$ 


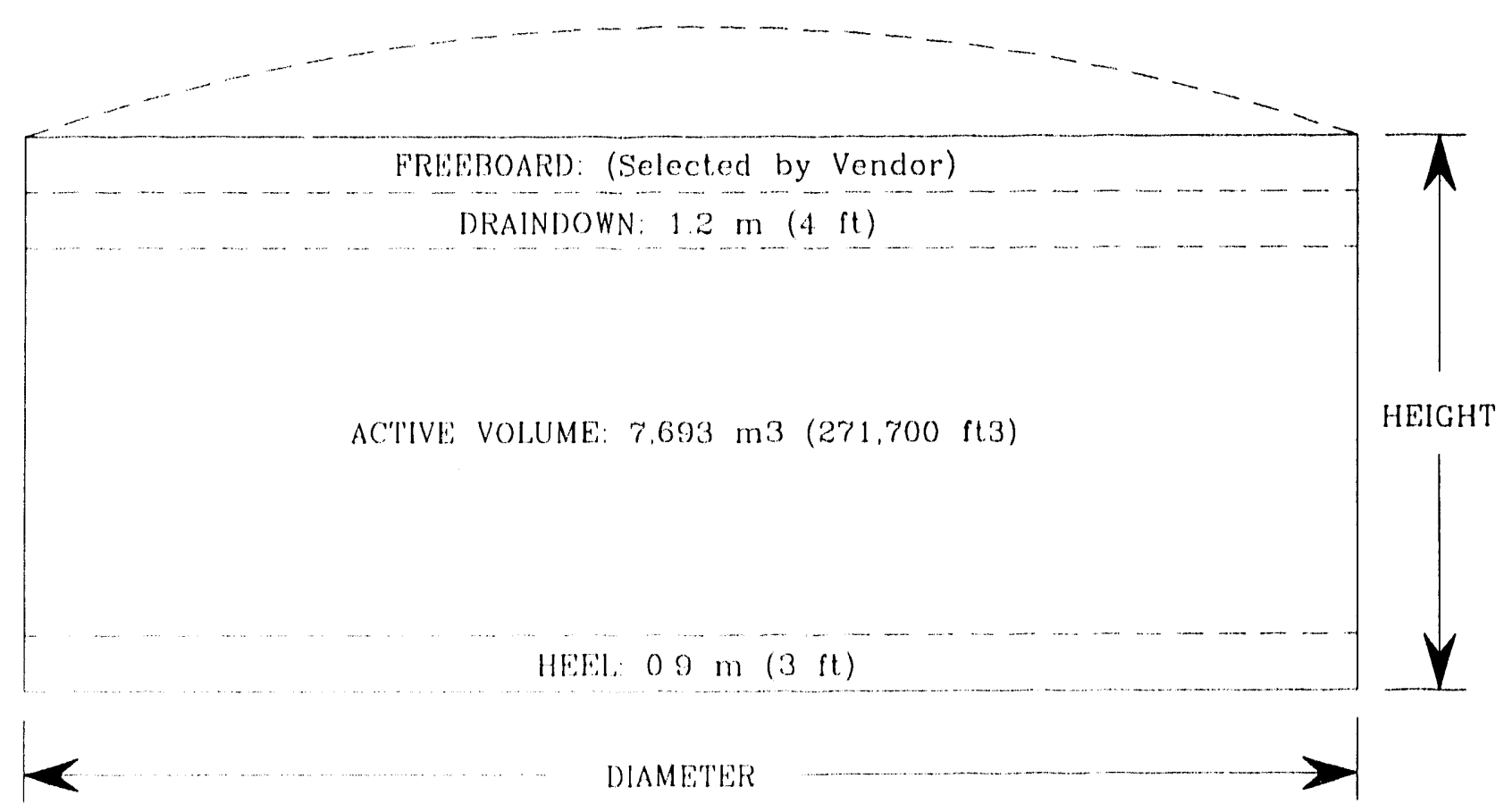

TANK VOLIIME AC"TIVL: VOL,LME + HEEL + DRAINDOWN + FREEBOARD

Figure B l thermal Storage Tank Nomenclature 


\section{Task 3 Repair Rationale}

We assume that a tank leak will occur at least once during the 30 year life of the plant. The vendor shall provide a discussion of the rationale for leak detection, location and repair. Items to be addressed shall include:

Recommended leak detection rationales and equipment

- Methods for locating a tank bottom leak and baseline estimate of the required time

- Tank bottom leak repair procedure and baseline estimate of required completion time

- Representative range of labor hours to locate and repair a tank bottom leak (with uncertainties duly noted).

\section{Deliverables Written repair rationale}

\section{Task 4 Cost Estimates}

The vendor shall prepare an estimate of installed cost of the hot salt tank, covering the entire scope of supply indicated on pages 1 and 2 above except as noted below. Estimated costs shall identify engineering and procurement, tank materials, insulation materials, foundation materials and field fabrication costs in sufficient detail to permit a comparison with cost from other vendors. Heat tracing system and leak detection system costs are not required. Site location is assumed to be Barstow, California. Uncertainties associated with selected elements of the cost estimate should be duly noted.

Estimates in foreign currency should include an approximate estimate of that portion of the materials and of the labor that may become available from United States sources.

Deliverables Cost estimates 
U.S. Department of Energy (3) Forrestal Building

Code EE-132

1000 Independence Avenue, SW

Washington, DC 20585

Attn: Gary D. Burch

N. Haque

S. Gronich

U.S. Department of Energy

Golden Field Office

1617 Cole Boulevard

Golden, CO 80401

Attn: Bob Martin Project Manager John W. Meeker Contract Specialist

Advanced Thermal Systems 7600 East Arapahoe

Suite 319

Englewood, CO 80112

Altn: D. Gorman

Arizona Public Service Company

P. O. Box 53999, MS 1424

Phoenix, AZ 85072-3999

Alln: Scolt McLellan

Joe McGirk

Asinel

Francisco Gervals, 3

Madrid 28020, SPAIN

Attn: Jesus M. Mateos

Atlantis Energy Lid.

Thunstrasse 43a

300.5 Bern, SWITZERLAND

Attn: Mario Posnansky

Babcock and Wilcox

91 Stirling Avenue

Barberton, OH 44203

Altn: P. A. Bator

Battelle Pacific Northwest

Laboratory

P.O. Box 999

Richland, WA 99352

Altn: D. Brown

Kevin Drost
Bechtel National, Inc. (3)

50 Beale Street

50/15 D8

P. O. Box 193965

San Francisco, CA 94119-3965

Altn:

P. DeLaquil

B. Kelly

R. Lessley

Black \& Veatch

Consulting Engineers

P.O. Box 8405

Kansas City, MO 64114

Attn: Larry Stoddard

Tom Brumleve

1512 Northgate Road

Walnut Creek, CA 94598

Bureau of Reclamation

Code D-3710

P. O. Box 2050)7

Denver, CO 80225

Altn: $\quad$ Stanley Hightower

California Energy Commission 1516 Ninth Street, M-S 43

Sacramento, CA 95814

Altn: A. Jenkins

California Public Utilities Com. Resource Branch, Room 5198 455 Golden Gate Avenue San Francisco, CA 94102
Altn:
T. Thompson

Central and South West Services Mail Stop 7RES

1616 Woodall Rogers Freeway

Dallas, TX 75202

Attn: $\quad$ Edward L Gastineau

Centro Investigations Energetica (2)

Medroansental Technologie (CIEMAT)

Avda. Complutense, 22

28040 Madrid, SPAIN

Attn: M. Macias

M. Romero

Conphoebus

Sede Leg.

Via G. Leopardi, 60

95127 Catania, ITALY

Attn: Gino Beer 
DFVIR, HA-ET

Linder Hoche

P. O. Box 9060 58

$50(0)$ Cologne 90 , GERMANY

Altn: $\quad$ M. Becker

M. Bochmer

Daggetl Leasing Corporation

35100 Sinta Fe Street

P. O. Box 373

Daggell, CA 92327

Attn: Wayne Lutton

EIR

CH-5303 Wurenlingen, SWITZERL.AND

Attn: W. Durish

Electric Power Rescarch Institute

3412 Hillview Avenue

P.O. Box 10412

Palo Alto, CA 94303

Altn:

E. DeMeo

D. Morris

Foster Wheeler Solar Development

Corporation

12 Peach Tree Hill Road

Livingston, NJ 07039)

Altn: $\quad$ S. F. Wu

Hans W. Fricker

Breitestr. \#22

CH 8544 Rickenbach, SWITZERLAND

Georgia Power

7 Solar Circle

Shenandoah, GA 30265

Altn: Ed Ney

Dick Holl, President

Jenna Baskets

2475 Coral Street, Suite D

Vista, CA 92083

Idaho Power

P. O. Box 70

Boise, ID $837(07$

Attn: Jerry Young

John Prescott

Interatom $\mathrm{GmbH}$

P. O. Box

D-5060 Bergisch-Gladbach, GERMANY

Altn: M. Kiera
KJC Operating Company

41100 Highwayl 395

Boron, CA 93516

Alln: Dave Ochenrider

S. Frier

Kearney \& Associates

14022 Condessa Drive

Del Mar, CA 92014

Altn: David W. Kearney

Lawrence Berkeley Laboratory

MS 90)-2024

One Cyclotron Road

Berkeley, CA 94720

Altn: $\quad$ Arlon Hunt

Los Angeles Department of Water and Power

Alternate Energy Systems

Room 66IA

111 North Hope Street

Los Angeles, $\mathrm{CA} 90012$

Alun: Darryl Yonamine

Augi Garcia

Peter Lynch

Pacific Power

Park and Elizabeth Streets

GPO Box 5257, Sydney

New South Wales 2001 Australia

National Renewable Energy Lab (5)

1617 Cole Boulevard

Golden, CO 8040)

Altn:

Tom Williams

Mark Bohn

Nevada Power Co.

P. O. Box 230)

Las Vegas, NV 89151

Altn: Mark Shank

Palcific Gas \& Electric

3400 Crow Canyon Road

San Ramon, CA 94.583

Altn: Ray Dracker

Chris Haslund

Pasadena Waler and Power Division 150) South Los Robles Avenue

Suite 2())

Pasadena, CA 91101

Alun: Manny Robledo 
Platforma Solar de Almerin (2)

Aptdo. 22

Tabernas (Almeria)

E-(04200) SPAIN

Altn:

M. Sanchez

W. Grasse

Public Service Co. of New Mexico

$\mathrm{M} / \mathrm{S} 0160$

Alvarado Square

Albuquerque, NM 87158

Attn:

T. Ussery

A. Martine\%.

Rockwell International

Rocketdyne Division

6633 Canoga Avenue

Canoga Park, CA 91303

Allin: M. Marko, MS FA70

E. Baughmesiter

Sacramento Municipal Utilities District P. O. Box 15830)

Sacramento, CA 95852-1830

Altn: Robert Wichert Larry Wittrup

Salt River Project

Research and Development

P. O. Box 52025

Phocenix, AZ. 85072-2025

Allin:

Bob lless

Ernic Palamino

San Diego Gas and Electric Company

P.O. Box 1831

San Diego, CA 92112

Attn: R. Figueroa

\section{SCAQMD}

21865 Copley Drive

Diamond Bar, CA 91765

Altn: $\quad$ Ranji George

Science Applications International

Corporation

2109 Airpark Road, SE

Albuquerque, NM 87106

Altn: D. Smith

Science Applications International

Corporation

$15000)$ W. 6th Avenue, Suite 202

Golden, CO 80401

Altn: Kelly Beninga

Solar Kinctics, Inc.

P.O. Box 540636

Dallas, TX 75354-0636

Alln

J. A. Hutchison

Solar Power Engineering Company

P.O. Box 91

Morrison, CO 80465

Altn: H. C. Wroton

Southern California Edison

2244 Walnut Grove Avenue

P. O. Box 800

Rosemead, CA 91770)

Altn:

C. Lopez

I. Katter

M. Skowronski

Tom Tracey

6922 South Adams Way

Littleton, CO 80122

University of Houston

Solar Energy Laboratory

4800 Calhoun

Houston, TX 777(0)4

Altn: L. Vant-Hull

University of Nevada at las Vegas

Howard R. Hughes Coll of Engineering 4505 Maryland Parkway

Las Vegas, NV 89154-4026

Altn: Robert F. Buelinı

Utah Power

1407 West North Temple

Sall Lake City, UT 84140-0001

Altn: $\quad$ lan Andrews

4521

4526

5371

5609

6200

$62(0)$

6201

6202

6204

6211

6212

6213

6214

6215

6215

6215

6215
J. A. Leonard

Lori Parroll

S. Faas

A. Baker

D. E. Arvizu

D. J. Alpert

P. C. Klimas

G. J. Jones

N. J. Magnani

A. P. Sylwester

H. P. Stephens

T. C. Bickel

H. M. Dodd

C. P. Cameron

M. E. Ralph

E. E. Rush

J. W. Strachan 
J. M. Chavez

(i. J. Kollb

T. R. Mancini

D. F. Menicued

J. E. Pacheco

M. R. Prairic

H. E. Ruilly

D. E. Hasti

M. L. Whipple

7151 Technical Publications

7613.2 Document Processing for DOE/OSTI (10)

8523-2 Central Technical Files 


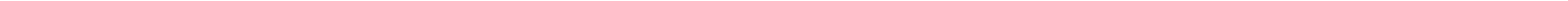



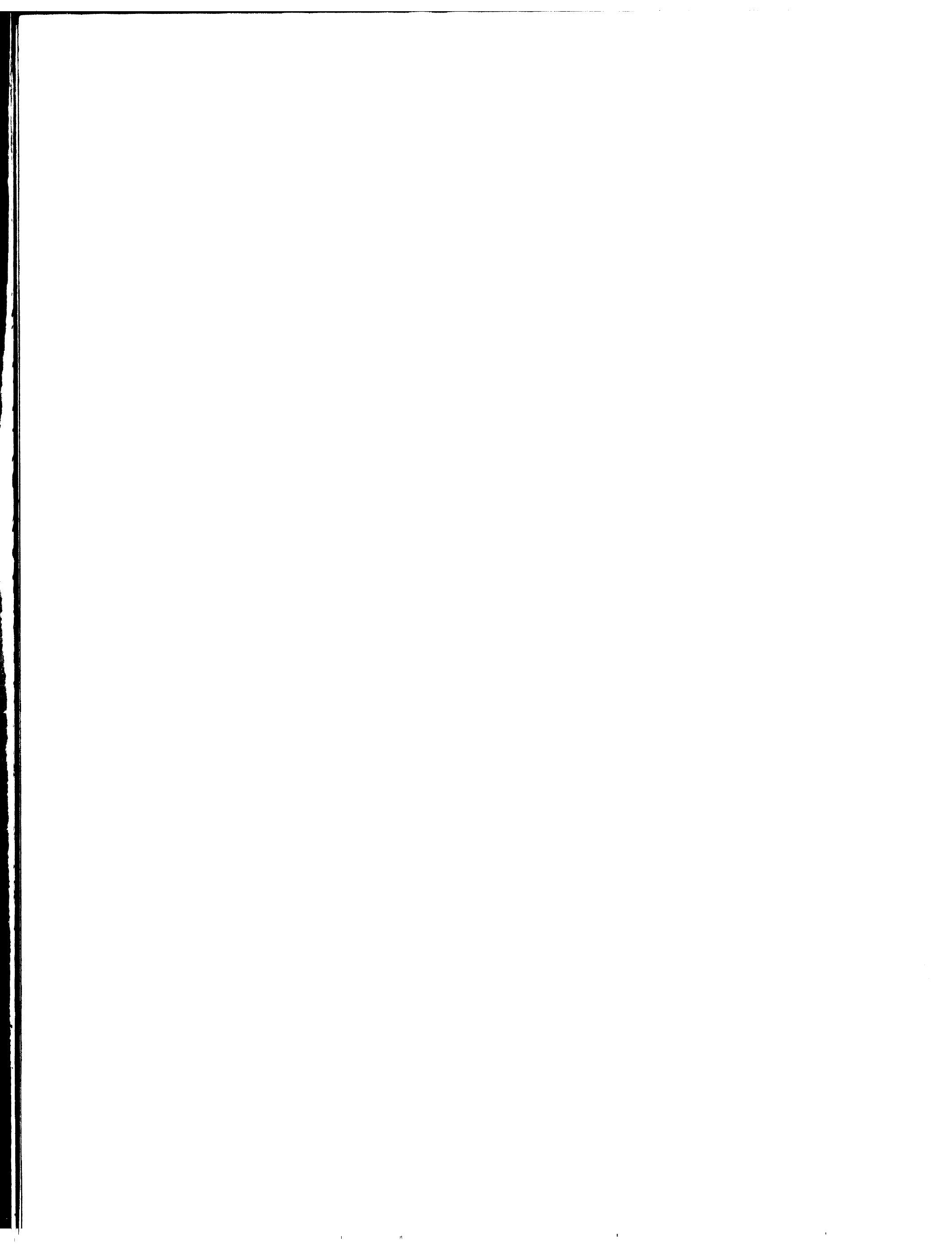